\title{
East Asian monsoon climate during the Late Pleistocene: high-resolution sediment records from the South China Sea
}

\author{
L. Wang ${ }^{\mathrm{a}, *}$, M. Sarnthein ${ }^{\mathrm{a}}$, H. Erlenkeuser ${ }^{\mathrm{b}}$, J. Grimalt $^{\mathrm{c}}$, P. Grootes ${ }^{\mathrm{b}}$, S. Heilig ${ }^{\mathrm{a}, 1}$, \\ E. Ivanova ${ }^{\mathrm{a}, 2}$, M. Kienast ${ }^{\mathrm{a}, 1}$, C. Pelejero ${ }^{\mathrm{c}}$, U. Pflaumann $^{\mathrm{a}}$ \\ ${ }^{a}$ Institute of Geosciences, Kiel University, Kiel, Germany \\ ${ }^{b}$ Leibniz Labor, Kiel Universität, Kiel, Germany \\ ${ }^{c}$ Departament de Quimica Ambiental, Centre D'Investigació i Desenvolupament, \\ Barcelona, Catalonia, Spain
}

Received 21 March 1998; accepted 20 August 1998

\begin{abstract}
Based on the study of 10 sediment cores and 40 core-top samples from the South China Sea (SCS) we obtained proxy records of past changes in East Asian monsoon climate on millennial to bidecadal time scales over the last 220,000 years. Climate proxies such as global sea level, estimates of paleotemperature, salinity, and nutrients in surface water, ventilation of deep water, paleowind strength, freshwater lids, fluvial and/or eolian sediment supply, and sediment winnowing on the sea floor were derived from planktonic and benthic stable-isotope records, the distribution of siliciclastic grain sizes, planktonic foraminifera species, and the $\mathrm{U}_{37}^{\mathrm{K}}$ biomarker index. Four cores were AMS- ${ }^{14} \mathrm{C}$-dated. Two different regimes of monsoon circulation dominated the SCS over the last two glacial cycles, being linked to the minima and maxima of Northern Hemisphere solar insolation. (1) Glacial stages led to a stable estuarine circulation and a strong $\mathrm{O}_{2}$-minimum layer via a closure of the Borneo sea strait. Strong northeast monsoon and cool surface water occurred during winter, in part fed by an inflow from the north tip of Luzon. In contrast, summer temperatures were as high as during interglacials, hence the seasonality was strong. Low wetness in subtropical South China was opposed to large river input from the emerged Sunda shelf, serving as glacial refuge for tropical forest. (2) Interglacials were marked by a strong inflow of warm water via the Borneo sea strait, intense upwelling southeast of Vietnam and continental wetness in China during summer, weaker northeast monsoon and high sea-surface temperatures during winter, i.e. low seasonality. On top of the long-term variations we found millennial- to centennial-scale cold and dry, warm and humid spells during the Holocene, glacial Terminations I and II, and Stage 3. The spells were coeval with published variations in the Indian monsoon and probably, with the cold Heinrich and warm Dansgaard-Oeschger events recorded in Greenland ice cores, thus suggesting global climatic teleconnections. Holocene oscillations in the runoff from South China centered around periodicities of 775 years, ascribed to subharmonics of the 1500-year cycle in oceanic thermohaline circulation. 102/84-year cycles are tentatively assigned to the Gleissberg period of solar activity. Phase relationships among various monsoon proxies near the onset of Termination IA suggest that summer-monsoon rains and fluvial runoff from South China had already intensified right after the last glacial maximum (LGM) insolation minimum, coeval with the start of Antarctic ice melt
\end{abstract}

\footnotetext{
* Corresponding author. Present address: Graduate School of Environmental Earth Science, Hokkaido University, Kita Ku, Sapporo W5 N10, Japan. Fax: +81-11-736-3290; E-mail: ljwang@ees.hokudai.ac.jp

${ }^{1}$ Earth and Ocean Sciences, University of British Columbia, Vancouver, Canada.

${ }^{2}$ Institute of Oceanology, Russian Academy of Science, Moscow, Russia.
} 
prior to the $\delta^{18} \mathrm{O}$ signals of global sea-level rise. Vice versa, the strength of winter-monsoon winds decreased in short centennial steps only 3000-4000 years later, along with the melt of glacial ice sheets in the Northern Hemisphere. (C) 1999 Elsevier Science B.V. All rights reserved.

Keywords: Late Pleistocene; variability of East Asian monsoon; paleoceanography South China Sea; global climate teleconnections; marine loess deposits; sub-millennial climate periodicities

\section{Introduction}

The Asian monsoon system is a thermodynamic atmospheric circulation induced by the seasonal change in heating the Central Asian highlands with their extreme lapse rate and the resulting Central Asian heat low during summer. The strong seasonality of wind directions, temperature, and precipitation forms the basis of a process that involves an extensive transport of moisture from low to high latitudes, between sea and land during summer. Similar to the global salinity conveyer belt in the ocean, the monsoon system in the atmosphere represents one of the basic elements of the global circulation. The monsoon controls the atmospheric heat budget in the Northern Hemisphere and hence, changes in monsoon have a great potential in controlling global climatic change.

The climate of the South China Sea (SCS) and the ambient land masses is dominated by the East Asian monsoon (Tchernia, 1980). Seasonal changes in winds play an important role for the short- and long-term hydrological, chemical, and sedimentological cycles in this region, and last but not least, the sea-surface circulation in the SCS. As the monsoon climate affects the most densely populated regions on our planet, both present and past changes in monsoon circulation will strongly influence the development of flora, fauna, that includes the variations of continental biomass, and finally, the evolution of mankind.

Many previous land-based studies had unraveled the long-term history of monsoon moisture as documented in the loess profiles of North China (Kukla et al., 1988; Liu and Ding, 1993; Banerjee, 1995; Porter and An, 1995). Dry phases with enhanced discharge of dust by the winter monsoon were mainly linked to glacial and cold stages, to short-term Heinrich events, and to the Younger Dryas, which was also observed in the marine sediment record of the Sulu Sea (Kudrass et al., 1991). In contrast, interglacials led to wet climate and soil formation in China (Kukla et al., 1988; Banerjee, 1995; Porter and An, 1995). An early Holocene maximum in monsoon moisture was documented in both the Arabian Sea at 11,6008600 calibrated yr BP (Sirocko et al., 1993, 1996) and China (Pye and Zhou, 1989; Shi et al., 1993; poorly dated in Winkler and Wang, 1993; Porter and An, 1995), and also in a methane maximum of the GRIP ice core (Blunier et al., 1995). Based on a marine sediment record from the Arabian Sea, the Indian monsoon varied in intra-Holocene cycles of about 1050, 1500, and 3000 years (Sirocko et al., 1996), i.e. periods similar to the climate cycles found in ice cores from Greenland (Stuiver et al., 1995; Grootes and Stuiver, 1997). One may, therefore, expect that analogous events of enhanced precipitation and fluvial runoff in South China may lead to an enlarged plume of low sea-surface salinity (SSS) offshore Hongkong (Fig. 1) and thus can be reconstructed from sediments in the northern SCS. The same principles will hold true for enhanced precipitation in Borneo, Indonesia, and Indo-China, documented in the southwestern SCS.

In this paper, we summarize various lines of isotopic, sedimentologic, and geochemical evidence from some ten deep-sea cores, obtained from regions with high sedimentation rates (reaching 7$85 \mathrm{~cm} / \mathrm{ka}$ ) along the northern, western, and southwestern margins of the SCS. These proxy records help us deciphering past seasonal monsoon signals in both subtropical and tropical parts of the SCS. Especially, we are tracing the variations in (1) moisture transport and hence, the intensity of monsoon precipitation during summer, (2) the dust transport and fluxes, i.e. wind strength and aridity during winter, moreover, (3) the signals of climatic change and vegetation cover on the dried-up Sunda subcontinent during glacial times.

Our paleomonsoon records extend over the last two glacial cycles and the subsequent deglacia- 


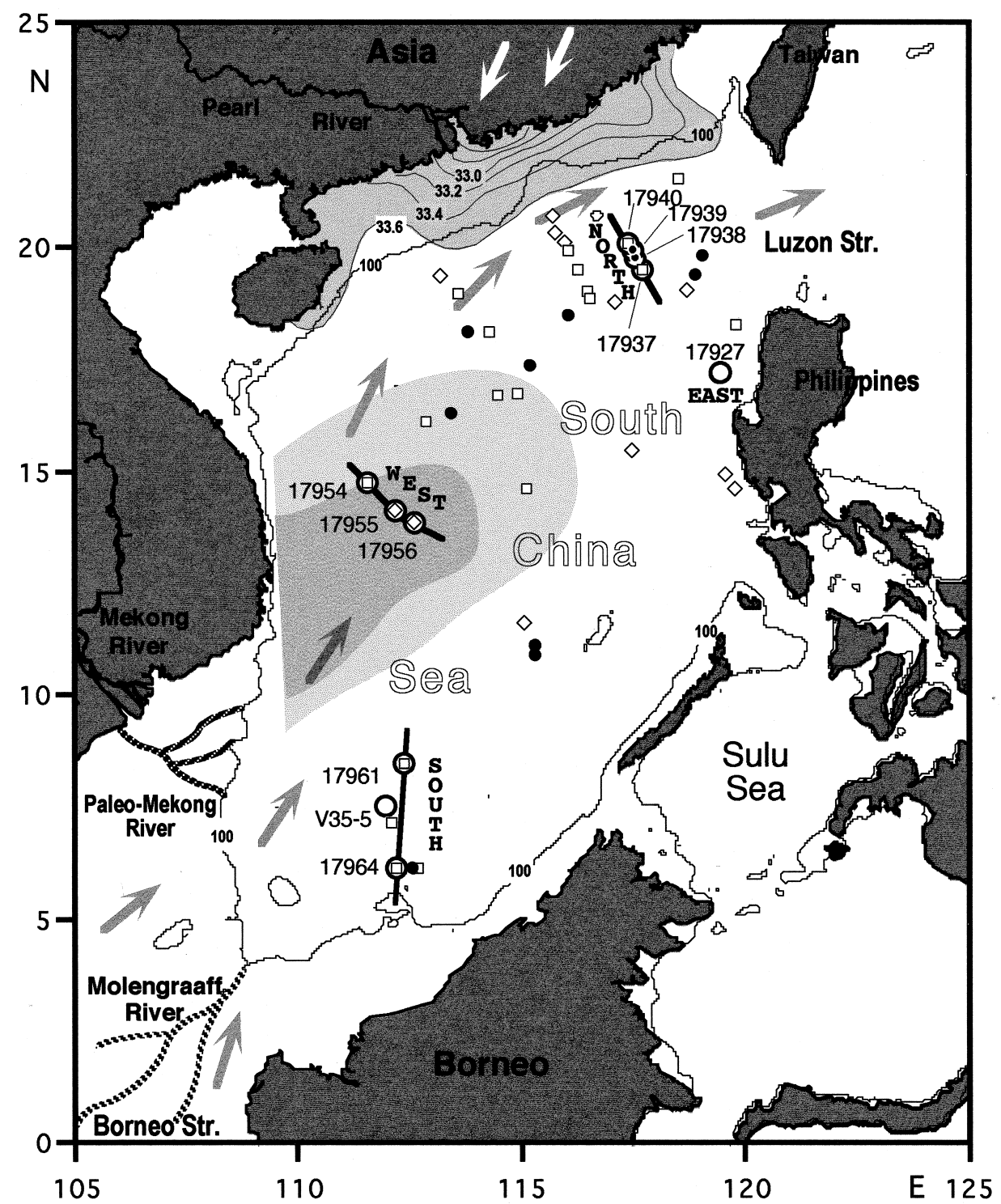

Fig. 1. Locations of 11 core sections (large open circles) on 3 transects and of 44 core-top samples from the South China Sea. Gray arrows show modern surface currents during summer; modern upwelling region southeast of Vietnam during summer is stippled (Wiesner et al., 1996); white arrows show winter monsoon. Shaded area with contour lines shows the modern freshwater plume with reduced sea-surface salinity in front of the Pearl River mouth during summer (Japan Hydrographic Association, 1978; modified). Present 100-m isobath shows approximate position of coastline during glacial low sea level. Molengraaff and Mekong rivers on the (emerged) glacial Sunda shelf are indicated in the southwestern South China Sea (Molengraaff, 1921; Tjia, 1980). Symbols of core-top samples: dots = eolian sediment supply; diamonds = sediment winnowing; squares = fluvial sediment supply (see Fig. 8A).

tions in the Pleistocene. Based on a detailed and AMS $-{ }^{14} \mathrm{C}$-dated stratigraphy for the last glacial cycle, we particularly focus on the short-term, i.e. decadal to centennial, changes in monsoonal cli- mate and trace their timing, phase relationship, and linkages in general to global climate changes such as Heinrich and/or Dansgaard-Oeschger (D-Oe) events defined in the North Atlantic realm (Bond et al., 
1992, 1997; Cortijo et al., 1995) and the associated changes in the global thermohaline circulation (Broecker et al., 1988; Sarnthein et al., 1994b; Seidov et al., 1996). Similar teleconnections were recently found and/or postulated by Kennett and Ingram (1995) and Kotilainen and Shackleton (1995) by studying paleoclimatic sediment records from the eastern and northwestern Pacific margins.

\section{Materials and methods}

\subsection{Selection of core transects and sediment samples}

All samples used in this study are selected from the core collection obtained by the 'Monitor Monsoon' Project during the FS Sonne cruise 95 in April-June 1994 (Sarnthein et al., 1994a) (Tables 1 and 2; Fig. 1). Nine gravity and/or piston cores form three major transects in the north, west, and southwest of the SCS. All cores were obtained from isolated sea-floor elevations at intermediate water depths on the continental slope and rise (Tables 1 and 2) and only contain undisturbed hemipelagic sediments with high and ultrahigh sedimentation rates. On the three core transects, the 'key' sites 17940, 17954, and 17961 have provided ultrahighresolution (bidecadal to centennial) records based on multi-proxy studies and thus form the backbone evidence of our study.

The northern transect (cores 17937-2, 17938-2, 17939-2, and 17940-1/2) extends over 400-500 km southeast of Hong Kong. This transect is located near the freshwater plume in front of the Pearl River mouth and may hence serve for monitoring past variations in fluvial discharge and monsoonal precipitation in subtropical South China. The western transect lies off South Vietnam (cores 17954-2, 17955-2 and 17956-2). The distal part of this transect extends into the area of upwelling driven by the southwest monsoon during summer (modeled by Wiesner et al., 1996; Fig. 1). Cores 17961-2 and 17964-2/3 (supplemented by VEMA core 35-5; Broecker et al., 1988, and Duplessy et al., 1991) are from the tropical southwesternmost SCS, in front of the mouth of the former 'Molengraaff' River which debouched from the Sunda shelf during times when it was dried up along with glacial low sea level (Molengraaff, 1921; Fig. 1). A further, tenth core (17927), documents the SST/SSS regime to the west of Luzon.

Table 1

Location, water depth (W.d.), and core recovery of Sonne-95 cores used in this paper

\begin{tabular}{|c|c|c|c|c|c|c|c|c|c|}
\hline \multirow[t]{2}{*}{ Site } & \multirow{2}{*}{$\begin{array}{l}\text { Latitude } \\
\text { (N) }\end{array}$} & \multirow{2}{*}{$\begin{array}{l}\text { Longitude } \\
\text { (E) }\end{array}$} & \multirow{2}{*}{$\begin{array}{l}\text { W.d } \\
\text { (m) }\end{array}$} & \multirow{2}{*}{$\begin{array}{l}\text { Recov. } \\
(\mathrm{m})\end{array}$} & \multirow[t]{2}{*}{ Corer type } & \multirow{2}{*}{$\begin{array}{l}\text { Sedirate } \\
(\mathrm{cm} / \mathrm{ka})\end{array}$} & \multicolumn{3}{|c|}{ Sample interval $(\mathrm{cm})$} \\
\hline & & & & & & & Stable isot. & Grain size & $\mathrm{U}_{37}^{\mathrm{K}}-\mathrm{PF}-\mathrm{SST}$ \\
\hline \multicolumn{10}{|c|}{ North transect } \\
\hline $17937-2$ & $117^{\circ} 39.9^{\prime}$ & $19^{\circ} 30.0^{\prime}$ & 3428 & 12.92 & SL & $11(35)$ & 10 & & \\
\hline $17938-2$ & $117^{\circ} 32.3^{\prime}$ & $19^{\circ} 47.2^{\prime}$ & 2840 & 11.78 & SL & $15(35)$ & 10 & & \\
\hline $17939-2$ & $117^{\circ} 27.3^{\prime}$ & $19^{\circ} 58.2^{\prime}$ & 2474 & 12.74 & SL & $28(34)$ & 10 & 10 & \\
\hline 17940-1 & $117^{\circ} 23.0^{\prime}$ & $20^{\circ} 07.0^{\prime}$ & 1728 & 0.56 & GKG & $50-70$ & 5 & & \\
\hline $17940-2$ & $117^{\circ} 23.0^{\prime}$ & $20^{\circ} 07.0^{\prime}$ & 1727 & 13.30 & SL & $45-85$ (19) & $1-2$ & 2 & $4-10$ \\
\hline \multicolumn{10}{|c|}{ West transect } \\
\hline 17954.2 & $111^{\circ} 31.5^{\prime}$ & $14^{\circ} 47.8^{\prime}$ & 1520 & 11.52 & SL & $6-7(5-9)$ & $2.5-10$ & & $4-10$ \\
\hline $17955-2$ & $112^{\circ} 10.6^{\prime}$ & $14^{\circ} 07.3^{\prime}$ & 2393 & 11.66 & SL & $4-5(3-6)$ & $2.5-10$ & & \\
\hline $17956-2$ & $112^{\circ} 35.3^{\prime}$ & $13^{\circ} 50.9^{\prime}$ & 3388 & 13.56 & SL & $4-5(3-5)$ & 10 & & \\
\hline \multicolumn{10}{|c|}{ South transect } \\
\hline $17961-2$ & $112^{\circ} 19.9^{\prime}$ & $08^{\circ} 30.4^{\prime}$ & 1968 & 10.30 & SL & 3-8 (10) & 10 & 10 & 10 \\
\hline $17964-2$ & $112^{\circ} 12.8^{\prime}$ & $06^{\circ} 09.5^{\prime}$ & 1556 & 13.04 & KL & $\sim 30(>55)$ & 20 & 20 & \\
\hline 17964.3 & $112^{\circ} 12.8^{\prime}$ & $06^{\circ} 09.5^{\prime}$ & 1556 & 9.12 & SL & $\sim 30(>55)$ & $8-20$ & 20 & \\
\hline \multicolumn{10}{|l|}{ East } \\
\hline $17927-2$ & $119^{\circ} 27.2^{\prime}$ & $17^{\circ} 15.1^{\prime}$ & 2804 & 5.58 & SL & $8(2-13)$ & 10 & & 10 \\
\hline
\end{tabular}

$\mathrm{SL}=$ gravity core; $\mathrm{CKG}=$ giant spade-box core; $\mathrm{KL}=$ piston core. Sedimentation rates (Sedirate) are presented separately for interglacial/Holocene and last glacial times (in brackets). 
Table 2

Location, water depth, clay content and silt-mode values of the surface sediment samples from Sonne-95 giant spade-box cores

\begin{tabular}{|c|c|c|c|c|c|}
\hline Site & $\begin{array}{l}\text { Latitude } \\
\text { (N) }\end{array}$ & $\begin{array}{l}\text { Longitude } \\
\text { (E) }\end{array}$ & $\begin{array}{l}\text { Water } \\
\text { depth } \\
\text { (m) }\end{array}$ & $\begin{array}{l}\text { Clay content, } \\
<6.3 \mu \mathrm{m} \\
(\%)\end{array}$ & $\begin{array}{l}\text { Silt- } \\
\text { mode } \\
(\mu \mathrm{m})\end{array}$ \\
\hline $17920-1$ & $119^{\circ} 45.1^{\prime}$ & $14^{\circ} 35.1^{\prime}$ & 2507 & 35.0 & 8 \\
\hline 17921-1 & $119^{\circ} 32.3^{\prime}$ & $14^{\circ} 54.7^{\prime}$ & 2507 & 41.7 & 7 \\
\hline $17922-1$ & $117^{\circ} 27.5^{\prime}$ & $15^{\circ} 25.0^{\prime}$ & 4221 & 26.3 & 10 \\
\hline 17924-1 & $118^{\circ} 50.8^{\prime}$ & $19^{\circ} 24.7^{\prime}$ & 3438 & 73.5 & 20 \\
\hline $17925-2$ & $119^{\circ} 02.8^{\prime}$ & $19^{\circ} 51.1^{\prime}$ & 2980 & 70.9 & 19 \\
\hline 17926-2 & $118^{\circ} 44.0^{\prime}$ & $19^{\circ} 00.0^{\prime}$ & 3761 & 45.0 & 13 \\
\hline $17928-2$ & $119^{\circ} 44.7^{\prime}$ & $18^{\circ} 16.3^{\prime}$ & 2486 & 55.5 & 53 \\
\hline $17929-1$ & $115^{\circ} 42.0^{\prime}$ & $20^{\circ} 40.9^{\prime}$ & 371 & 25.2 & 37 \\
\hline $17930-1$ & $115^{\circ} 46.9^{\prime}$ & $20^{\circ} 20.0^{\prime}$ & 629 & 19.7 & 28 \\
\hline 17931-1 & $115^{\circ} 57.8^{\prime}$ & $20^{\circ} 06.0^{\prime}$ & 1005 & 43.6 & 18 \\
\hline $17932-1$ & $116^{\circ} 02.3^{\prime}$ & $19^{\circ} 57.0^{\prime}$ & 1365 & 61.4 & 36 \\
\hline $17933-2$ & $116^{\circ} 13.6^{\prime}$ & $19^{\circ} 32.0^{\prime}$ & 1972 & 67.5 & 35 \\
\hline 17934-1 & $116^{\circ} 27.7^{\prime}$ & $19^{\circ} 01.9^{\prime}$ & 2665 & 71.6 & 34 \\
\hline $17935-2$ & $116^{\circ} 31.6^{\prime}$ & $18^{\circ} 52.7^{\prime}$ & 3143 & 78.4 & 57 \\
\hline 17936-1 & $117^{\circ} 07.2^{\prime}$ & $18^{\circ} 46.0^{\prime}$ & 3809 & 69.6 & 11 \\
\hline $17937-1$ & $117^{\circ} 40.0^{\prime}$ & $19^{\circ} 30.1^{\prime}$ & 3428 & 73.1 & 35 \\
\hline $17938-1$ & $117^{\circ} 32.3^{\prime}$ & $19^{\circ} 47.2^{\prime}$ & 2835 & 64.3 & 17 \\
\hline $17939-1$ & $117^{\circ} 27.3^{\prime}$ & $19^{\circ} 58.2^{\prime}$ & 2473 & 63.3 & 22 \\
\hline 17940-1 & $117^{\circ} 23.0^{\prime}$ & $20^{\circ} 07.0^{\prime}$ & 1728 & 54.3 & 50 \\
\hline 17941-1 & $118^{\circ} 28.9^{\prime}$ & $21^{\circ} 30.9^{\prime}$ & 2201 & 65.9 & 50 \\
\hline $17942-1$ & $113^{\circ} 12.1^{\prime}$ & $19^{\circ} 20.0^{\prime}$ & 329 & 20.3 & 30 \\
\hline 17943-1 & $113^{\circ} 33.2^{\prime}$ & $18^{\circ} 57.0^{\prime}$ & 917 & 59.1 & 38 \\
\hline $17945-1$ & $113^{\circ} 46.6^{\prime}$ & $18^{\circ} 07.6^{\prime}$ & 2404 & 73.0 & 16 \\
\hline $17946-1$ & $114^{\circ} 15.0^{\prime}$ & $18^{\circ} 07.5^{\prime}$ & 3465 & 68.5 & 35 \\
\hline $17947-2$ & $116^{\circ} 01.7^{\prime}$ & $18^{\circ} 28.0^{\prime}$ & 3765 & 58.4 & 30 \\
\hline 17948-1 & $114^{\circ} 53.8^{\prime}$ & $18^{\circ} 42.5^{\prime}$ & 2841 & 82.2 & 31 \\
\hline 17949.1 & $115^{\circ} 10.0^{\prime}$ & $17^{\circ} 20.9^{\prime}$ & 2195 & 68.0 & 26 \\
\hline $17950-1$ & $112^{\circ} 53.9^{\prime}$ & $16^{\circ} 05.6^{\prime}$ & 1868 & 66.7 & 34 \\
\hline 17951-1 & $113^{\circ} 24.6^{\prime}$ & $16^{\circ} 17.3^{\prime}$ & 2340 & 77.5 & 17 \\
\hline $17952-2$ & $114^{\circ} 28.4^{\prime}$ & $16^{\circ} 40.0^{\prime}$ & 2882 & 81.0 & 45 \\
\hline $17953-3$ & $115^{\circ} 08.6^{\prime}$ & $14^{\circ} 33.0^{\prime}$ & 4307 & 73.6 & 26 \\
\hline 17954-1 & $111^{\circ} 31.6^{\prime}$ & $14^{\circ} 45.5^{\prime}$ & 1517 & 60.4 & 52 \\
\hline $17955-1$ & $112^{\circ} 10.6^{\prime}$ & $14^{\circ} 07.3^{\prime}$ & 2404 & 44.0 & 18 \\
\hline $17956-1$ & $112^{\circ} 35.3^{\prime}$ & $13^{\circ} 50.9^{\prime}$ & 3387 & 52.8 & 18 \\
\hline $17957-1$ & $115^{\circ} 18.3^{\prime}$ & $10^{\circ} 53.9^{\prime}$ & 2197 & 89.8 & 14 \\
\hline $17958-1$ & $115^{\circ} 04.9^{\prime}$ & $11^{\circ} 37.3^{\prime}$ & 2581 & 62.4 & 13 \\
\hline 17959-1 & $115^{\circ} 17.2^{\prime}$ & $11^{\circ} 08.3^{\prime}$ & 1957 & 73.9 & 13 \\
\hline 17961-1 & $112^{\circ} 19.9^{\prime}$ & $08^{\circ} 30.4^{\prime}$ & 1795 & 85.6 & 28 \\
\hline $17962-1$ & $112^{\circ} 04.9^{\prime}$ & $07^{\circ} 10.9^{\prime}$ & 1970 & 79.9 & 45 \\
\hline $17963-2$ & $112^{\circ} 40.0^{\prime}$ & $06^{\circ} 10.0^{\prime}$ & 1233 & 68.2 & 55 \\
\hline $17964-1$ & $112^{\circ} 12.8^{\prime}$ & $06^{\circ} 09.5^{\prime}$ & 1556 & 67.3 & 58 \\
\hline $17965-1$ & $112^{\circ} 33.1^{\prime}$ & $06^{\circ} 09.4^{\prime}$ & 889 & 63.2 & 25 \\
\hline
\end{tabular}

\subsection{Methods and paleoclimatic proxy data}

Major unknowns of monsoonal paleoclimate are (1) continental aridity and moisture, wind strength,

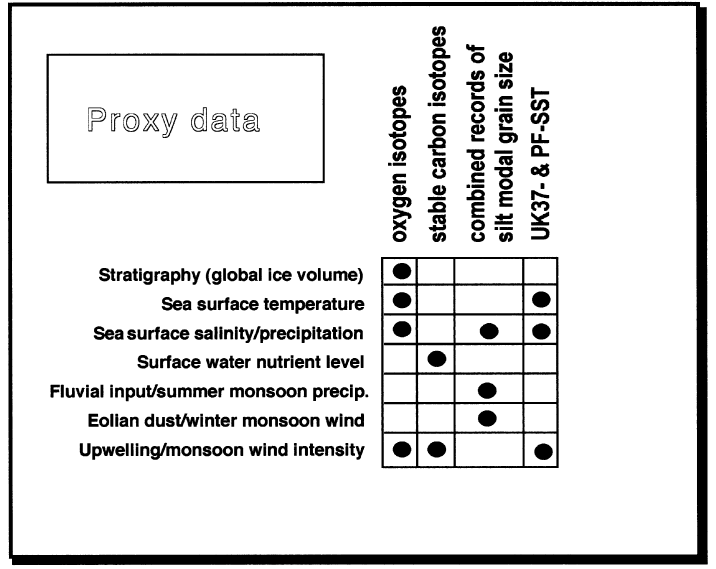

Fig. 2. Schematic summary of isotopic, micropaleontological, sedimentological, and geochemical sediment records used for calculating paleoceanographic and paleoclimatic proxy data.

and (2) temperature, salinity, nutrients, and productivity near the sea surface. These proxies are reconstructed from a broad inventory of isotopic, sedimentological, and geochemical data, summarized in Fig. 2.

Stable oxygen and carbon isotopes were measured on samples composed of 15-20 specimens of Globigerinoides ruber s.s. (white) in the 315-400 $\mu \mathrm{m}$ size fraction, which provides a record of the isotopic composition of the top $30 \mathrm{~m}$ in the surface water (Fairbanks et al., 1980, 1982; Grothmann, 1996; Mulitza et al., 1997; Wang et al., in prep.). All tests were crushed, repeatedly washed in ethanol $(99.8 \%)$ and an ultrasonic bath, and dried at $40^{\circ} \mathrm{C}$. Samples for accelerator mass spectrometry (AMS) ${ }^{14} \mathrm{C}$ dating were obtained from either $G$. ruber or $G$. sacculifer specimens, each sample amounting to $7-$ $12 \mathrm{mg}$. The samples were cleaned (without crushing the tests) in an ultrasonic bath with $99.8 \%$ ethanol and/or with distilled water. Based on eight parallel tests, these two different treatments did not result in systematic age deviations (Table 3). Stable isotopes and AMS $-{ }^{14} \mathrm{C}$ ages were measured at the Leibniz Laboratory of the Kiel University following standard procedures (Ganssen and Sarnthein, 1983; Nadeau et al., 1997; Schleicher et al., 1998). The external errors of stable-isotope analyses are $\pm 0.08 \%$ PDB and $\pm 0.06 \%$ PDB for $\delta^{18} \mathrm{O}$ and $\delta^{13} \mathrm{C}$, respectively. The average background of AMS- ${ }^{14} \mathrm{C}$ dating is $0.3 \%{ }^{14} \mathrm{C}$ (equal to about 46,000 $\mathrm{yr} \mathrm{BP}$ ). Standard errors in- 
Table 3

AMS- ${ }^{14} \mathrm{C}$ ages measured in cores $17940-2,17939-2,17961,19764^{\mathrm{a}}$

\begin{tabular}{|c|c|c|c|c|c|c|}
\hline $\begin{array}{l}\text { Sample depth } \\
\text { (cm c.d.) }\end{array}$ & $\begin{array}{l}\text { AMS }^{14} \mathrm{C} \text { age }^{\mathrm{b}} \\
(\mathrm{yr} \mathrm{BP})\end{array}$ & $\begin{array}{l}\text { Error } 1 \sigma \\
\pm(\mathrm{yr})\end{array}$ & $\begin{array}{l}\text { Planktonic foraminifera } \\
\text { species }\end{array}$ & Sample treatment & $\begin{array}{l}\text { Calibrated age } \\
(\mathrm{yr} \mathrm{BP})\end{array}$ & Notes \\
\hline \multicolumn{7}{|l|}{ Core 17940-2 } \\
\hline 22.5 & 700 & $+65 /-60$ & G. sacculifer & alc. & $670-570$ & 1,2 \\
\hline 47.5 & 1,010 & $+25 /-25$ & G. sacculifer & alc. & 930 & 1 \\
\hline 100.5 & 2,350 & $+75 /-70$ & G. sacculifer & alc. & 2,350 & 1 \\
\hline 101.5 & 2,010 & $+40 /-40$ & G. sacculifer & dist. & 1,940 & 1 \\
\hline$(101.0)$ & & & & & $2,145 \pm 55$ & 8 \\
\hline 112.5 & 2,470 & $+80 /-75$ & G. sacculifer & alc. & $2,730-2,360$ & 1,2 \\
\hline 114.5 & 2,190 & $+30 /-30$ & G. sacculifer & dist. & $2,300-2,130$ & 1,2 \\
\hline (113.5) & & & & & $2,380 \pm 205$ & 8 \\
\hline 158.5 & 2,820 & $+30 /-30$ & G. sacculifer & alc. & $2,950-2,862$ & 1,2 \\
\hline 174.5 & 3,160 & $+30 /-30$ & G. sacculifer & alc. & 3,370 & 1 \\
\hline $232.5 \mathrm{a}$ & 4,050 & $+55 /-30$ & G. sacculifer & alc. & $4,570-4,420$ & 1,2 \\
\hline $232.5 b^{c}$ & 3,970 & $+30 /-30$ & G. sacculifer & alc. & 4,420 & 1 \\
\hline$(232.5)$ & & & & & $4,460 \pm 74$ & 8 \\
\hline 252.5 & 4,660 & $+65 /-60$ & G. ruber & dist. & $5,460-5,310$ & 1,2 \\
\hline $260.5 \mathrm{a}$ & 4,310 & $+40 /-40$ & G. sacculifer & dist. & 4,860 & 1 \\
\hline $260.5 b$ & 4,390 & $+30 /-30$ & G. sacculifer & dist. & 5,030 & 1 \\
\hline 262.5 & 4,670 & $+60 /-60$ & G. sacculifer & alc. & $5,560-5,310$ & 1,2 \\
\hline (258.5) & & & & & $5,220 \pm 150$ & 8 \\
\hline 332.5 & 5,830 & $+75 /-70$ & G. sacculifer & alc. & 6,660 & 1 \\
\hline $334.5 \mathrm{a}$ & 5,710 & $+50 /-30$ & G. sacculifer & dist. & 6,490 & 1 \\
\hline $334.5 b$ & 5,700 & $+40 /-40$ & G. sacculifer & dist. & 6,480 & 1 \\
\hline$(233.5)$ & & & & & $6,560 \pm 120$ & 8 \\
\hline 372.5 & 5,930 & $+65 /-60$ & G. ruber & dist. & 6,750 & 1 \\
\hline 430.5 & 7,510 & $+60 /-60$ & G. sacculifer & dist. & 8,320 & 3 \\
\hline 432.5 & 7,810 & $+60 /-60$ & G. sacculifer & alc. & 8,550 & 3 \\
\hline 436.5 & 7,620 & $+50 /-50$ & G. sacculifer & dist. & 8,370 & 3 \\
\hline (433.5) & & & & & $8,380 \pm 130$ & 8 \\
\hline 502.5 & 8,650 & $+80 /-80$ & G. sacculifer & alc. & 9,540 & 3 \\
\hline 506.5 & 8,590 & $+90 /-90$ & G. sacculifer & dist. & $9,640-9,450$ & 2,3 \\
\hline$(504.5)$ & & & & & $9,600 \pm 190$ & 8 \\
\hline 620.5 & 9,540 & $+65 /-60$ & G. sacculifer & dist. & $10,890-10,430$ & 4,5 \\
\hline 622.5 & 9,810 & $+110 /-110$ & G. sacculifer & alc. & $11,010-10,950$ & 4,5 \\
\hline$(621.5)$ & & & & & $10,730 \pm 310$ & 8 \\
\hline 650.5 & 10,030 & $+60 /-60$ & G. sacculifer & dist. & $11,730-11,040$ & 4,5 \\
\hline 652.5 & 9,870 & $+110 /-110$ & G. ruber & alc. & $11,200-10,970$ & 4,5 \\
\hline$(651.5)$ & & & & & $11,240 \pm 360$ & 8 \\
\hline$(656.5)$ & & & & & 11,600 & 6 \\
\hline 722.5 & 11,280 & $+110 /-110$ & G. ruber & alc. & 13,280 & 7 \\
\hline 792.5 & 13,090 & $+140 /-140$ & G. ruber & alc. & 15,090 & 7 \\
\hline 842.5 & 13,960 & $+154 /-152$ & G. ruber & alc. & 17,460 & 7 \\
\hline 852.5 & 14,160 & $+161 /-157$ & G. ruber & alc. & 17,660 & 7 \\
\hline 892.5 & 15,510 & $+190 /-186$ & G. ruber & alc. & 19,010 & 7 \\
\hline 912.5 & 16,490 & $+220 /-210$ & G. ruber & alc. & 19,990 & 7 \\
\hline 922.5 & 17,260 & $+220 /-220$ & G. ruber & alc. & 20,760 & 7 \\
\hline 932.5 & 18,050 & $+140 /-140$ & G. sacculifer & dist. & 21,550 & 7 \\
\hline 1032.5 & 24,510 & $+590 /-550$ & G. ruber & alc. & 28,010 & 7 \\
\hline $1102.5 \mathrm{a}$ & 26,150 & $+330 /-320$ & G. sacculifer & dist. & 29,650 & 7 \\
\hline $1102.5 b$ & 26,840 & $+660 /-610$ & G. ruber & dist. & 30,340 & 7 \\
\hline (1102.5) & & & & & $30,000 \pm 710$ & 8 \\
\hline 1212.5 & 30,800 & $+1100 /-1000$ & G. ruber & dist. & 34,300 & 7 \\
\hline 1272.5 & 35,500 & $+2400 /-1900$ & G. ruber & alc. & 39,000 & 7 \\
\hline
\end{tabular}


Table 3 (continued)

\begin{tabular}{|c|c|c|c|c|c|c|}
\hline $\begin{array}{l}\text { Sample depth } \\
\text { (cm c.d.) }\end{array}$ & $\begin{array}{l}\text { AMS }{ }^{14} \mathrm{Cage}^{\mathrm{b}} \\
(\mathrm{yr} \mathrm{BP})\end{array}$ & $\begin{array}{l}\text { Error } 1 \sigma \\
\pm(\mathrm{yr})\end{array}$ & Planktonic foraminifera species & Sample treatment & $\begin{array}{l}\text { Calibrated age } \\
\text { (yr BP) }\end{array}$ & Notes \\
\hline \multicolumn{7}{|l|}{ Core 17939} \\
\hline 20 & 1,120 & $+30 /-30$ & G. sacculifer & alc. & $1,060-974$ & 1,2 \\
\hline $98 \mathrm{a}$ & 4,490 & $+50 /-30$ & G. sacculifer & alc. & $5,280-5,000$ & 1,2 \\
\hline $98 b$ & 4,550 & $+40 /-40$ & G. sacculifer & dist. & $5,300-5,060$ & 1,2 \\
\hline $98 \mathrm{c}^{\mathrm{c}}$ & 4,440 & $+40 /-40$ & G. sacculifer & alc. & $5,210-4,880$ & 1,2 \\
\hline 250 & 9,580 & $+60 /-60$ & G. sacculifer & alc. & $10,910-10,480$ & 4 \\
\hline $440 \mathrm{a}$ & 13,530 & $+90 /-90$ & G. sacculifer & alc. & 17,030 & 7 \\
\hline $440 b$ & 13,370 & $+90 /-90$ & G. sacculifer & dist. & 16,870 & 7 \\
\hline 490 & 13,210 & $+120 /-120$ & G. sacculifer & alc. & 16,710 & 7 \\
\hline 570 & 14,640 & $+90 /-90$ & G. sacc. + ruber & alc. & 18,140 & 7 \\
\hline 630 & 15,200 & $+110 /-110$ & G. sacc. + ruber & alc. & 18,700 & 7 \\
\hline 680 & 15,910 & $+110 /-110$ & G. sacculifer & alc. & 19,410 & 7 \\
\hline 880 & 18,950 & $+120 /-120$ & G. sacculifer & alc. & 22,450 & 7 \\
\hline \multicolumn{7}{|l|}{ Core 17961} \\
\hline 290 & 24,540 & $+290 /-280$ & G. sacculifer & dist. & 28,040 & 7 \\
\hline 310 & 25,480 & $+340 /-330$ & G. sacculifer & dist. & 28,980 & 7 \\
\hline 440 & 34,200 & $+940 /-840$ & G. sacculifer & dist. & 37,700 & 7 \\
\hline 490 & 39,700 & $+2100 /-1700$ & G. sacculifer & dist. & 43,200 & 7 \\
\hline \multicolumn{7}{|l|}{ Core 17964} \\
\hline 8 & 950 & $+35 /-35$ & G. ruber & dist. & 910 & \\
\hline 108 & 4,230 & $+60 /-59$ & G. ruber & dist. & 4,830 & \\
\hline 168 & 6,120 & $+66 /-65$ & G. ruber & dist. & 7,020 & \\
\hline 208 & 7,350 & $+74 /-73$ & G. ruber & dist. & 8,120 & \\
\hline 308 & 9,690 & $+93 /-92$ & G. ruber & dist. & 10,960 & \\
\hline 368 & 11,100 & $+120 /-120$ & G. ruber & dist. & 13,100 & 7 \\
\hline
\end{tabular}

Notes. 1: converted calendar age (Stuiver and Becker, 1993; Stuiver and Pearson, 1993); 2: age range at minor ${ }^{14} \mathrm{C}$ plateau; 3: converted calendar age (Pearson et al., 1993); 4: converted calendar age (Kromer and Becker, 1993); 5: age range at major ${ }^{14} \mathrm{C}$ plateau (Bard et al., 1990a,b); 6: calendar age of the top of the Younger Dryas (Alley et al., 1993); 7: converted calendar age (Bard et al., 1990a,b; Winn et al., 1991); 8: averaged calendar ages used in smooth-spline fit (see text for discussion).

a Average ages in core 17940 are used in Fig. 4 and Fig. 5; alc. = alcohol; dist. = distilled water.

${ }^{\mathrm{b}}$ A 400 -yr correction is applied for the reservoir age of sea water, although its precise age range is unknown in the South China Sea (Stuiver and Braziunas, 1993).

${ }^{\mathrm{c}}$ Foraminiferal tests with $80 \%$ of size fraction $150-315 \mu \mathrm{m}$.

cluding the background radioactivity were calculated per sample batch.

Based on both the $\delta^{18} \mathrm{O}$ and $\delta^{13} \mathrm{C}$ records of two core sections from giant spade-box core 17940-1 with $45 \mathrm{~cm}$ and neighbor gravity core 17940-2 with $1315 \mathrm{~cm}$ length, we spliced a composite-depth (c.d.) section at site 17940 , where $0 \mathrm{~cm}$ in $17940-2$ is equal to $2.5 \mathrm{~cm}$ depth in 17940-1. This core fit ensures the recovery of the genuine sediment surface for the reconstruction of our paleoclimatic records.

Siliciclastic grain sizes and clay contents were measured on a SediGraph 5100D made by Micromeritics according to procedures described by Stein (1985). Samples for SediGraph analyses were obtained from the $<63 \mu \mathrm{m}$ sediment fraction after washing the bulk sample over a $63 \mu \mathrm{m}$ sieve and completely dissolving the carbonate and organic carbon fractions in acetic acid and hydrogen peroxide solutions. The clay content was defined as the percentage of the acid insoluble grain-size fraction smaller than $6.3 \mu \mathrm{m}$, a boundary that is crucial in aerosol transport (Parkin and Shackleton, 1973). The grain-size mode was derived from both the bulk and silt fractions. Based on 157 replicate measurements the mean analytical errors of modal grain sizes and clay contents are $0.77 \pm 1.13 \mu \mathrm{m}$ and $0.22 \pm 0.46 \%$, respectively. Wind-supplied (dust) and river-borne (mud) sediments, i.e. crucial signals of aridity and 
humidity, were finally identified by means of the 'Koopmann Index' (Koopmann, 1981; Stein, 1985), an empirical relationship between the percentage of silt $>6.3 \mu \mathrm{m}$ (abscissa) and the modal grain size of silt $>6.3 \mu \mathrm{m}$ (explained in detail in the caption of Fig. 6 and, especially, Fig. 8).

Sea-surface temperature (SST) estimates are based on the biomarker $\mathrm{U}_{37}^{\mathrm{K}}$ index (annual mean SST at $0-30 \mathrm{~m}: \mathrm{U}^{\mathrm{K}}{ }_{37}=0.36 T-0.056$; Kirch, 1997; Pelejero and Grimalt, 1997; Pelejero et al., 1999). Based on five replicate extractions of alkenones from sediment samples, the error of these estimates is about $\pm 0.15^{\circ} \mathrm{C}$. We also used CLIMAP-style planktonic foraminiferal (PF) census data, which were converted into SST of the 'sea surface' using the FP-12E transfer function of Thompson (1981) (core 17940: Pflaumann and Jian, 1999; core 17954: combined counts of Ivanova, Pflaumann, Heilig). For equation $\mathrm{FP}-12 \mathrm{E}$ the error is $\pm 1.46^{\circ} \mathrm{C}$ for summer and $\pm 2.48^{\circ} \mathrm{C}$ for winter. Pflaumann and Jian (1999) are assessing the differences between PF-based SST records derived from (1) a new Modern Analog (SIMMAX 28) equation, (2) the FP-12E transfer function, and (3) from $U_{37}^{K}$ data. The $U_{37}^{K}$-based annual mean SST values for $0-30 \mathrm{~m}$ also served for calculating paleosalinity data.

Local paleosalinities of surface water (SSS) were estimated by subtracting the past variations in SST and global ice-volume from the planktonic $\delta^{18} \mathrm{O}$ signal of G. ruber (white), using the transfer equation of L. Wang et al. (1995). Thus the SSS values apply to water depths that depend (1) on the depth range of the SST estimates employed, and (2) on the habitat depth of $G$. ruber forming its $\delta^{18} \mathrm{O}$ signal within 0-50 m water depth (Tolderlund and Bé, 1971; Fairbanks et al., 1980; Williams et al., 1981; Hemleben et al., 1989). Approximately in harmony with this habitat depth, we used our $\mathrm{U}_{37}^{\mathrm{K}}$-based annual-mean SST estimates for $0-30 \mathrm{~m}$ for calculating the SSS values, although summer SST at $0-50 \mathrm{~m}$ originally served as basis for defining the transfer function of L. Wang et al. (1995).

We employed annual mean $\mathrm{U}_{37}^{\mathrm{K}}$ SST instead of summer $\mathrm{U}_{37}^{\mathrm{K}} \mathrm{SST}$ for various reasons. (1) Different from the northeastern subtropical Atlantic the modern SST range in the SCS provides optimum habitat conditions for a perennial formation of $G$. ruber and its $\delta^{18} \mathrm{O}$ signal (Hemleben et al., 1989). (2) Accord- ingly, sediment traps in the northern and central SCS recovered maximum fluxes of $G$. ruber in both late summer and early winter (Wiesner et al., 1996). (3) $\mathrm{U}_{37}^{\mathrm{K}}$-based annual mean SST largely equate to both annual mean PF-SST data (see below) and modern average temperatures (Levitus and Boyer, 1994). Moreover, annual mean $\mathrm{U}_{37}^{\mathrm{K}}$ SSTs were preferred to PF-SSTs to avoid (1) a potential bias in PF-SST signals linked to the impact of local changes in subsurface oceanography on certain foraminifera species (e.g. possibly causing some late Holocene SST minima), and (2) the artificial high-amplitude noise in PF-SST estimates of single samples. This noise may result from both errors in PF census data and the standard error of the transfer function (Thompson, 1981) and hence may strongly bias the SSS values in ultrahigh-resolution records, especially during phases of rapid climate change. To establish the same sampling resolution for both the high-resolution (1$2 \mathrm{~cm}) \delta^{18} \mathrm{O}$ curve and the medium high-resolution $(5 \mathrm{~cm})$ SST records of core 17940, the $\mathrm{U}_{37}^{\mathrm{K}} \mathrm{SST}$ data were interpolated by a smooth-spline to avoid artificial variability.

The global $\delta^{18} \mathrm{O}$ ice effect was calculated using our planktonic $\delta^{18} \mathrm{O}$ stratigraphy (Fig. 3a) and the pertinent $\delta^{18} \mathrm{O}$ records of Labeyrie et al. (1987), Fairbanks (1989), and Vogelsang (1990). In core 17961, we used the benthic $\delta^{18} \mathrm{O}$ stratigraphy (Fig. 3c) for calculating the $\delta^{18} \mathrm{O}$ ice effect, since the planktonic $\delta^{18} \mathrm{O}$ record appears strongly affected by local salinity changes at this site during Termination IA (Fig. 3a).

A tentative calculation of SSS using the equations of Rostek et al. (1993) produces almost identical results within the standard error of $0.68 \%$ o resulting from the equation of L. Wang et al. (1995).

The complete proxy data sets ('Monitor Monsoon') are available on request from the German 'Past Global Changes' (PAGES) marine data repository PANGAEA (http://www.pangaea.de and grobe@awi-bremerhaven.de).

\section{Results}

\subsection{High-resolution $\delta^{18} \mathrm{O} / \delta^{13} \mathrm{C}$ stratigraphy}

Based on the stage definitions by Prell et al. (1986) and Martinson et al. (1987), the $\delta^{18} \mathrm{O}$ records 


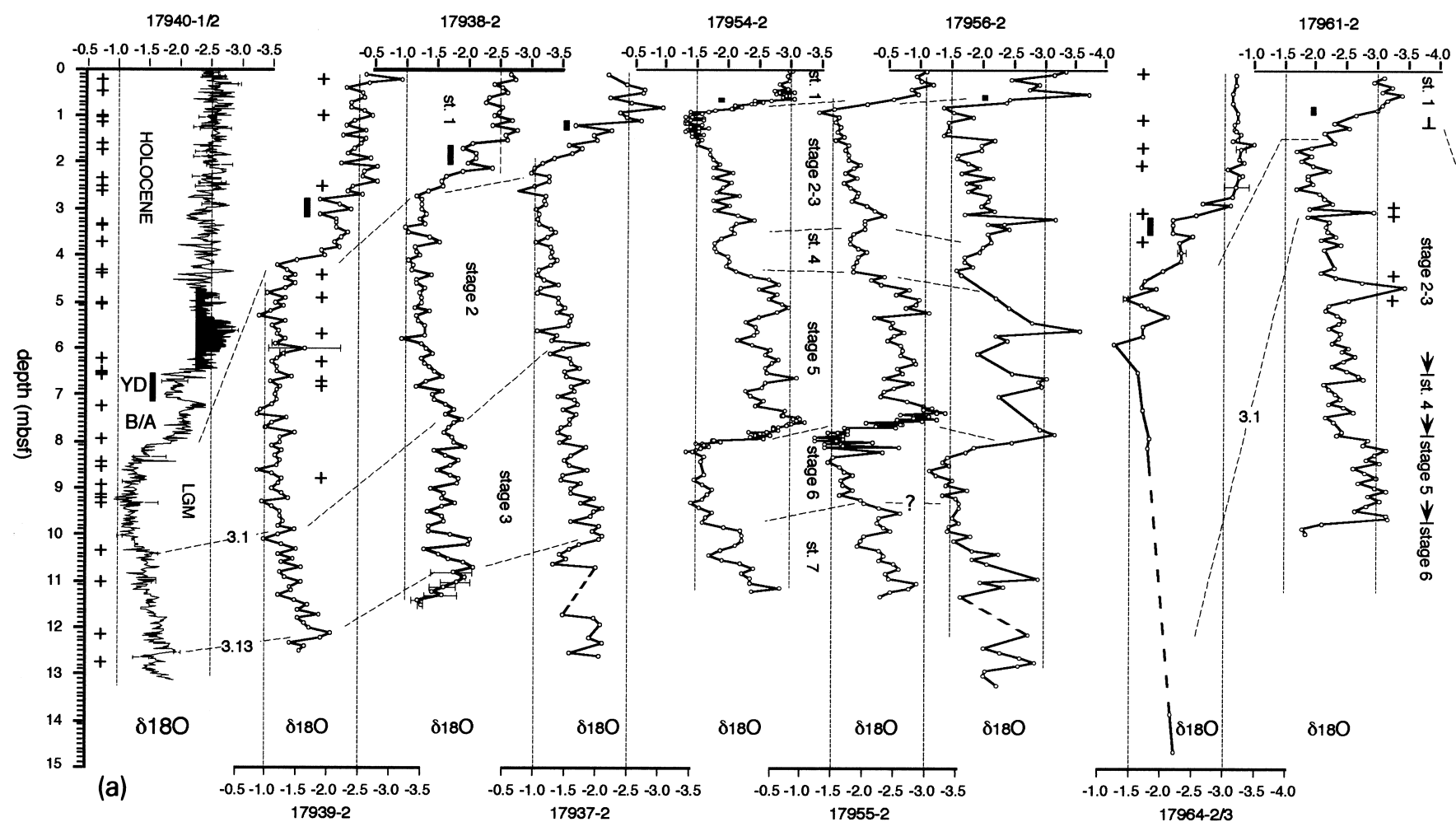

17954-2

17956-2

17961-2

17927-2

$-0.5-1.0-1.5-2.0-2.5-3.0-3.5$
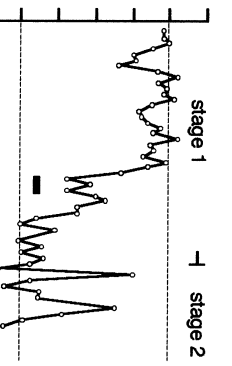

Fig. 3. (a) Oxygen and (b) carbon isotope records measured on planktonic Globigerinoides ruber s.s. (white) and on (c) epibenthic Cibicidoides wuellerstorfi and C. kullenbergi in sediment cores from the SCS (Fig. 1). Crosses show AMS- ${ }^{14} \mathrm{C}$-dated levels (Table 2). Marine isotope stages are labeled and stage boundaries are connected by dashed lines between the different records for each transect. Event 3.1 in 17964 is inferred from the benthic $\delta^{18} \mathrm{O}$ record (Fig. 3c). Vertical dotted lines for each core were added to facilitate comparison of absolute values. Thick dashed lines in isotope records indicate data gaps that result from a lack of foraminifera specimens. Error bars in 17940 records show standard error of multiple measurements. Broad vertical bars indicate Younger Dryas $(Y D)$ event. $B / A=B \varnothing l l i n g-A l l e r ø d$. $L G M=$ Last Glacial Maximum. Note the extreme benthic $\delta^{13} \mathrm{C}$ minima linked to organic fluff layers and an oxygen-minimum layer, strongly developed along the continental margins. At site 17940 off Hong Kong the benthic $\delta^{13} \mathrm{C}$ minimum $\left(-1.4 \%\right.$ ) in the earliest Holocene is coeval with maximum runoff of the Pearl River $\left(540 \mathrm{~cm}\right.$ c.d.; about $9000{ }^{14} \mathrm{C}$ years $\left.\mathrm{BP}\right)$. The benthic $\delta^{13} \mathrm{C}$ minimum $(-1.3 /-1.6 \%$ ) in core 17964 from the southern margin of the SCS accompanies the runoff of the Molengraaff River during Stage 2. Data of core 17927 are from Kirch (1997). 


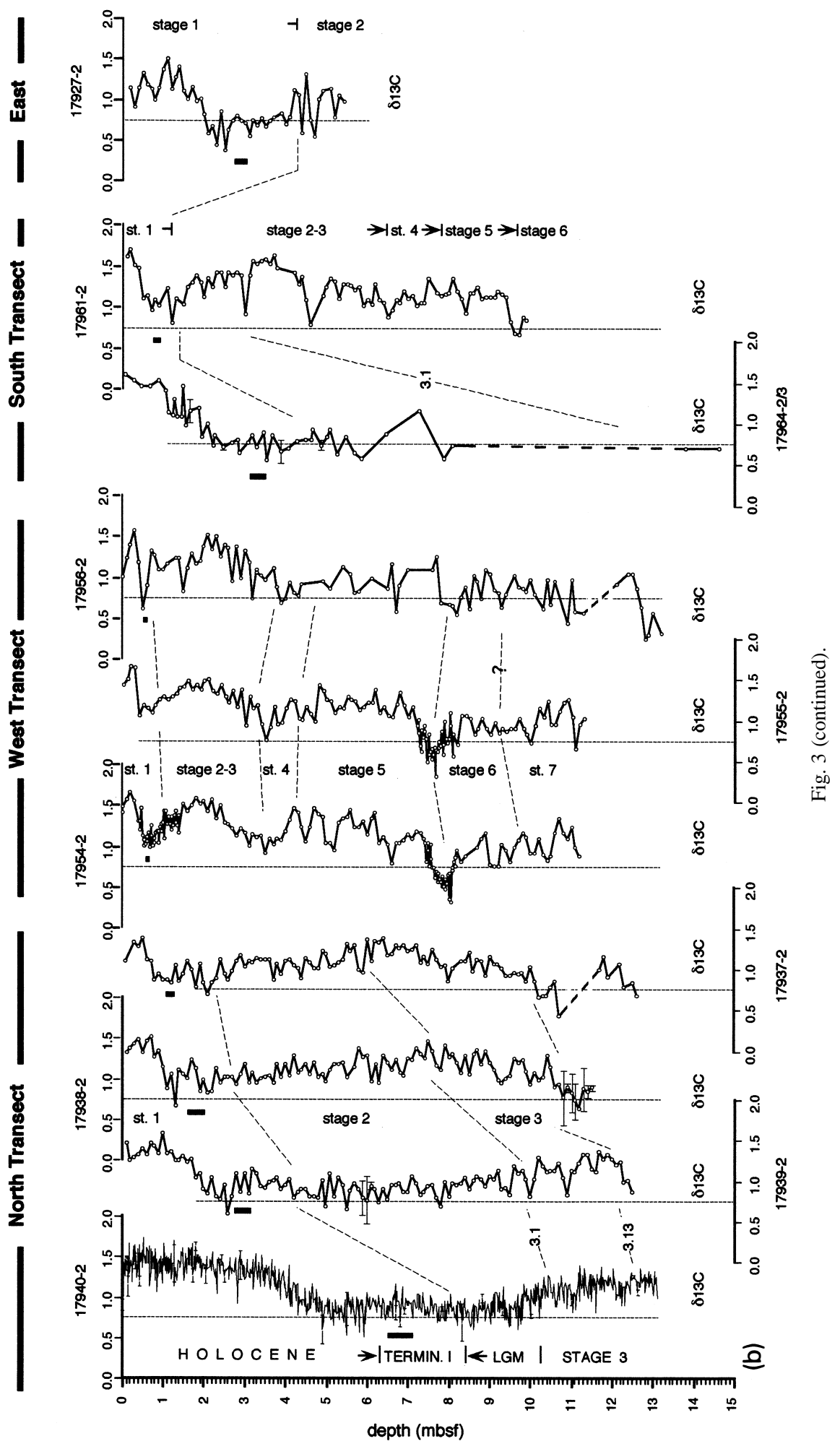



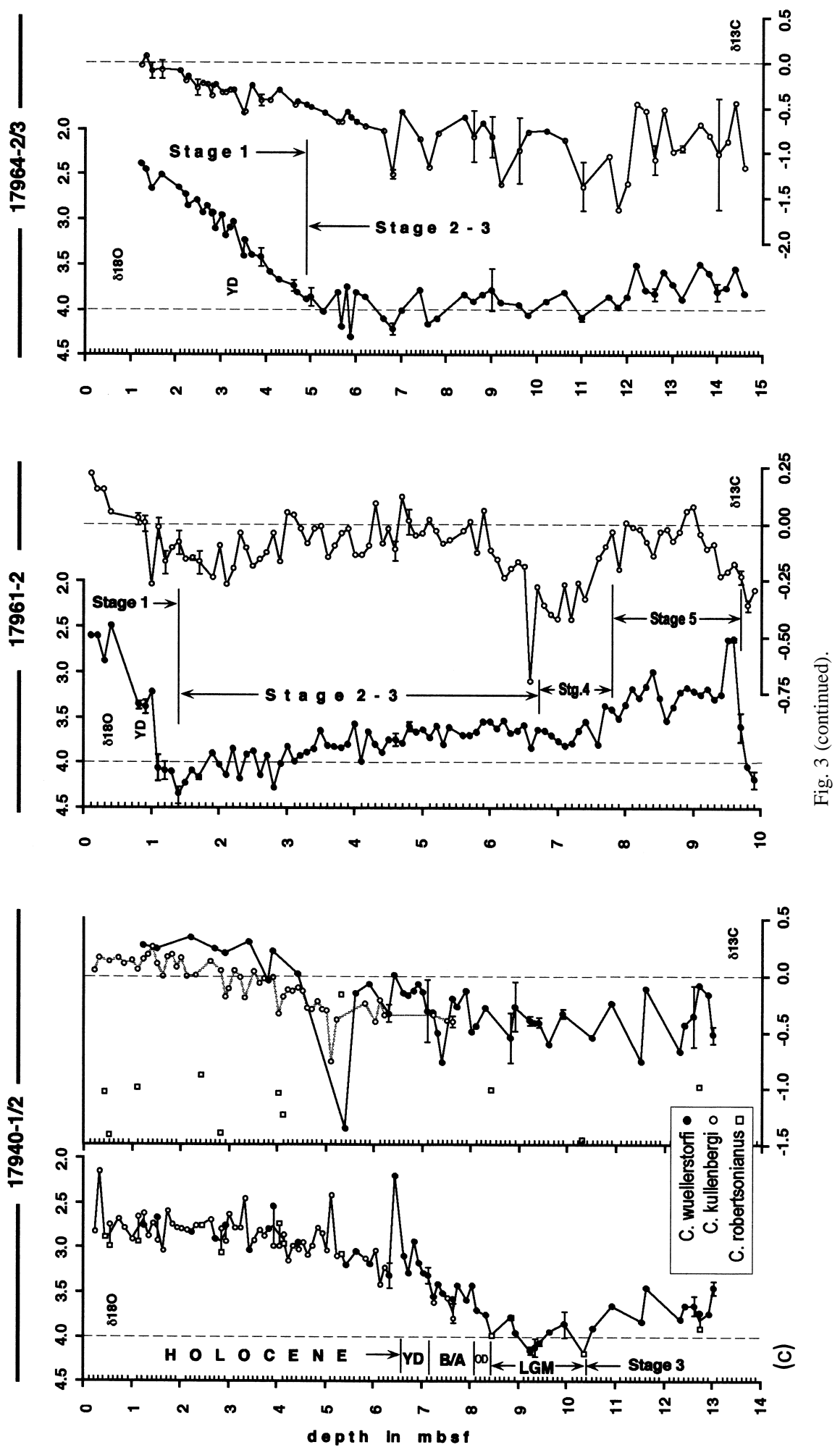
from our ten core sections (Fig. 3) comprise the global standard variations of the last (cores 17927 and 17937-40, northeastern SCS, and cores 17961 and 17964, southern SCS), or last two glacial cycles back to early Stage 7 (cores 17954-56, western SCS). In the western transect the details of the glacial terminations are not as well resolved as in the cores of the northern transect. In the west, the $\delta^{18} \mathrm{O}$ shifts of the last two glacial-to-interglacial cycles reach the same order of magnitude, with only slightly lighter $\delta^{18} \mathrm{O}$ values $(0.1-0.2 \%$ ) in the Eemian than in the Holocene. In the south, especially the benthic $\delta^{18} \mathrm{O}$ curve of core 17961 reveals a clear record of Stages $1-5$ back to substage 6.2. The benthic $\delta^{18} \mathrm{O}$ values in core 17964 reach back to the upper part of Stage 3 (Fig. 3c). The precise age range, however, cannot be determined in core 17964 because of the rareness of foraminifera tests, probably due to extreme sediment dilution.

The planktonic glacial-to-interglacial $\delta^{18} \mathrm{O}$ variations amount to about $1.7 \%$ and are superimposed by a few short-term extreme $\delta^{18} \mathrm{O}$ minima in the Holocene, reaching less than $-3.0 \%$ (cores 17939 and 17937; Fig. 3a). In core 17956, oxygen isotope variations amount to about $2.0 \%$ due to the extremely light $\delta^{18} \mathrm{O}$ values in the earliest Stage 1 and in Stage 5.1, moreover in substage 3.3. The $\delta^{18} \mathrm{O}$ values of the western and southern transects are generally lighter (by $\geq 0.5 \%$ ) than those of the northern transect. This difference is largely ascribed to different SSTs which are higher in the tropical waters of the southern and western transects than in the northern, subtropical SCS (Japan Hydrographic Association, 1978).

Besides the major glacial and interglacial $\delta^{18} \mathrm{O}$ stages, a number of small-scale, but equally important $\delta^{18} \mathrm{O}$ excursions characterize early Stage 1 and Stage 3 in most records (Fig. 3), especially in core sections with high sedimentation rates. Here a detailed Holocene and deglaciation history is documented in the northern SCS, starting with a distinct Bølling-Allerød (B/A) warm phase. The intraHolocene ultrarapid climatic changes are reflected by major $\delta^{18} \mathrm{O}$ oscillations reaching $0.7-1.0 \%$ o. In the northern transect the Younger Dryas (YD) event is clearly recorded as a major $\delta^{18} \mathrm{O}$ increase by $0.5-$ 0.7\%o. This excursion even contains the characteristic double-peak structure found in the Greenland ice-core records (Alley et al., 1993; Stuiver et al., 1995) (Figs. 3 and 4). In cores from the western and southern transects - further away from the northern freshwater sources - the YD-style signals are also recorded either as $\delta^{18} \mathrm{O}$ plateau and/or slight $\delta^{18} \mathrm{O}$ increase on top of the general deglacial trend at both Termination I (cores 17954 and 17961) and II (high-resolution records of cores 17954 and 17955).

The end of the last glacial maximum (LGM) is well defined by a major $\delta^{18} \mathrm{O}$ shift of about $0.5-0.7 \%$ o toward the Bølling-Allerød level. Prior to this shift, core 17940 shows a minor overall $\delta^{18} \mathrm{O}$ decrease by about $0.4 \%$ at about $850-810 \mathrm{~cm}$ core depth, a decrease superimposed by two spikes of light $\delta^{18} \mathrm{O}$ values beyond the analytical noise level (Fig. 3a and Fig. 4). The spikes possibly mark the actual onset of glacial Termination Ia, which subsequently was interrupted by the Oldest Dryas stadial. As compared to the fairly stable LGM $(890-1030 \mathrm{~cm}$ depth in core 17940) $\delta^{18} \mathrm{O}$ Stage 3 is characterized by ultrarapid $\delta^{18} \mathrm{O}$ oscillations. They reach $0.7 \%$ in the northern and western cores 17940, 17954 and 17955 and exceed $1.5 \%$ in the southwestern cores 17956 and (especially) 17961. These short-term $\delta^{18} \mathrm{O}$ signals are ascribed to freshwater pulses (see Section 4).

The benthic $\delta^{18} \mathrm{O}$ records (cores 17940, -61, -64; Fig. 3c) largely parallel the planktonic $\delta^{18} \mathrm{O}$ records, except for the salient Pacific-style minimum of Stage 5.5 in core 17961. Special features of the benthic $\delta^{13} \mathrm{C}$ records are discussed below.

Planktonic $\delta^{13} \mathrm{C}$ records from the SCS (Fig. 3b) show glacial-to-interglacial variations of 0.5 to $1.0 \%$ o over the past 250,000 years. In all cores, the extremes in low $\delta^{13} \mathrm{C}$ are linked to the onset and end of glacial terminations, such as after glacial Stages 2, 4, and 6 . For example, in cores 17954, -56 and -61 the $\delta^{13} \mathrm{C}$ minima across the Stage 6-Stage 5 boundary exceed the minima across the Stage 2-Stage 1 boundary by about $0.5 \%$ o, a trend observed in many planktonic and benthic records worldwide (e.g. Sarnthein and Tiedemann, 1990). Within Stage 3, major short-term planktonic $\delta^{13} \mathrm{C}$ lows parallel lows in $\delta^{18} \mathrm{O}$, most obviously in core 17961 (near 300, 450, and $650 \mathrm{~cm}$ depth). 


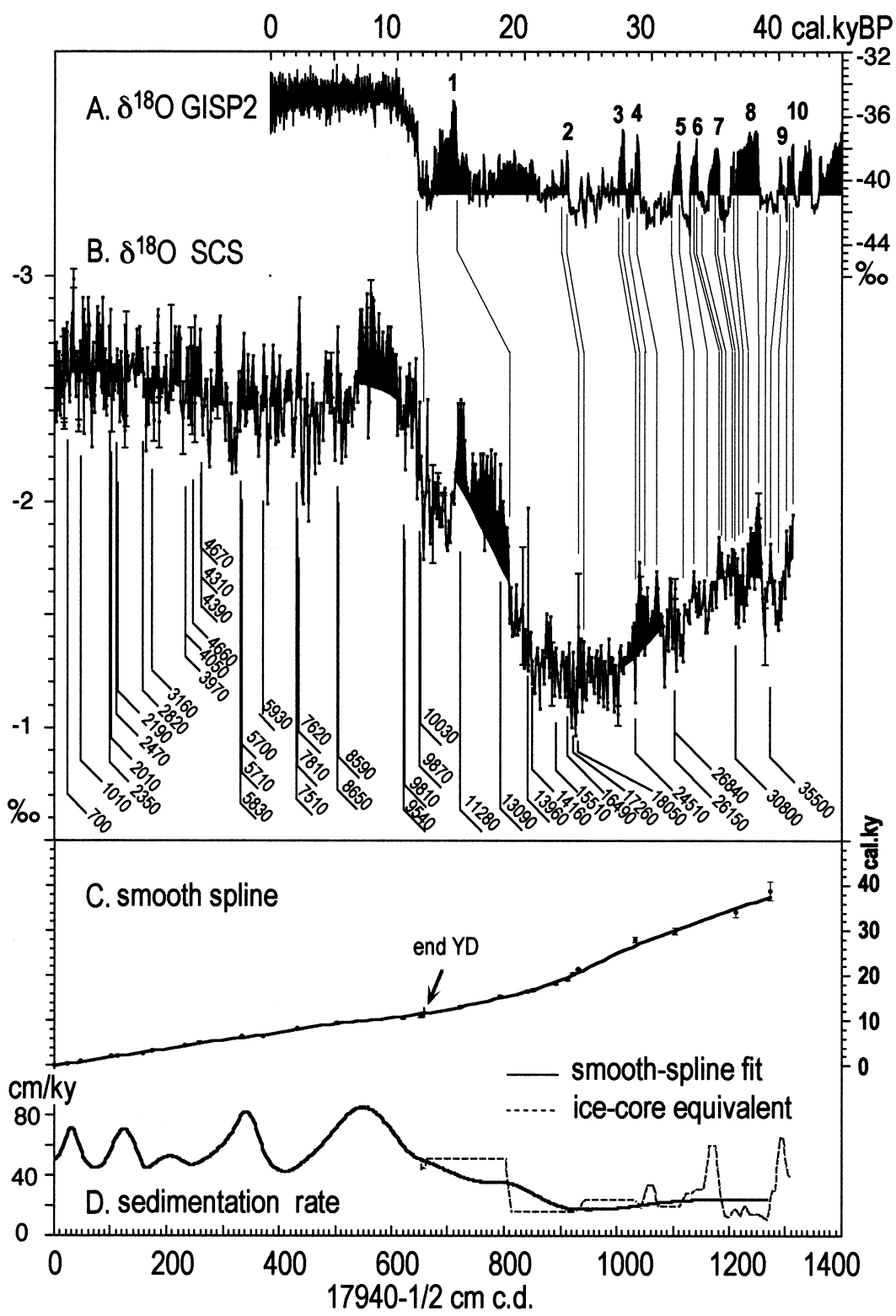

Fig. 4. (A) Age model of ice-core GISP2 (Grootes and Stuiver, 1997) and (B) of core 17940, based on AMS $-{ }^{14} \mathrm{C}$ ages $(\mathrm{Table} 2)$ labeled below the planktonic $\delta^{18} \mathrm{O}$ curve. Composite depth (c.d.) values are based on core-fit between giant spade-box core 17940-1 and gravity core 17940-2 (see text for details). The age-depth curve (C) is based on a smooth-spline fit across the age-depth control points, where ${ }^{14} \mathrm{C}$ ages are converted into calendar ages. Duplicate/multiple ${ }^{14} \mathrm{C}$ datings are averaged (after conversion into calendar years; Table 2); age errors are calculated via a Gaussian error-propagation equation. Below the Preboreal (>11,600 calendar yr BP) the chronostratigraphy in core 17940 is established via tuning the light $\delta^{18} \mathrm{O}$ peaks in Stages 2-3 to warm Dansgaard-Oeschger (D-Oe) events $2-10$ in the $\delta^{18} \mathrm{O}$ record of the annual-layer counted ice-core GISP2 (thin lines between (A) and (B)). This correlation is made per analogy to the fit of $\delta^{18} \mathrm{O}$ excursions at the YD and B/A events. Sedimentation rates in Stages 2-3 are derived from linear interpolation between age-control points deduced from tuning to D-Oe events (dashed line in (D)). For comparison, sedimentation rates are calculated from the first derivative of the smooth-spline (solid line in (D)). 


\section{2. $A M S-{ }^{14} C$ dates and age control}

AMS radiocarbon ages provided an (apparently direct) age control in cores 17940, 17939, 17961, and 17964 back to $40 \mathrm{ka}$ (Table 3). Based on these dates we set up a first age model for the last glacial cycle, especially for confining the events and periodicities of monsoon climate over the last deglaciation and the Holocene. The most detailed age model for the last glacial cycle was established in core 17940 , where 40 AMS $-{ }^{14} \mathrm{C}$ dates were measured (Fig. 4; Table 3).

For the calculation of accumulation rates we converted the ${ }^{14} \mathrm{C}$ ages into calendar ages, which implied two major unknowns: (1) changes in the ${ }^{14} \mathrm{C}$-reservoir effect of the surface water in the SCS; and (2) the differential ${ }^{14} \mathrm{C}$-production rates in the atmosphere during the last glacial cycle (Duplessy et al., 1989; Stuiver and Braziunas, 1993; Laj et al., 1996; Völker et al., 1998). The ${ }^{14} \mathrm{C}$ ages of dissolved $\mathrm{CO}_{2}$ in surface-water samples from the SCS (unpublished data) show a post-bomb age of -750 years. Fairly conventional reservoir ages of +400 and +730 years occur at 250 and $400 \mathrm{~m}$ depth, respectively. In the glacial SCS the ${ }^{14} \mathrm{C}$-reservoir effect was possibly much larger than today (Duplessy et al., 1989; Adkins and Boyle, 1997), since the glacial SCS probably had an estuarine circulation which was fed by old West Pacific intermediate- to deep-water masses that mark the end of the global thermohaline circulation in the ocean (Gordon, 1986; L. Wang, 1992; P. Wang, 1992). The estuarine system resulted from a perfect isolation of the SCS to the southwest as soon as the sea level was lowered by more than $40 \mathrm{~m}$ and the straits of Borneo were closed, different from today, when abundant young surface water is entering from the Indian Ocean.

Based on dates of Shackleton et al. (1988) the synglacial Pacific intermediate water reached an age of about 2400 years. If this age also holds true for the (upwelled) estuarine surface water of the glacial SCS, the resulting ${ }^{14} \mathrm{C}$ anomaly was just opposed to the age difference resulting from an increased cosmogenic ${ }^{14} \mathrm{C}$ production in the atmosphere during that time, that led to a reduction of ${ }^{14} \mathrm{C}$ ages by 3000 to 4000 years versus calendar ages (Bard et al., 1990a; Völker et al., 1998).

In our approach, ${ }^{14} \mathrm{C}$ dates of the last 11,000 years were converted into calendar ages, based on the cali- bration technique of Stuiver and Braziunas (1993) and taking into account a minor additional reservoir age for the western Pacific $(140 \pm 45 \mathrm{yr}$; i.e. a total of 540 yr). Beyond the calibration range of dendrochronology, ${ }^{14} \mathrm{C}$ years were corrected by $2000-3500$ years (Table 3), using calibration schemes based on rare UTh ages (Bard et al., 1990a; Winn et al., 1991) and varves (Hughen et al., 1998). In this first simple conversion no higher ${ }^{14} \mathrm{C}$-reservoir ages are considered.

In the Holocene section, any age model of core 17940 , which is based on a simple linear interpolation of the numerous, closely packed ${ }^{14} \mathrm{C}$ dates, would suffer from various severe artifacts. They would result in strongly fluctuating sedimentation rates with highly questionable extremes. To cope with this problem, we built our age model on the assumption of more uniform sedimentation rates by (1) averaging the (calibrated) calendar ages obtained from any core section less than $10 \mathrm{~cm}$ thick (Table 3), and (2) applying a smooth-spline (Reinsch, 1967) through the dated depth levels (Fig. 4).

In $\delta^{18} \mathrm{O}$ Stage 3 the conversion of ${ }^{14} \mathrm{C}$ dates into calendar ages is more complicated than in Stages 12 because of (1) poorly quantified but strong variations in cosmogenic ${ }^{14} \mathrm{C}$ production (Laj et al., 1996; Völker et al., 1998), which result in (2) various ${ }^{14} \mathrm{C}$ rises and plateaus that lack any $\mathrm{U} / \mathrm{Th}$-calibrated age-control points (Bard et al., 1990a), and finally, (3) because of unknown but probably considerable variations in the local ${ }^{14} \mathrm{C}$-reservoir effect. Therefore, we adopted a different, 'direct' approach to chronostratigraphy: we tied the $\delta^{18} \mathrm{O}$ minima of core 17940 in Stages 2 and 3 to ice-varve ages of the warm D-Oe events recorded in the $\delta^{18} \mathrm{O}$ curve of the GISP2 ice core (Grootes and Stuiver, 1997). This approach is based on the assumption that the $\delta^{18} \mathrm{O}$ minima equate to monsoonal precipitation maxima near site 17940 , which, in turn, directly parallel the highs in air temperature (and snow accumulation) on the Greenland summit (Fig. 4). Indeed, the pronounced $\delta^{18} \mathrm{O}$ minima in both the Bølling-Allerød and the Preboreal to early Holocene of core 17940 are readily explained by maxima in summer-monsoon precipitation, as the local SST do not show any comparable increase during these times (see below and Fig. 9). The $\delta^{18} \mathrm{O}$ record between the age-control points that were tied to Dansgaard-Oeschger events 1-10 was simply telescoped in core 17940 (Fig. 4). 
The switch point between the calibrated calendar ages of the Holocene and the ages derived as direct equivalents of ice-core stratigraphy occurs at the end of the YD event, 11,600 yr BP (= equivalent age according to Alley et al., 1993 and Stuiver et al., 1995), at $656.5 \mathrm{~cm}$ composite depth (c.d.). The lower end of the YD is constrained by a calendar age of $13,280 \pm 110 \mathrm{yr}$ BP obtained for the Allerød $\delta^{18} \mathrm{O}$ minimum at $722.5 \mathrm{~cm}$ c.d. in core 17940 (Table 3).

In Stages 2 and 3 the difference between the correlated ice-core equivalent ages and the foraminiferal ${ }^{14} \mathrm{C}$ ages amounts to $3000-5100$ years (Fig. 5). These anomalies differ from the 'constant' age shift of 3500 years, originally inferred from three first coral ${ }^{14} \mathrm{C}$ dates calibrated by U-Th ages (Winn et al., 1991; Bard et al., 1998). ${ }^{14} \mathrm{C}$-age shifts that exceed 3500 years, despite a potentially high ${ }^{14} \mathrm{C}$-reservoir effect, imply a substantially increased rate of radiocarbon production during that time, similar to rates found in the Nordic Seas (Völker et al., 1998).

In our cores we generally employed the GISP2equivalent ages for Stages 2 and 3, for example, for assessing the global climatic correlations of shortterm climate events. Prior to Stage 3, the astronomi-

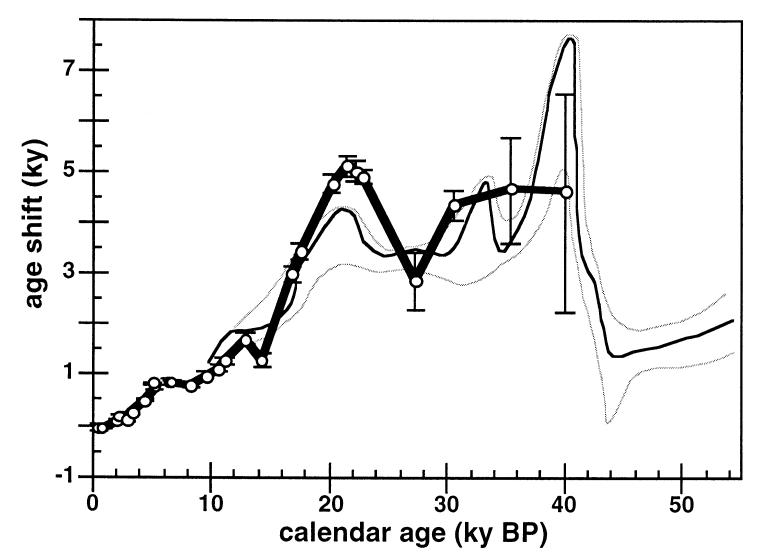

Fig. 5. Deviation of AMS- ${ }^{14} \mathrm{C}$ ages in core 17940 (corrected for a ${ }^{14} \mathrm{C}$-reservoir age of 400 years; Table 2) from GISP2 calendar ages (broad line) as deduced from tuning the two paleoclimatic records (Fig. 4A,B). Error bars show $1 \sigma$ standard error of ${ }^{14} \mathrm{C}$ dates. Thin lines depict global ${ }^{14} \mathrm{C}$-age shift (visual-fit trend line and envelope) estimated from ${ }^{14} \mathrm{C}$ values measured in two Nordic Sea cores and tuned to the GISP2 ice record (Völker et al., 1998). Differences in ${ }^{14} \mathrm{C}$ shifts between records from SCS and Nordic Seas are assigned to differential ${ }^{14} \mathrm{C}$-reservoir effect of SCS surface water. cally tuned SPECMAP- $\delta{ }^{18} \mathrm{O}$ stratigraphy (Martinson et al., 1987) was employed for cores 17954-56 and 17961. In Figs. 3-10a, however, we display the various stratigraphic records and proxy data from different cores on the simple depth scale ( $\mathrm{cm}$ below sea floor) to provide direct information of original data (Fig. 10b and Fig. 11 show the SSS records against calendar years).

\subsection{Sedimentation rates}

The four $\delta^{18} \mathrm{O}$ records of the northern core transect (17937-40; Fig. 1) document a region with the highest hemipelagic sedimentation rates ever found in the SCS (25-85 cm/ka; Fig. 4). Accordingly, a $1-\mathrm{cm}$ sampling resolution results in a time resolution of 20-30 years in the Holocene and about 40 years in Stages 2 and 3. The sedimentation rates on the continental slope vary with increasing distance from the shelf break. The shallowmost site 17940 shows a maximum thickness of $6.5 \mathrm{~m}$ for the Holocene. More distally, on the deeper continental slope, the Holocene sediment thickness decreases to about 2.7, 1.5 and $1.1 \mathrm{~m}$ in cores 17939, 17938 and 17937, respectively (Fig. 3a). The glacial sections show the opposite trend, with sedimentation rates increasing offshore from $19 \mathrm{~cm} / \mathrm{ka}$ in core 17940 to $34-35$ $\mathrm{cm} / \mathrm{ka}$ in cores $17939-17937$. We assign this trend to a capture of Holocene river-borne terrigenous sediments on the upper continental slope, in contrast to an increased sediment transport across the upper slope during glacial low sea level, when the river mouths had shifted across the shelf, in part were probably deeply incised (Fig. 1), and larger portions of the sediment load bypassed our core transect.

East of Vietnam, the fairly similar $\delta^{18} \mathrm{O}$ records of cores 17954, 17955, and 17956 indicate stronger changes in sedimentation rates, ranging from 2 to $9 \mathrm{~cm} / \mathrm{ka}$ (Fig. 3a). In the southern SCS the benthic $\delta^{18} \mathrm{O}$ stratigraphy (Fig. 3c) results in sedimentation rates that vary from interglacial $7 \mathrm{~cm} / \mathrm{ka}$ to glacial $15 \mathrm{~cm} / \mathrm{ka}$ in core 17961 and reach up to 30-60 $\mathrm{cm} / \mathrm{ka}$ in (paleo-) nearshore core 17964, rates which are mainly produced by (hemipelagic) terrigenous sediment input. It is derived from the Indo-China Peninsula and the Indonesian Archipelago, especially, from the emerged Sunda shelf during Stage-2 and Stage-3 times of low sea level. 


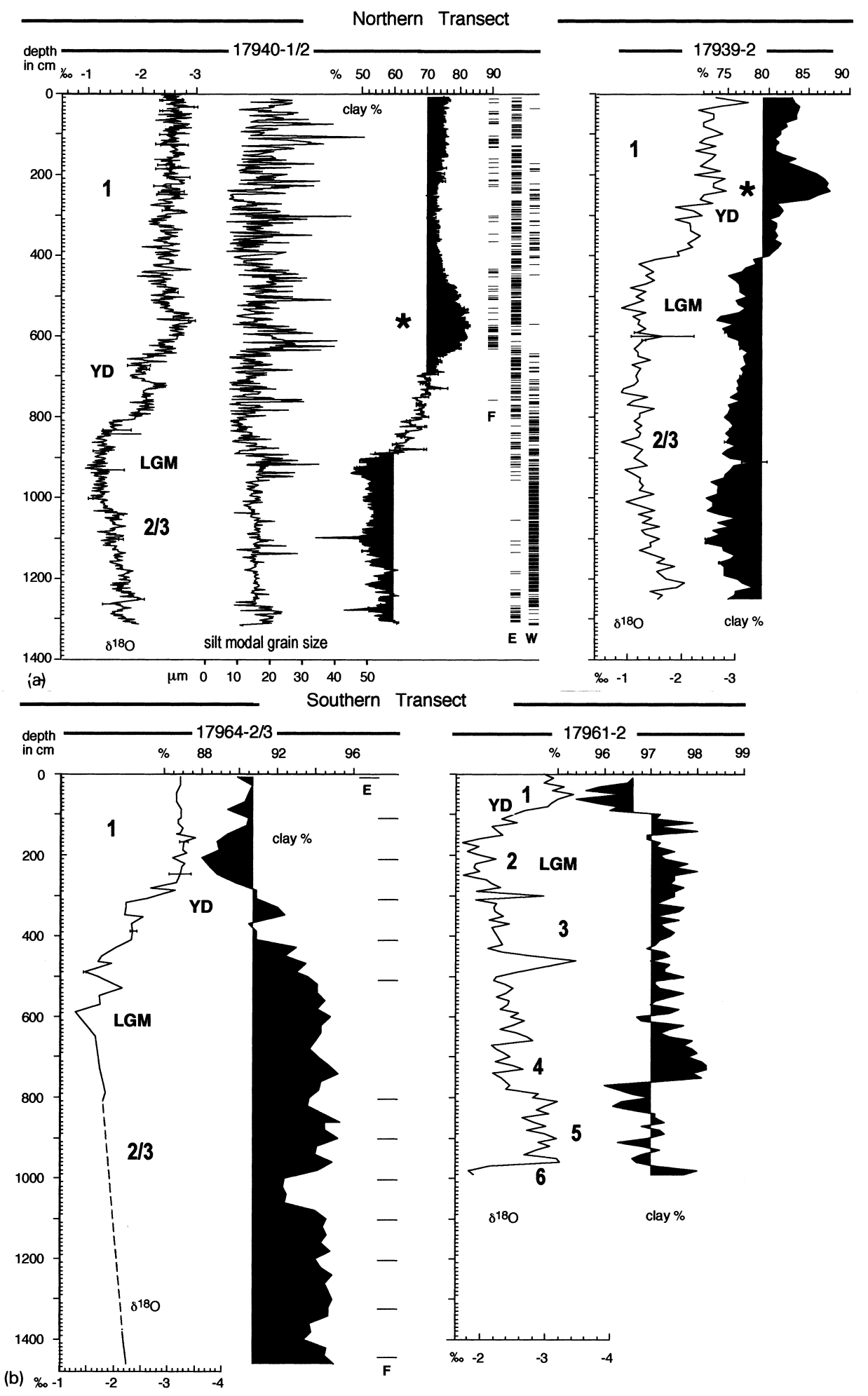




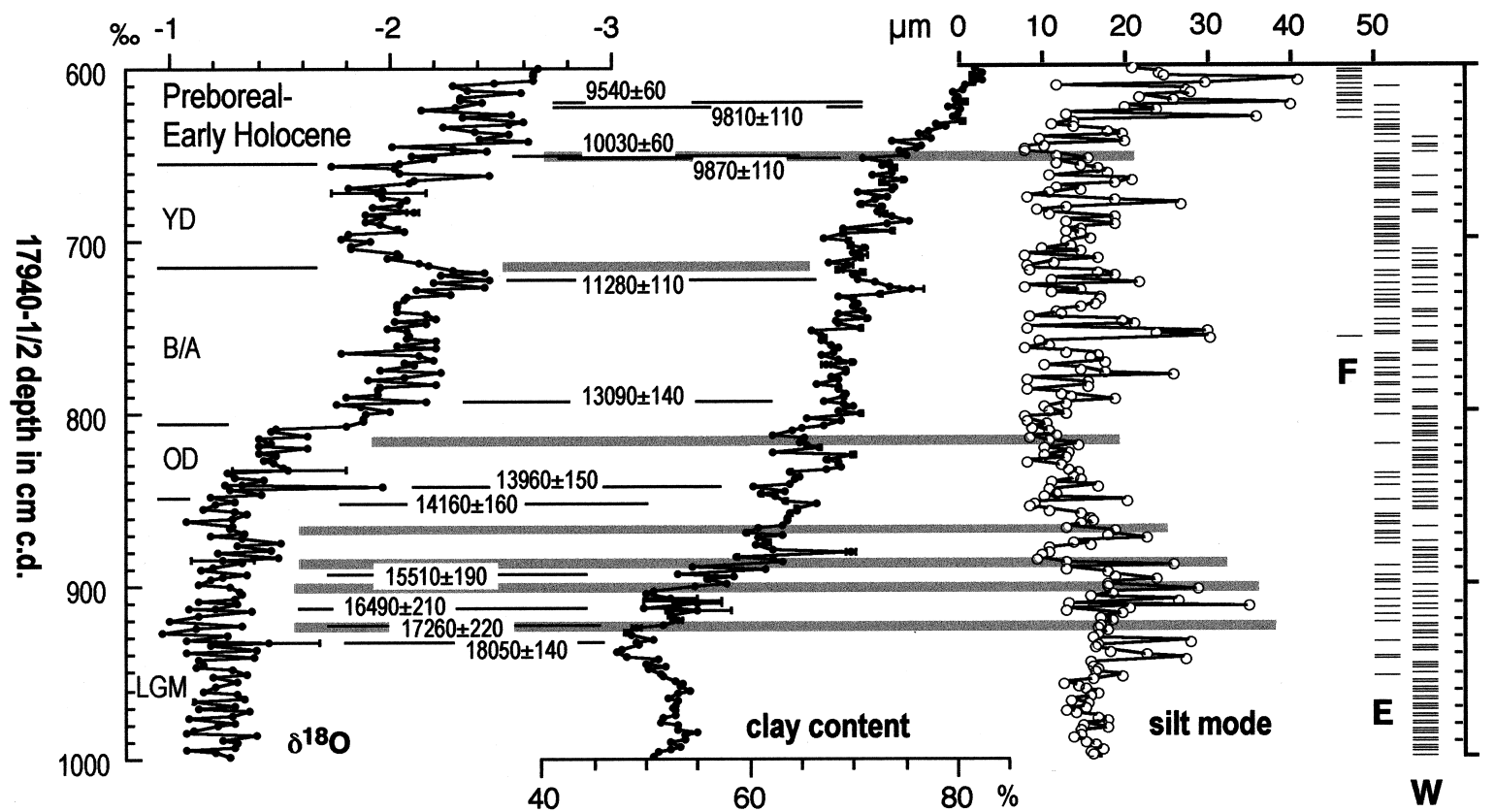

Fig. 7. Close-up of variations in terrigenic sediment input across the last deglaciation $(600-1000 \mathrm{~cm}$ c.d.) in core 17940 as compared to the planktonic $\delta^{18} \mathrm{O}$ record. Siliciclastic modal grain sizes $(>6 \mu \mathrm{m})$ of dust stand for paleowind strength during winter, clay contents reflect intensity of fluvial sediment input. Thin lines mark levels with AMS- ${ }^{14} \mathrm{C}$ dates, broad bars display major abrupt changes in the terrigenic sediment input and their linkage to $\delta^{18} \mathrm{O}$ stratigraphy $(L G M=$ Last Glacial Maximum; $O D=$ Oldest Dryas; $B / A=$ Bølling-Allerød; $Y D=$ Younger Dryas. Preboreal-early Holocene maximum in summer monsoon). Horizontal bars near to the right margin show winnowed $(W)$, eolian dust $(E)$, and fluvial mud $(F)$ deposits (based on Koopmann index; see Fig. 8B).

\subsection{Grain sizes of the siliciclastic sediment fraction}

Similar to the $\delta^{18} \mathrm{O}$ records, the grain-size curves of core 17940 are based on sample spacings of 2 $\mathrm{cm}$ equal to a time resolution of 20-50 years in the Holocene and about 80-100 years in the LGM and $\delta^{18} \mathrm{O}$ Stage 3. Sample intervals are $10 \mathrm{~cm}$ in cores 17939 and 17961 and $10-20 \mathrm{~cm}$ in core 17964 , resulting in an average time resolution of 500-1500 years over glacial and interglacial stages of the last 140,000 years (Fig. 6).
Grain sizes (\% clay $<6 \mu \mathrm{m}$ and the modal grain size of silt $>6 \mu \mathrm{m}$ ) were measured on the siliciclastic sediment fraction, i.e. on the carbonate-free fraction, still including a small but negligible portion of marine biogenic opal. In general, the clay fraction is dominating the hemipelagic sediment sections of the SCS (Fig. 6a). In core 17940, less pronounced in core 17939, the clay content varies significantly, with high values of $70-75 \%$ in the Holocene, a clear extreme of 75 to $>80 \%$ in the earliest Holocene, low values of $50-55 \%$ in the LGM, and striking

Fig. 6. (a) and (b). Percent clay $(<6.3 \mu \mathrm{m})$ and silt modal grain sizes $(6.3-63 \mu \mathrm{m})$ in the siliciclastic, carbonate-free fraction $(<63 \mu \mathrm{m})$ of hemipelagic sediments in core 17940 , supplemented by \% clay $(<6.3 \mu \mathrm{m})$ curves of cores 17939 (northern SCS), 17961 , and 17964 (southern SCS), where the silt fraction of many samples is partly too small for deducing an unequivocal silt grain-size mode. Horizontal bars along \% clay curves of cores 17940 and 17964 indicate dominance of eolian dust $(E)$, fluvial mud $(F)$, or winnowed deposits $(W)$, based on the Koopmann grain-size index (Fig. 8; see Section 4.1). The only volcanic ash layer in core 17940 occurs at $1098.5 \mathrm{~cm}$ c.d. $\delta^{18} \mathrm{O}$ curves are shown for stratigraphic reference $\left(L G M=\right.$ Last Glacial Maximum; $Y D=$ Younger Drays event; ${ }^{*}=$ Preboreal-early Holocene maximum in summer-monsoon humidity). 

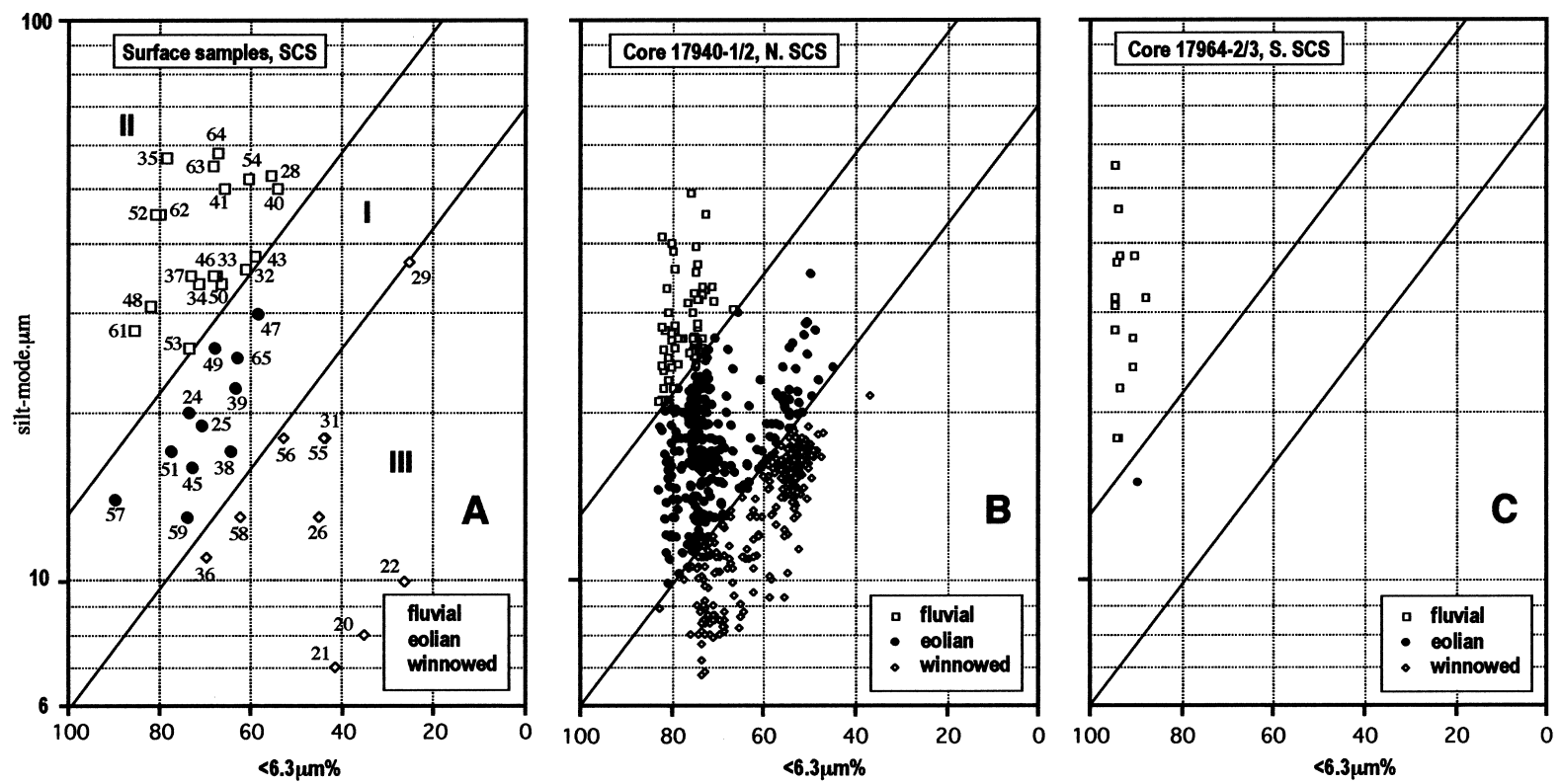

Fig. 8. Correlation of $\%$ clay plus fine silt $(<6.3 \mu \mathrm{m})$ versus silt modal grain sizes $(6.3-63 \mu \mathrm{m})$ in the siliciclastic, carbonate-free fraction $(<63 \mu \mathrm{m})$ of modern hemipelagic surface sediments in the SCS (A) (Grothmann, 1996) and cores 17940 (B) and 17964 (C). I $=$ group of samples from sea-floor elevations far from continental river discharge with a well sorted grain-size spectrum characteristic of eolian-dust input. $I I=$ group of samples with an excess in fine fraction relative to silt modal grain sizes characteristic of fluvial sediment discharge. $I I I=$ group of samples with a deficit in fine fraction relative to silt modal grain sizes, ascribed to volcanic ashes (samples 20-22) and sediment winnowing on the sea floor ('Koopmann index'; Koopmann, 1981). Numbers in (A) are sample numbers (Table 1).

short-term oscillations of $<50$ to $>60 \%$ in late Stage 3 . These changes generally parallel the $\delta^{18} \mathrm{O}$ record, except for the end of the LGM (Stage 2). Here the marked increase in clay content from $<50$ to $>60 \%$ begins prior to the onset of glacial Termination Ia in the $\delta^{18} \mathrm{O}$ record. The time lag amounts to almost $4000{ }^{14} \mathrm{C}$ years $(926$ vs. $850 \mathrm{~cm}$ c.d. $=18.0-17.26$ ka vs. 14.16 ka; Figs. 6 and 7).

In core 17940 the primary modal grain sizes of silt $>6 \mu \mathrm{m}$ are fairly stable in Stage-3 and -2 samples (about $16 \mu \mathrm{m}$ at $950-1300 \mathrm{~cm}$ c.d.). The modes reach maxima of 20-30 $\mu \mathrm{m}$ near the end of the LGM (near $910 \mathrm{~cm} \mathrm{c.d.)} \mathrm{and} \mathrm{decrease} \mathrm{to} \mathrm{about} 10 \mu \mathrm{m}$ at $800 \mathrm{~cm}$ c.d. (near the start of the Bølling). Further upcore, they are highly variable over deglacial and Holocene times (in the top $800 \mathrm{~cm} \mathrm{c.d.)} \mathrm{without}$ revealing a significant trend. In part, this variability is an artifact, linked to problems in identifying the primary silt grain-size modes, once the silt fraction is very small. The grain-size curve of the more distal core 17939 runs largely parallel to those of core 17940 over glacial and interglacial times. However, increasing offshore distance and water depth result in a systematic loss of coarser, silt-sized grains and a rise in the clay content by $2-20 \%$ between sites 17940 and 17939 (Fig. 6a).

The siliciclastic silt fractions exceed $60 \%$ at 1098 cm c.d. in core 17940 (about 30,000 calendar years) and at $780 \mathrm{~cm}$ c.d. in core 17961 (about 75,000 calendar years). These silt layers were identified under the microscope as volcanic ash deposits.

In the southern SCS, the percentages of clay in cores 17961 an 17964 just reveal a reversed trend (Fig. 6b). Here the Holocene (and warm Stages 5.1-5.5) clay contents $<6 \mu \mathrm{m}$ only amount to 88 $91 \%$ at (paleo-nearshore) site 17964 and $96 \%$ at the more distal site 17961. In contrast to the northern SCS, they increase to $93-95 \%$ in core 17964 and to $97-98 \%$ in core 17961 during peak glacial and semiglacial Stages 2-4 (Fig. 6b; no silt modes were identified at site 17961). Note that the YD event in core 17964 from the southernmost SCS is reflected by a short-lasting, almost LGM-style, clay maximum (not resolved in core 17961). 


\subsection{Sea-surface temperature records}

The SST records of cores 17940 and 17954 are based on both planktonic foraminifera (PF) census counts (PF-SST) and $\mathrm{U}_{37}^{\mathrm{K}}$ data $\left(\mathrm{U}_{37}^{\mathrm{K}} \mathrm{SST}\right)$. The SST records of cores 17927 and 17961 are derived from $\mathrm{U}_{37}^{\mathrm{K}}$ data only (Kirch, 1997; Pelejero et al., 1999). The $U_{37}^{K}$ SST records in Fig. 9 are calibrated to annual mean SST in 0-30 m water depth (Pelejero and Grimalt, 1997); the PF-based SST estimates are calibrated separately to winter and summer temperature values at 'the sea surface' (Thompson, 1981), the average of which is compared to the $\mathrm{U}_{37}^{\mathrm{K}} \mathrm{SST}$ data.

Previous studies using planktonic foraminifera records (Wang and Wang, 1990; Thunell et al., 1994) already noted that the glacial-to-interglacial variations of winter SST were much higher in the SCS than those found in the open West Pacific at similar latitudes. This difference implies a strongly increased local seasonality in the SCS during glacial periods.

Core 17940 provides the most detailed $\mathrm{U}_{37}^{\mathrm{K}}$ SST and PF-SST records over the last 40,000 years to estimate the climatic changes off South China (Fig. 9). Summer SST remained almost constant over the entire time span of the last glacial cycle. In contrast, the winter temperatures show a number of shortterm negative oscillations by about $\Delta 2^{\circ} \mathrm{C}$ during $\delta^{18} \mathrm{O}$ Stage 3. They just parallel the 'warm' $\delta^{18} \mathrm{O}$ minima. The SST minima during Stage 2 match high $\delta^{18} \mathrm{O}$ values and culminate near the end of the LGM. Later, the winter SST indicate a long-term

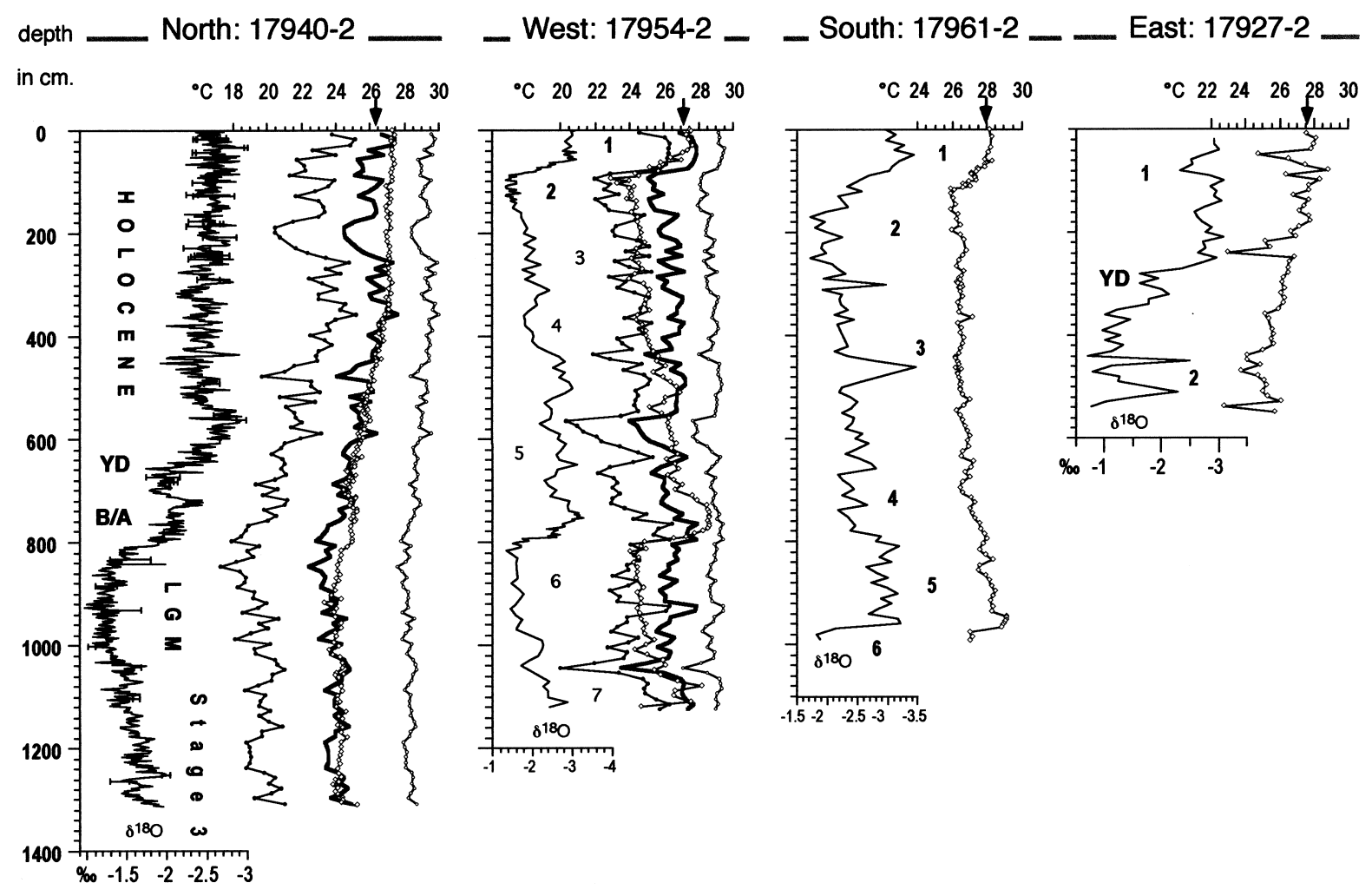

Fig. 9. Sea-surface temperature (SST) records from the northern (17940), western (17954), southern (17961), and eastern (17927) South China Sea. Circles and dots are SST estimates at $0 \mathrm{~m}$ depth for summer and winter, based on planktonic foraminifera counts (PF) (FP-12E transfer function of Thompson, 1981). Gray thick lines in cores 17940 and 17954 are annual mean SST based on the average of winter and summer PF-SST. Diamonds are annual mean SST values for 0-30 m depth, based on the $\mathrm{U}_{37}^{\mathrm{K}}$-index $\left(\mathrm{U}^{\mathrm{K}}{ }_{37}=0.36 T-0.056\right.$; Pelejero et al., 1999). $\delta^{18} \mathrm{O}$ curves serve for stratigraphic reference; bold numbers refer to $\delta^{18} \mathrm{O}$ stages; $Y D=$ Younger Dryas; $B / A=$ Bølling-Allerød. $\mathrm{U}_{37}^{\mathrm{K}}$-SST record of core 17927 from Kirch (1997). Arrows mark modern annual mean SST values at 0-30 m. 
(a)

depth

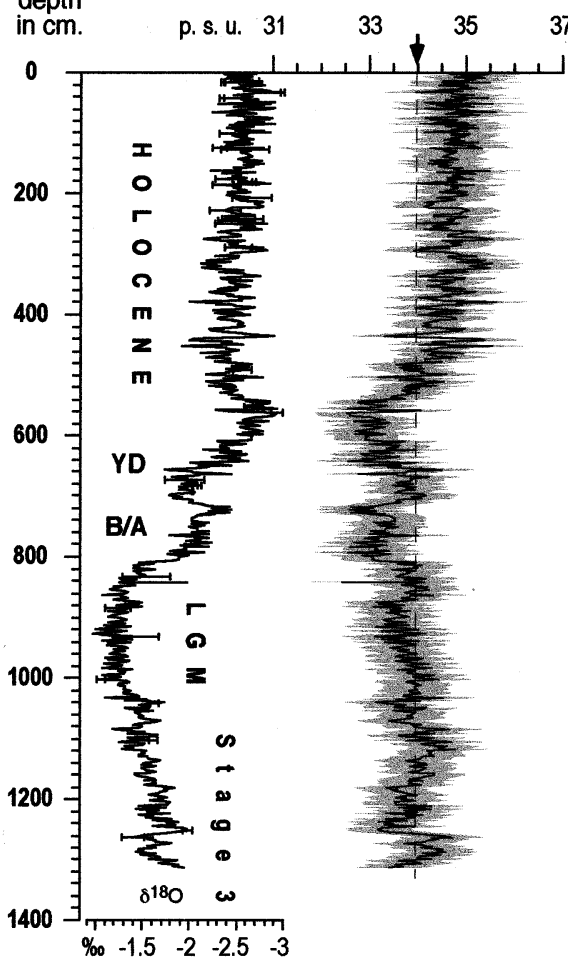

West: 17954-2

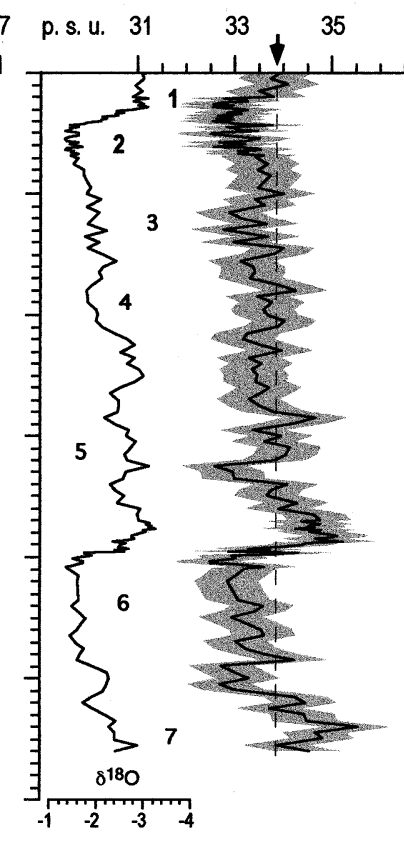

37 p. s. u.

South: 17961-2

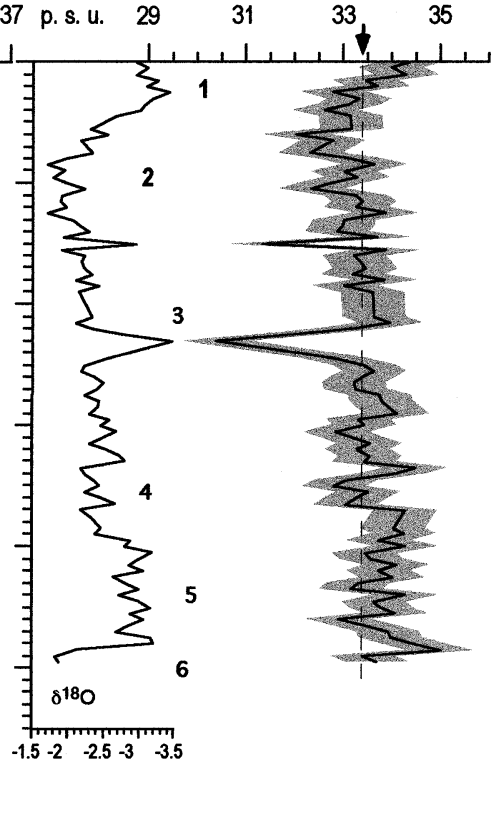

East: 17927-2

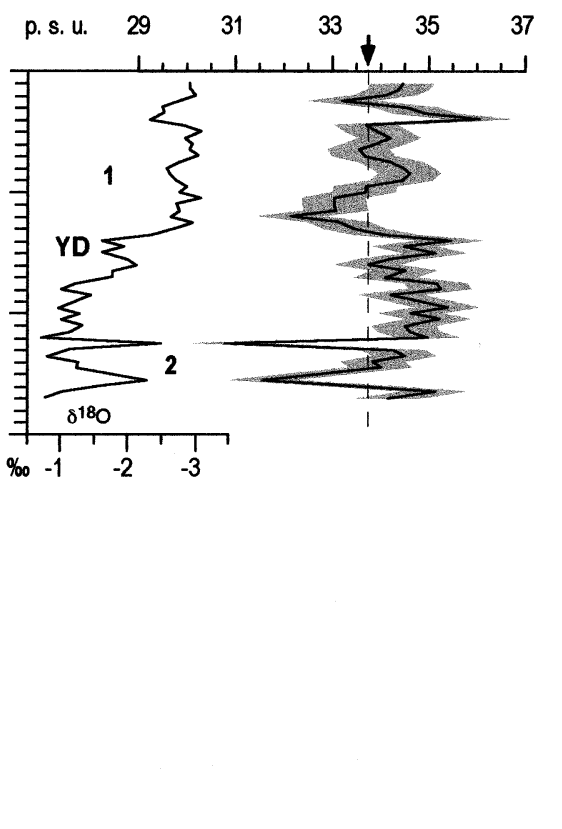

Fig. 10. (a) Sea-surface salinity (SSS) records covering up to 220,000 years in the South China Sea. Using the transfer equation of L. Wang et al. (1995), SSS values are calculated from (1) $\delta^{18} \mathrm{O}$ of Globigerinoides ruber after subtracting the global ice effect (Labeyrie et al., 1987; Vogelsang, 1990), and (2) U $\mathrm{U}_{37}^{\mathrm{K}}$-based estimates of annual mean SST for $0-30 \mathrm{~m}$ (Fig. 9). $\delta^{18} \mathrm{O}$ curves serve for stratigraphic reference; bold numbers refer to $\delta^{18} \mathrm{O}$ stages; $Y D=$ Younger Dryas; $B / A=\mathrm{B} \emptyset 1$ ling-Allerød. SSS record of core 17927 based on Kirch (1997). Vertical arrows mark modern mean SSS (0-30 m). 


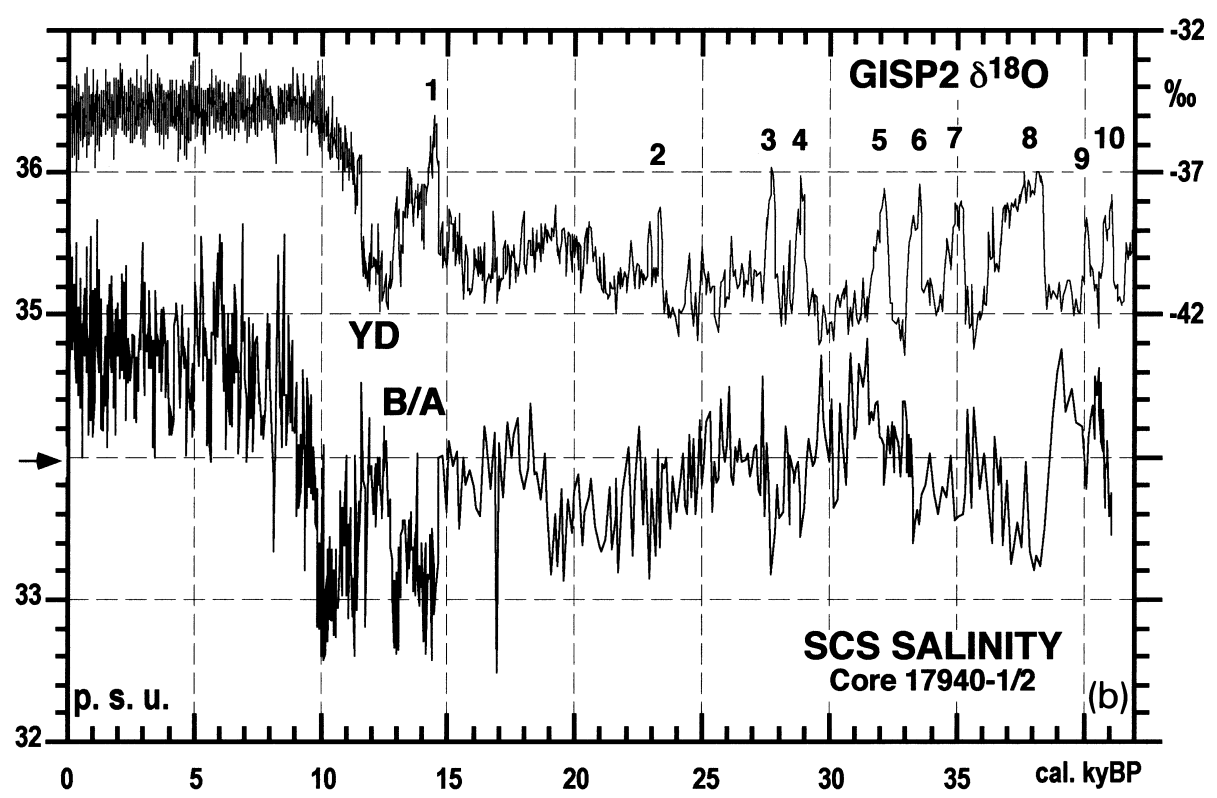

Fig. 10 (continued). (b) Close-up of SSS variations at site 17940 , which are generally reversed to the $\delta^{18} \mathrm{O}$-temperature oscillations in the GISP2 ice record (Grootes and Stuiver, 1997). Numbers are Dansgaard-Oeschger events.

gradual warming until the middle Holocene, about 6000 calendar years (at $360 \mathrm{~cm}$ c.d.). This long-term trend was interrupted several times by short cooling episodes, an unexpected one in the Bølling, one less spectacular in the YD, and an especially marked episode in the early Holocene, about 8200 calendar years $(480 \mathrm{~cm}$ c.d.). Prominent depressions of winter SST also occur in the late Holocene $(240-180 \mathrm{~cm}$ c.d. and 95-55 cm c.d.), about 5.2-3.4 and 2.0-1.0 thousand calendar years ago. As predicted, the major and minor minima in winter SST indeed involve maxima in seasonality.

The temperature variations off South Vietnam (core 17954; Fig. 9) closely resemble the variability found off Hong Kong. Most salient minima in winter temperature (shifts reaching $3-6^{\circ} \mathrm{C}$ ) and maxima in seasonality occurred during Stage 2 , several times during Stage 3, earliest Stage 4, Stages 5.2 (!), 5.4, and 6.2-6.4, and particularly strong at the onset of Stage 6.6. During warm Stage 5.5 the $\mathrm{U}_{37}^{\mathrm{K}} \mathrm{SST}$ estimates exceeded the Holocene values by about $1.0^{\circ} \mathrm{C}$.

West of Luzon (core 17927; Fig. 9) the $\mathrm{U}_{37}^{\mathrm{K}} \mathrm{SST}$ estimates show a gradual increase by about $4^{\circ} \mathrm{C}$ from glacial Stage 2 to the middle Holocene, with a short-term but pronounced cooling by $4^{\circ} \mathrm{C}$ in the earliest Holocene (at 200-230 cm core depth).
In the southern SCS (core 17961; Fig. 9) the longterm annual $\mathrm{U}_{37}^{\mathrm{K}} \mathrm{SST}$ variations did not exceed $3^{\circ} \mathrm{C}$. Note that the SST values of the warm Eemian Stage 5.5 were about $1^{\circ} \mathrm{C}$ higher than during the Holocene, similar to the $\mathrm{U}_{37}^{\mathrm{K}}$ SST record off Vietnam. Hence this feature may be of general climatic significance in the SCS.

\subsection{Sea-surface salinity records}

Past SSS variations in the northern, western, southern, and eastern SCS (Fig. 10) range from about 30 to $36 \%$ over interglacial-to-glacial times. Especially, SSS changes mark some extremely shortlasting, millennial-scale events that form a sensitive record of changes in monsoon moisture along the margins of the SCS.

\section{Discussion: past variations in East Asian monsoon}

\subsection{Records of continental wetness and aridity}

Variations in the intensity of wet summer and dry winter monsoon are deduced from the history of 

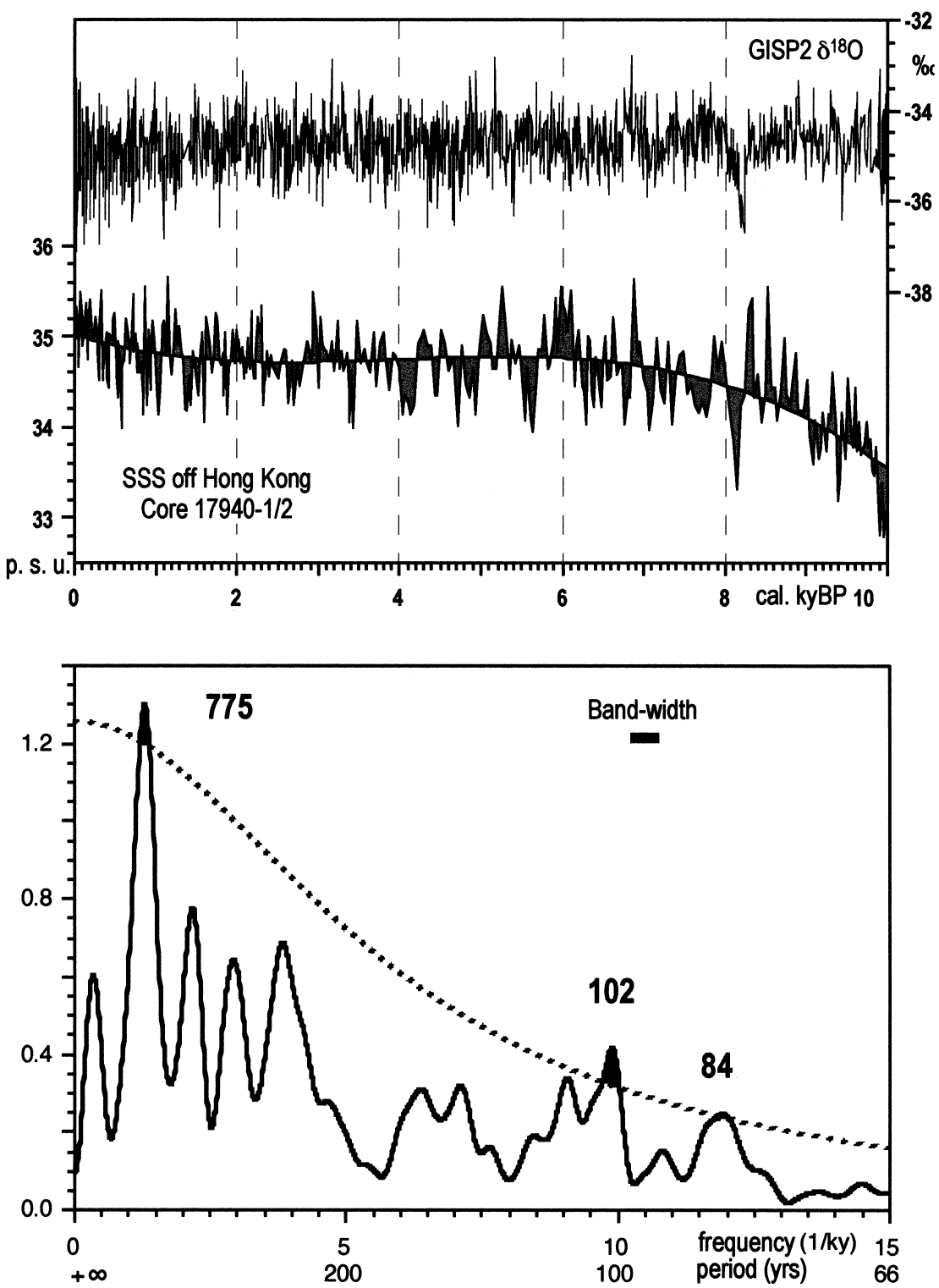

Fig. 11. Holocene changes in $\delta^{18} \mathrm{O}$-based temperature record of Greenland ice-core GISP2 (Grootes and Stuiver, 1997) versus sea-surface salinity (SSS) changes at site 17940 off Hong Kong over the last 10,000 years. Origin of SSS record as in Fig. 10. Data are presented in the time (upper panel) and frequency domain (lower panel). Major temperature lows $\left(\delta^{18} \mathrm{O}\right.$ minima) on Greenland summit were coeval with SSS maxima, equal to lows and subsequent highs in monsoon precipitation in subtropical South China (e.g. at the end of the Preboreal maximum in summer monsoon, about $8250 \mathrm{yr}$ BP). During the last 400 years, since the onset of the Little Ice Age, a drop in monsoon precipitation parallels growing amplitudes of $\delta^{18} \mathrm{O}$ fluctuations in the ice record. For spectral analysis (Blackman-Tukey method; AnalySerie program of Paillard et al., 1996) the SSS record was detrended by a third-polynomial fit (upper panel) and spline interpolated on equidistant steps of 30 years with $25 \%$ lag. Horizontal bar shows band-width. Numbers in the SSS power spectrum are significant periods in years, which exceed the upper limit of red noise at $80 \%$ confidence level (dotted line). 
continental aridity in South China, which in turn is controlling the fluvial and/or eolian sediment supply to the continental margin in front of the Pearl River mouth, southeast of Hong Kong. Here the hemipelagic sediments in cores 17939 and 17940 contain a detailed record of past changes in the eolian and fluvial sediment input. In a first approximation, we distinguish the two different sources by a simple empirical relationship between the percentage of siliciclastic fine fraction $(<6 \mu \mathrm{m})$ and the primary modal grain size of siliciclastic silt $(>6 \mu \mathrm{m})$, as shown in the diagrams of Fig. 8. This approach was successfully defined and employed by Koopmann (1981; modified by Stein, 1985) for deposits along the West African continental margin and so far presents the only semiquantitative, hence crucial measure for separating dominantly eolo- from fluviomarine samples in a hemipelagic sediment record. Our records of past changes in aridity and wetness on the mainland next to the SCS are supported by independent evidence from pollen (Sun and Li, 1999) and paleosalinity (SSS) data. Silt modal grain sizes form also a measure of past wind strengths (Sarnthein et al., 1981), in our case, of the winter monsoon that carries the eolian loess to the SCS.

In the Koopmann diagram of modern surface sediments in the SCS (Figs. 1 and 8A; Grothmann, 1996) only few samples occupy Field I. They largely stem from elevated sea-floor positions distal to river mouths, such as the central reef platform, or from locations that are secluded from fluvial supply in the nepheloid layer by (small-scale) ridges and trenches. In Field I the grain-size modes of silt increase with decreasing clay contents, hence are well sorted and typical of eolian-dust transport. However, more hemipelagic sediment samples from the northern and southern SCS show an excess in clay fraction $<6$ $\mu \mathrm{m}$ relative to silt-modal grain sizes and occupy Field II in Fig. 8A. As defined by Koopmann (1981), this excess is characteristic of fluvial sediment input. Off Hong Kong, the abundant clay deposits on the upper continental margin may largely originate from the Pearl River which ranks as the second largest river of China in water discharge $\left(320 \mathrm{~km}^{3} / \mathrm{yr}\right.$; next to the Yangtze River) and has a modern catchment area of about $442,600 \mathrm{~km}^{2}$. It is subject to intensive monsoon precipitation during summer, resulting in an annual sediment load of 11 billion tons (Zhang et al., 1994). Finally, grain-size Field III (Fig. 8A) groups sediment samples with a relative deficit in clay, indicative of both volcanic ashes (samples 20, $21,22)$ and a loss of fine sediments due to winnowing near the sea floor (samples 26, 31,36, 55, 56, 58).

Both the distribution of these three grain-size groups in core 17940 and the prominent rise in \% clay in cores $17940(<630 \mathrm{~cm})$ and $17939(<270$ $\mathrm{cm}$; Figs. 6-8) show that the supply of fluvial sediments in the northern SCS was largely confined to the Holocene and a short precursor signal in the Bølling (at $755 \mathrm{~cm}$ depth). The sediment records imply (1) a sudden increase in summer-monsoon rains right after the $\mathrm{YD}$, which developed over less than few decades, (2) maximum rains during the Preboreal and earliest Holocene, and (3) a modest decrease in precipitation subsequent to the early Holocene clay maximum. A very first postglacial increase in clay content in cores $17939(<425 \mathrm{~cm})$ and $17940(<920 \mathrm{~cm})$ already occurred as early as $18,000{ }^{14} \mathrm{C}$ years, which implies that modest fluvial input and monsoon rains began much earlier than the Bølling.

The broad Preboreal-early Holocene maximum in runoff and precipitation in China goes along with a marked minimum in sea-surface salinity (SSS) in the western and northern SCS, most pronounced at site 17940 in front of the Pearl River (Fig. 10). The SSS minimum clearly derives from a $\delta^{18} \mathrm{O}$ minimum (Figs. 3 and 4) and conjugate low $\mathrm{U}_{37}^{\mathrm{K}}$ SST values during that time (Fig. 9). Off Hong Kong the salinity reduction reached down to $32.6 \%$ and thus can hardly stem from an inflow of West Pacific water but was necessarily linked to enhanced local precipitation during summer. These rains imply a strongly intensified summer monsoon that carried more marine moisture into subtropical South China. The timing of this event is coeval with an early Holocene maximum in monsoon precipitation which occurred in the countries encompassing the Arabian Sea (Sirocko et al., 1993). This synchroneity suggests a hemisphere-wide joint forcing of long-term (and short-term) changes in the hydrological cycle of the Asian monsoon. In the western and southern SCS also cores 17954, -56, and -61 show a distinct $\delta^{18} \mathrm{O}$-freshwater signal during the earliest Holocene, possibly linked to an enhanced runoff of the Mekong 
River (Fig. 1). In other cores (Fig. 3a and Fig. 10) the signal is less significant, partly because of lower sampling resolution, partly because of core locations that are too distant from the major river mouths.

In contrast to the last 14,600 calendar years, early Termination IA and $\delta^{18} \mathrm{O}$ Stages 2 and 3 in core 17940 are free of (hemipelagic) fluvial deposits but dominated by eolian-dust discharge and sediment winnowing (Fig. 6a and Fig. 7; Field-I and -III samples only in Fig. 8B). Downslope winnowing is also reflected by an increased lateral supply of shallowwater ostracods (Zhou and Zhao, 1999) and possibly, by the extremely low clay content. In part, the absence of riverine sediments off Hong Kong during the LGM may result from the local morphology of the continental slope (Fig. 1). Here the glacial low sea level has led to a significant downcutting of the Pearl River mouth. Accordingly, any potential fluvial sediment discharge may have bypassed our core transect via canyons across the slope farther to the west and may be better encountered in the cores near the base of the slope.

Nevertheless, the joint lack of fluvial sediments and massive eolian-dust supply at core site 17940 during the LGM together form a substantial record of continental aridity in South China. This conclusion is corroborated by further evidence.

(1) During Stages 2 and 3 the grain-size modes of silt amounted to 15-20 $\mu \mathrm{m}$ (Fig. 7; core 17940), values that are characteristic of loess deposits in Central China (Xiao et al., 1995; Porter and An, 1995). Near $18,000{ }^{14} \mathrm{C}$ years $(940-890 \mathrm{~cm}$ c.d.), coeval with the solar insolation minimum and peak LGM about 21,000 calendar years, the grain-size modes reach 25-30 $\mu \mathrm{m}$ and depict a clear maximum in the strength of winter monsoon.

(2) The dominance of pollen from semiarid and Alpine regions at site 17940 (Sun and $\mathrm{Li}, 1999$ ) demonstrates that the LGM pollen were dust-borne, originating from regions in (South) China that were dry and cold.

(3) During the LGM the SSS values at site 17940 were indeed 1.0-1.5\% lower than today, pretending more wetness. However, they were $>1 \%$ o higher than during Termination I, 14.6-9.5 thousand calendar years ago (Fig. 10b). Since the glacial Pearl River mouth moved very close to site 17940 across the emerged broad shelf with the low sea level (Fig. 1), this sums up to a major drop in fluvial runoff from South China.

In summary, the great contrasts between glacial and interglacial sediment records imply a fundamental change in the climate of China, a switch from the glacial dominance of winter monsoon to a dominance of summer monsoon. Its close ties to the Bølling and Holocene climate may also involve that typhoon storms in South China are a feature characteristic of interglacials and rare during glacials.

During Stage 3 short-term and coherent oscillations of SSS and the clay fraction in core 17940 (below $1050 \mathrm{~cm}$ c.d.) record a monsoon climate over South China, that was highly variable on short time scales, per analogy to the loess record of Porter and An (1995). At 1260-1300 cm c.d. the strong concentration of eolian dust, coarsened modal grain sizes, and a salient clay minimum match a marked SSS maximum (Fig. 6a and Fig. 10b), hence document a peak in aridity. It was dated to about 35,000 ${ }^{14} \mathrm{C}$ years and tentatively assigned to (cold) Heinrich event 4 (Bond and Lotti, 1995) (Fig. 4). Directly subsequent (at 1260-1230 cm c.d.), a lack of eolian-dust samples, increased clay, and markedly reduced SSS values record a phase of humid climate linked to the (warm) Dansgaard-Oeschger event 8. Similar but less conspicuous oscillations of climate occur in core 17940 near $1110 \mathrm{~cm}$ c.d. (Figs. 4 and 6a) and may be linked to Heinrich event 3 and Dansgaard-Oeschger event 4 (about 25,000 ${ }^{14} \mathrm{C}$ years). Per analogy with the Bølling-YD-Preboreal oscillation we conclude that also the short events of continental aridity in China were tied to events of global cooling and vice versa, phases of continental humidity to global warmings on millennial and shorter time scales, i.e. to the Dansgaard-Oeschger events.

In the tropical southern SCS (cores V35-5, 17961, and 17964) the interglacial-to-glacial changes in terrigenic sediment supply and paleoceanography were equally affected by changes in sea level and climate. The glacial lowering of the sea level down to about $-120 \mathrm{~m}$ led to (1) an emerged Sunda shelf, (2) a shift of its shoreline to the vicinity of site 17964 (Fig. 1), and (3) the creation of two major, Amazone-style tropical river deltas at the shelf margin, linked to the Mekong and Molengraaff rivers (Evans et al., 1995; Stattegger et al., 1997). These great shifts in shoreline and fluvial discharge may readily explain (1) 
an abrupt, but long-lasting increase in sedimentation rates and \% siliciclastic clay at the Stage 5-Stage 4 boundary, and (2) the abrupt decrease in \% clay and sedimentation rates (by a factor of 2) at both glacial Termination II and the end of the YD (Fig. 6b; cores 17961 and 17964).

The siliciclastic sediment fraction hardly contains any short-term signals of climatic change during Stages 2-4. Short-term variations in clay content $(<6 \mu \mathrm{m})$ did not exceed $1 \%$ at site 17961 (at a level of 97\%) and 2\% at site 17964 (at a level of $74 \%$; Fig. 6b) which occurred close to the shoreline at low sea level. In a Koopmann diagram (Fig. 8C) the Stages 1-2 grain-size data of core 19764 occupy Field I only, with a relative excess in clay (except for an eolian origin of the core-top sample). It implies a persisting riverine origin of the terrigenous sediment fraction near the Equator $\left(5^{\circ} \mathrm{N}\right)$ during glacial and interglacial times.

This uniformity entails that fluvial runoff and possibly, tropical conditions continued on the emerged Sunda subcontinent during glacial times, an important contribution to the current debate, where to find — on a global scale — the major glacial refuges of tropical forest (Prentice and Sarnthein, 1993). The model of a tropical rainforest on the glacial Sunda shelf is strongly supported by the pollen assemblage from the glacial section of core 17964 (X. Sun, pers. commun., 1997).

However, the simple model of purely sealevel-induced changes in freshwater discharge can hardly explain many long-term changes in paleosalinity found in core 17961 from the southern SCS (Figs. 1 and 10a). At this more distal site, SSS values have decreased by up to $2 \%$ only during and subsequent to the LGM. This SSS low documents a freshwater lid that culminated during Termination I and the earliest Holocene, just in contrast to the coeval sea-level rise and flooding of the Sunda shelf. Likewise, the great sea-level fall during early glacial Stage 4 did not induce the expected salinity reduction which occurred only later in Stages 4 and 3.3. On the other hand, the SSS values indeed increased during Termination II and reached the expected maximum along with the high sea-level stand of Stage 5.5, such as in the late Holocene. In conclusion, the long-term glacial-to-interglacial variations in tropical moisture are not yet fully understood.
The same problem applies to some prominent but very short-lasting changes in the tropical freshwater balance, which result from the paleosalinity record of core 17961. Here the $\delta^{18} \mathrm{O}$ record defines two major salinity reductions by almost $4 \%$ o near 25 and $34-40$ thousand ${ }^{14} \mathrm{C}$ years (Fig. 3a and Fig. 10). Unfortunately, the dating precision is still insufficient because of the unknown local ${ }^{14} \mathrm{C}$-reservoir effect in the glacial SCS. Hence the major question remains unsolved, whether these events were linked to (cold) Heinrich events 3 and 4 or, more likely, rather to the subsequent warm Dansgaard-Oeschger events 4 and 8 . The answer will be crucial for assessing the tropical moisture budget in the Asian monsoon region, also for extending or limiting the early findings of Duplessy et al. (1981), which suggested a concentration of the LGM monsoon precipitation to the equatorial Indian Ocean.

\subsection{Six premises on glacial-to-interglacial changes and short-term variability of the South China Sea}

Published data (e.g. CLIMAP project members, 1981; Wang and Wang, 1990; P. Wang et al., 1995; Metzger and Hurlbert, 1996) suggest a number of features in SCS paleoceanography during cool and glacial stages, that may be tested by means of our proxy data.

(1) At any sea-level drop exceeding $40 \mathrm{~m}$, as from the base of Stage 4 until the end of the YD (Chappell et al., 1996), the Borneo sea strait was closed and the presently important inflow of warm surface water from the equatorial West Pacific cut off; hence the SCS basin turned into a semiclosed 'sack system' (Fig. 1).

(2) By its potentially estuarine circulation the isolated inner SCS may have been highly sensitive to oxygen depletion, enhanced by any minor increase in freshwater input. The sensitivity was increased by the specific back-arc setting of the emerged broad Sunda shelf, which directed an immense continental runoff to the east, into the SCS, including the Mekong River from the eastern Himalayas.

(3) During glacial winter a stronger northerly monsoon may result in intensified anti-clockwise surface circulation along with an enhanced inflow of cooler water through the Luzon strait and a strong SST drop off South China. Here no upwelling is 
conceivable, definitely however, near the northern tip of Luzon (Ekman pumping).

(4) Wind-driven variations in the inflow of surface/subsurface water from the W. Pacific may also control intra-Holocene shifts in the oceanography of the SCS.

(5) The decreased glacial summer monsoon possibly was still sufficient for driving a weak clockwise circulation, which implies warm tropical summer SST off South China such as today, a strong seasonality, and a persisting but reduced upwelling intensity southeast of Vietnam (Fig. 1).

(6) Off South China the nutrients in glacial surface water were probably enriched by both eoliandust discharge and an enhanced inflow of upwelled nutrient-rich water through the Luzon strait during winter. In the central SCS we may expect a decrease in nutrients during glacial summer because of reduced monsoon and upwelling intensity. In contrast, plenty of nutrients may derive from the tropical Mekong and Molengraaff rivers near the southwestern margin of the SCS.

\subsection{Changes in monsoon-driven deep- and surface-water oceanography}

Premises 1 and 2. As soon as the sea level dropped by more than $40 \mathrm{~m}$, the SCS turned into a largely separate estuarine basin that indeed was highly susceptible to oxygen depletion below the mixed surface layer. An estuarine circulation also characterizes the modern and early Holocene SCS, as shown by low epibenthic $\delta^{13} \mathrm{C}$ values near $0 \%$ in the southern SCS at $1550 \mathrm{~m}$ water depth (core 17964; Fig. 3c). These values are similar to the $\delta^{13} \mathrm{C}$ signature of lower intermediate water (Sarnthein et al., 1988) that debouches from the West Pacific into the SCS. During Stage 2 the epibenthic $\delta^{13} \mathrm{C}$ values dropped to -0.5 to $-1.6 \%$ directly in front of the emerged Sunda shelf (core 17964; Fig. 3c). This $\delta^{13} \mathrm{C}$ range was lower than almost everywhere else in the glacial ocean (Sarnthein et al., 1988, 1994b), including the well-known glacial $\delta^{13} \mathrm{C}$ minima in the deep southern Indian Ocean (down to $-1.0 \%$; Rosenthal et al., 1997) and along the northern margin of the SCS at $1700-3800 \mathrm{~m}$ depth $(0$ to $-0.8 \%$ o in core 17940 in Fig. 3c; more data in Winn et al., 1992). From these benthic $\delta^{13} \mathrm{C}$ values we infer an extreme oxy- gen-minimum layer that developed near the southern margin of the SCS during glacial and cold Stages 2-4 and 6 and conclude on a stable estuarine stratification of the surface water in conjunction with high fluxes of organic carbon (Kienast, 1996). This model is in line with the coeval extensive tropical runoff deduced from both the ongoing deposition of hemipelagic fluvial sediments at sites 17961 and 17964 and, especially, from the extreme low-salinity spikes at site 17961 during late Stage 2 and Stage 3, discussed above (Fig. 6b and Fig. 10).

Premises 3 and 5. Glacial-to-interglacial changes in sea-surface temperatures of the SCS (Fig. 9) basically confirm the changes predicted from the strengthened seasonality of glacial monsoon winds and vice versa, from the interglacial drop in wind seasonality. The SST estimates based on PF counts indeed were almost constant during glacial and interglacial summer near the northern and western margin of the SCS, likewise in the southeastern sector (Miao and Thunell, 1994). In contrast, winter SST dropped all over the SCS by $4-7^{\circ} \mathrm{C}$ during glacial times.

By contrast to PF-based SST values, the $\mathrm{U}_{37}^{\mathrm{K}}$-based estimates of annual mean SST (at 0 $30 \mathrm{~m}$ ) only depict the general interglacial-to-glacial decrease in SST, from $27.5^{\circ} \mathrm{C}$ to $\sim 24^{\circ} \mathrm{C}$ in the north, from $27.5^{\circ}-28.5^{\circ} \mathrm{C}$ to $\sim 24^{\circ} \mathrm{C}$ in the west, from $28^{\circ}-$ $29^{\circ} \mathrm{C}$ to $\sim 26^{\circ} \mathrm{C}$ in the south, and from $27.5-29^{\circ} \mathrm{C}$ to $\sim 24^{\circ} \mathrm{C}$ in the east (Figs. 1 and 9). Altogether, the glacial-to-Holocene anomalies of annual mean SST decrease from $\sim 4-5^{\circ} \mathrm{C}$ in the north, east, and west to $<3^{\circ} \mathrm{C}$ in the south.

A closer inspection of the differences between the records of annual mean SST deduced from PF counts and from $\mathrm{U}_{37}^{\mathrm{K}}$ provide some important insights into the variable relative importance of past SST seasons for the formation of the $\mathrm{U}_{37}^{\mathrm{K}}$ signal in coccolithophores. In the northern SCS (core 17940; Fig. 9), $\mathrm{U}_{37}^{\mathrm{K}}$-based SST simply match the annual means calculated from PF-based SST values for summer and winter during the Holocene and Late Pleistocene (but exceed the actual modern SST value by almost $1^{\circ} \mathrm{C}$ ). In core 17954 (Fig. 9) just the late Holocene $\mathrm{U}_{37}^{\mathrm{K}}$-based SST values match the PF-based estimates of annual SST. However, the $\mathrm{U}_{37}^{\mathrm{K}}$-based SST come near to the PF-based winter SST during the last glacial and near to PF-based estimates for summer SST during the Eemian warm Stage 5.5. 
The differential affinity of $\mathrm{U}_{37}^{\mathrm{K}}$-based annual mean SST to summer, winter, or mean PF-SST may have different reasons. On the one hand, the variations may reflect strongly different accentuated bloom seasons of coccolithophores, linked to strongly differential nutrient fluxes (see premise 6). On the other hand, the differential affinity of the $\mathrm{U}_{37}^{\mathrm{K}}$ signal may result from large-scale changes in the wind-driven lateral inflow of warm or cold water masses from outside the SCS.

Based on a recent calibration approach using 370 sediment and trap sites in the global ocean from $60^{\circ} \mathrm{S}$ to $60^{\circ} \mathrm{N}$ (Müller et al., 1997, 1998), the $\mathrm{U}_{37}^{\mathrm{K}}$ paleotemperature index revealed a generally excellent correlation with annual mean SST from 0 to 10 $\mathrm{m}$ water depth, but no discernible influence of the seasonality of primary production. Likewise, sediment-trap data from the SCS depict roughly equal fluxes of coccolithophores during both winter and summer monsoon, but no significant seasonal difference (Wiesner et al., 1996). Accordingly, we can hardly assign the past shifts in the seasonal affinity of our $\mathrm{U}_{37^{\mathrm{K}}}^{\mathrm{K}} \mathrm{SST}$ data to potential changes in the seasonal nutrient level of surface water. This result especially affects the SST record of core 17954 from the outmost northern margin of the upwelling zone southeast of Vietnam (Figs. 1 and 9), where any interglacial strengthening of the summer monsoon and upwelling might indeed lead to a higher nutrient level than during winter and thus bias the $\mathrm{U}_{37}^{\mathrm{K}}$-based SST signal toward the summer season. However, the wind-induced upwelling will primarily result in a cooling of surface water, similar to that in the northern Arabian Sea, an effect just opposed to the overshoot in interglacial warming of $\mathrm{U}_{37}^{\mathrm{K}}$-based SST values (Fig. 9).

A comparison with the benthic $\delta^{18} \mathrm{O}$ record of global sea-level change (Labeyrie et al., 1987; similar to the $\delta^{18} \mathrm{O}$ record of core 17961, Fig. 3c) may help to constrain the actual changes in paleoceanography that finally controlled the enigmatic overshoots in warm and cold $\mathrm{U}_{37}^{\mathrm{K}}$-based annual mean SST at site 17954 (and 17961). Note that the warm 'overshoot' is strictly confined to the sea-level high stand of Stage $5.5(+6 \mathrm{~m})$, but does not match any particular maxima in PF-based mean SST (Fig. 9). During this time the summer inflow of warm surface water from the tropical West Pacific reached a maximum via the sea strait of Borneo such as today (Wyrtki, 1961). At site 17954 it probably suppressed any cooler SST signals entering from the West Pacific via the strait of Luzon during winter, possibly also at site 17961 . Vice versa, the $\mathrm{U}_{37}^{\mathrm{K}}$-based SST averages closely match the PF-based SST averages during Stages 5.4-5.1, when the sea level dropped and the diameter of the Borneo strait was reduced. Finally, the $\mathrm{U}_{37}^{\mathrm{K}}$-based SST averages shifted close to the PF-based winter values as soon as the strait was shut over Stages 4-2. During this time much cooler surface water prevailed in the whole SCS, in part probably advected from the upwelling cell near the northern tip of Luzon (Metzger and Hurlbert, 1996; Pflaumann and Jian, 1999; P. Wang et al., 1995), a mechanism also suggested by the increased nutrient content (see below).

In summary, the long-term interglacial-to-glacial variations in $\mathrm{U}_{37}^{\mathrm{K}}$-based annual mean SST in the SCS were also controlled by the major changes in sea level. They led to the closure and opening of the Borneo strait, thereby turning off and on the lateral inflow of warm surface water from the tropical Pacific (!). This advection competed with the incursion of cool surface water across the strait of Luzon along with the strengthened winter monsoon.

In contrast, the short-term, millennial-scale variations of PF-based and $\mathrm{U}_{37}^{\mathrm{K}}$-based SST show controversial trends, only little understood: winter SST in core 17940 (Figs. 4 and 9) just decreased during warm Dansgaard-Oeschger events 6-8 and the warm Bølling. Moreover, the warm Preboreal did not lead to the expected strong SST increase. In contrast, the SST values increased during cold Heinrich event 4 , but also along with the warm DansgaardOeschger events 3-4 and the Allerød. Three major coolings during the early and late Holocene (see below) occur in the PF-based SST records only. In part, these contradictions may be linked to the limits of the PF-12E transfer function employed (Pflaumann and Jian, 1999).

\subsection{Variations in the fertility of the South China Sea (premise 6)}

In modern sediments of the SCS the nutrient content of surface water is reflected in the planktonic $\delta^{13} \mathrm{C}$ record of G. ruber s.s. (white), while the nu- 

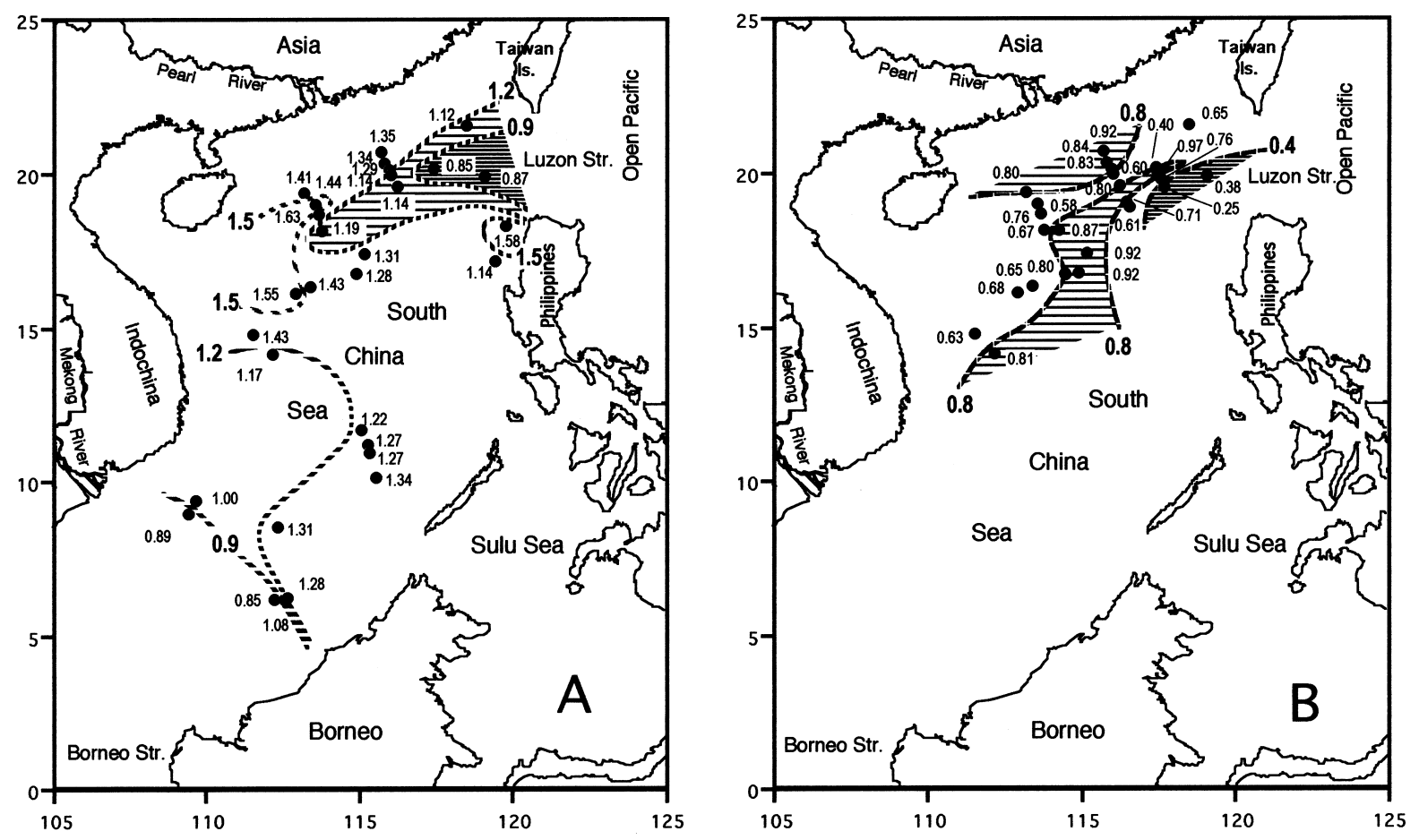

Fig. 12. Modern $\delta^{13}$ C-distribution patterns of G. ruber s.s. (white) (A) and P. obliquiloculata (B) (modified from Grothmann, 1996). Low $\delta^{13} \mathrm{C}$ values reflect high nutrient contents in surface $(G$. ruber) and subsurface water (P. obliquiloculata).

trient level of subsurface water is mirrored in the $\delta^{13} \mathrm{C}$ record of the subsurface dweller Pulleniatina obliquiloculata (Fig. 12A,B; Broecker and Peng, 1982; Sarnthein and Winn, 1990; Grothmann, 1996; Pflaumann and Jian, 1999). A tongue of low $\delta^{13} \mathrm{C}$ values of $G$. ruber $(<0.9 \%$ o) and P. obliquiloculata $(<0.4 \% o)$ traces the inflow of nutrient-enriched surface and subsurface water from the Luzon strait into the SCS. Today the flow advances along the continental margin of South China up to a position south of Hong Kong (Fig. 12A) and is linked to the winter monsoon (Metzger and Hurlbert, 1996). The rich nutrients of the flow originate from an upwelling cell near the north tip of Luzon, whereas the Kuroshio current is nutrient depleted.

A second $\delta^{13} \mathrm{C}$ low of $G$. ruber $(<1.2-<0.9 \%$ o) occurs south of Vietnam and depicts the nutrientenriched surface water in the upwelling belt, induced by the summer monsoon (Fig. 1; Wiesner et al., 1996). The $\delta^{13} \mathrm{C}$ minimum in the far southwest may be also linked to the prominent nutrient discharge of the Mekong and other tropical rivers. On the other hand, high $\delta^{13} \mathrm{C}$ values of $>1.3$ to $>1.5 \%$ o classify the surface water (but not the subsurface water) in the remaining parts of the SCS as largely nutrient depleted. Our coarse grid of modern $\delta^{13} \mathrm{C}$ data cannot detect any narrow-sized nearshore nutrient sources linked to rivers (during summer) and eolian dust (during winter) entering from the north and northwest.

However, as soon as the sea level dropped and the shoreline of China moved closer to shelf break, the variable local input of fluvial and eolian nutrients probably played a more important role in the nutrient budget of surface water at the proximal site 17940 (Fig. 3b and Fig. 12C). For example, low planktonic $\delta^{13} \mathrm{C}$ values depict extremely enriched nutrients during Termination I and the early Holocene. This fertility has triggered also a short-lasting extreme, organic-fluff-induced benthic $\delta^{13} \mathrm{C}$ minimum of $-1.4 \%$ (Fig. 3c). Based on the siliciclastic grainsize data (Fig. 6) we can ascribe this Preboreal event to outstanding runoff from the Pearl River.

Different from our expectation, the planktonic 


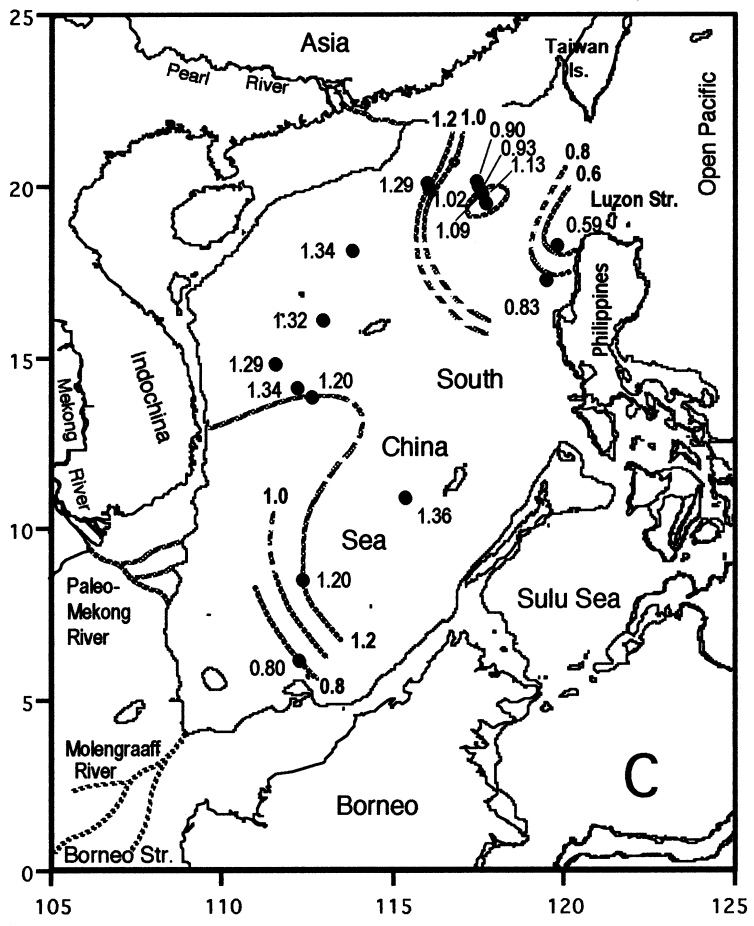

Fig. 12 (continued). (C) $\delta^{13} \mathrm{C}$-distribution pattern of $G$. ruber (white, s.s.) during the LGM (15-20 thousand ${ }^{14} \mathrm{C}$ years).

$\delta^{13} \mathrm{C}$ level at sites $17939 / 40$ was low also during glacial Stage 2. In part, this high nutrient level may stem from the massive input of glacial loess. On the other hand, the rich nutrients may reflect the intensified glacial inflow of nutrient-rich surface and sub-surface water from the Luzon strait during winter (Fig. 12C). However, this glacial nutrient inflow appears stronger diverted to the south along $\mathrm{Lu}$ zon (Thunell et al., 1992), away from the transect off Hong Kong. This finding is in line with the glacial SSS distribution (Fig. 10a), showing generally higher, i.e. 'Pacific', values near Luzon (core 17927: 34-35\%o) than off Hongkong (core 17940: 33.5-34.2\%o). Thus the glacial nutrients at sites 17939 and 17940 may rather originate from terrigenous input than from the inflow.

During the middle to late Holocene and Stage 3 , low nutrients $\left(\sim 1.3-1.6 \%\right.$ and $\left.1.25 \% \circ \delta^{13} \mathrm{C}\right)$ prevailed in cores 17939 and 17940 . Here some shortterm excursions to higher nutrients may be linked to (warm) Dansgaard-Oeschger events $3 / 4$ and 8 (Fig. 3b and Fig. 4).
Southeast of Vietnam the $\delta^{13} \mathrm{C}$ values of core transect 17954-17956 (Fig. 3b) record past changes in the nutrient content of surface water across the (summer) monsoon-driven upwelling belt (Fig. 1; Wiesner et al., 1996). Over the last 230,000 years the $\delta^{13} \mathrm{C}$ values in the southernmost core 17956 were generally somewhat lower than further north (though less well resolved). Thus, the fertility was continuously lower in the north than in the south, where upwelling is strongest, such as today (Fig. 12A). Based on high $\delta^{13} \mathrm{C}$ values in all three cores (1.0$1.7 \%$ o) the nutrients were low during glacial and cold Stages 2, 3, 5.2, 5.4, 6, etc., which indicates weak upwelling intensity. In contrast, extremely low $\delta^{13} \mathrm{C}$ values of $0.4-0.6 \%$ o document an outstanding abundance of nutrients and strong upwelling and summer monsoon during Termination I and early Stage 1, more salient during Termination II and early Stage 5.5, and less prominent across the Stage 4-Stage 3 boundary (Fig. 3b and Fig. 13a).

In addition to monsoon-driven upwelling, the nutrients in the southwest SCS may also reflect maxima in the fluvial nutrient input, linked to increased monsoon rains and/or snow melt in the Himalayas (via the Mekong River) along with glacial terminations. In these periods the sea level was still low and the Mekong and Molengraaff rivers discharged near to the break of the Sunda shelf (Fig. 1). This concept is indeed supported by short-lasting and significant drops in SSS $(\Delta 1.5 \%$ ) found at site 17954 during Terminations I and II, during Stage 5.3 and, less clear, at Stage 5.1 (Fig. 10a). The high nutrient discharge of rivers from the glacial 'Sunda Land' is documented more directly by extremely low glacial and early deglacial planktonic and (organic-fluff-induced) benthic $\delta^{13} \mathrm{C}$ values at sites 17961 and 17964 (Fig. 3b,c), then lying proximal to the Sunda coastline.

Our results on monsoon-driven maxima in fluvial nutrient supply and summer upwelling during glacial Terminations I and II match the common expectations on the variability of the monsoon, expectations which are based on (1) the orbital periodicities in the intensity of the Indian monsoon, deduced from sediment records from the Arabian Sea (Clemens et al., 1991; Sirocko et al., 1996), and (2) on atmospheric climate modeling (Prell and Kutzbach, 1987; Kutzbach and Gallimore, 1988; Kutzbach et al., 1996). 

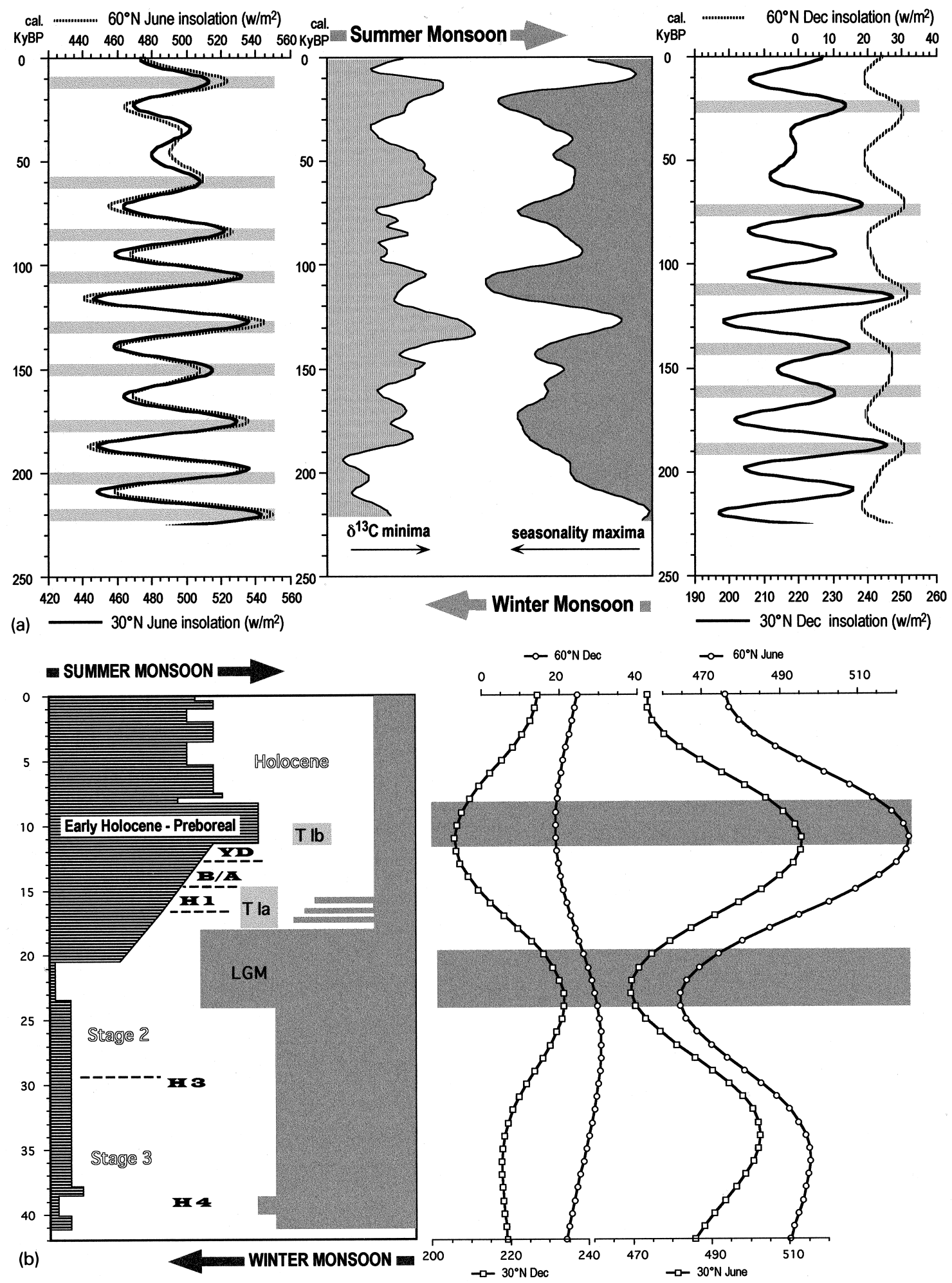


\subsection{Intra-Holocene variations and periodicities of the monsoon regime (premise 4)}

Prominent minima in winter and less, in summer PF-SST form striking signals of Holocene climatic change in the northern SCS about 8.2, 5.2-3.4, and 2-1 thousand calendar years ago, i.e. roughly every 3000 years (core 17940; Figs. 4 and 9). The minimum near 4500 calendar years ago is widely observed in Holocene sediments of West Pacific marginal seas (Oda and Takemoto, 1992; Jian et al., 1996; Wei et al., 1998), but not in the Kuroshio intensity (Sawada and Handa, 1998). The three cool events also match a reduction or disappearance of P. obliquiloculata, a deep-dwelling tropical warmwater species (Pflaumann and Jian, 1999). Based on both the spatial distribution pattern (Pflaumann and Jian, 1999) and $\delta^{13} \mathrm{C}$ composition of this species in modern sediments (Fig. 12B; Grothmann, 1996) P. obliquiloculata can trace the outlined nutrientrich inflow of upwelled water from the Luzon strait into the SCS during winter. Accordingly, the intraHolocene phases with an apparent PF-based temperature drop at site 17940 , which are paralleled by a disappearance of $P$. obliquiloculata, may just reflect a short-lasting southward deflection of the inflow from the east, probably linked to an increase in winter monsoon.

More far-reaching informations on the extent and frequency of short-term changes in the Holocene climate of South China were obtained from the ultrahigh-resolution paleosalinity record of core 17940 adjacent to the freshwater plume of the Pearl River (Figs. 1 and 11; 20-40 yr sample spacings). Here the match of the early Holocene coastline at $20 \mathrm{~m}$ water depth with the modern coastline of China (Hy- drographer of the Navy, 1985) precludes any lateral shift of the coastline along with $20 \mathrm{~m}$ of sea-level rise over the last 10,000 years (Fairbanks, 1989), different from the great glacial-to-interglacial changes. Thus, any Holocene SSS oscillations at site 17940 do not reflect a differential proximity to the Pearl River mouth but directly document the changes in monsoon rain in South China and the resulting freshwater discharge. This monsoon record is compared with the $\delta^{18} \mathrm{O}$ record of the ice-core GISP2 in Fig. 11 (Grootes and Stuiver, 1997).

Only after the marked early Holocene maximum in freshwater supply our SSS estimates reach gradually the general Holocene level of about $34.5 \%$. About 8300-8100 calendar years ago the SSS values arrive at a short-lasting double peak of $35.5 \%$ o and a subsequent, very short drop to $34.4 \%$, indicating a centennial oscillation from extreme aridity to extreme humidity. The SSS maxima are coeval with a major Holocene climatic cooling in Greenland (Fig. 11) and Antarctica (Ciais et al., 1992). Further upcore, the SSS record shows uniform variations of $\pm 0.7 \%$ oround the Holocene mean. Over the last 600 years the SSS values increased from a shortterm average near $34.5 \%$ o to the present average of $35.2 \%$. This increase may result from a recent reduction in monsoon rain since the early Little Ice Age, in parallel with a temperature rise in South China (and the Northern Hemisphere in general; Bradley and Jones, 1993). Based on the cyclic structure of the SSS record a fast return to a stronger freshwater input may be impending soon.

The fluctuations in SST and SSS over the last 10,000 years reflect submillennial periods of 775 years and 102/84 years in the East Asian monsoon regime, periodicities that each exceed the upper limit

Fig. 13. Summary schemes of variations in the East Asian monsoon over the last glacial cycle versus changes in solar insolation at $60^{\circ} \mathrm{N}$ and $30^{\circ} \mathrm{N}$ (Berger and Loutre, 1991). These latitudes represent the two end-member regions of the Asian winter and summer monsoon on land and on sea, characterized by totally different surface conditions. Arrows on top and bottom of the panel with the monsoon scheme point at increasing monsoon intensity. (a) Monsoon cycles over the last 220,000 years as inferred from a smoothed nutrient/upwelling record of planktonic $\delta^{13} \mathrm{C}$ minima $(G$. ruber) and the SST-seasonality record of planktonic foraminifera counts in core 17954 (data in Fig. 3b and Fig. 8). Peak glacial seasonality and winter monsoon largely correspond to minimum insolation during summer and a reduced insolation anomaly between land and sea. Vice versa, interglacial culminations in summer monsoon, such as about 10,000-11,000 yr $\mathrm{BP}$, parallel maximum insolation and maximum insolation anomalies between land and sea during summer (shaded bands). (b) Blow-up of monsoon variations over the last 40,000 years, based on variations in the differential input of siliciclastic sediments and SSS at site 17940 (Figs. 7 and 10a). Termination Ia and Ib ( $T I a$ and $T I b)$, the Younger Dryas (YD), Bølling-Allerød $(B / A)$, and Heinrich events 1 , 3 , and $4(H 1, H 3, H 4)$ are labeled. 
of red noise at $80 \%$ confidence level (Fig. 11) and lie far below the established range of Milankovitch orbital forcing. Similar periodicities also occur during Stages 2 and 3, but were not defined precisely because of insufficient time control in this section of core 17940 . The 775-year period amounts to approximately one quarter of the 3000-year cycle identified in the local SST record and to half of the salient 1500-year cyclicity, found in monsoon-controlled sediment records from the Arabian Sea (Sirocko et al., 1996), in North Atlantic sediments (Bond et al., 1997), and in particular, in the $\delta^{18} \mathrm{O}$ record of the GISP2 ice core from Greenland during Stages 2 and 3 (Grootes and Stuiver, 1997). Hence the 775-year periodicity may be a harmonics of the 1500 -year cycle. The 102/84-year periodicities may possibly reflect the Gleissberg cycle of solar activity, frequently described in ultrahigh-resolution records such as tree-ring $\Delta^{14} \mathrm{C}$ and the GISP2 ice core (Stuiver and Braziunas, 1993; Grootes and Stuiver, 1997).

However, compilations by Stocker and Mysack (1992) and Stocker (1996) show that a consistent theory on climatic cycles on decadal to centennial time scales still does not exist. Accordingly, the centennial periodicities in the Holocene variation of East Asian monsoon can be ascribed only tentatively to internal forcing mechanisms such as (1) harmonics of secondary Milankovitch cycles, driven via the global thermohaline circulation in the ocean, and (2) short-term changes in solar activity (L. Wang et al., unpubl. data).

\subsection{Linkages of monsoon to global climatic change: leads and lags}

The glacial-to-interglacial and millennial-scale changes in East Asian monsoon climate involved major changes in seasonal wind intensity, leading to the highly variable dust and moisture fluxes just discussed. These changes were basically controlled by variations in the thermal and pressure contrasts between (1) the (still-cool) tropical-subtropical IndoPacific, and (2) Tibet and other Central Asian land elevations serving as a strong heat source during summer because of their lapse-rate effects. Based on the GCM sensitivity tests and climate reconstructions of Prell and Kutzbach (1987), An et al. (1991), Kutzbach et al. (1996), and Morley and Heusser
(1997), the changing latitudinal anomalies of solar insolation due to orbital forcing (Fig. 13) played a crucial role in driving the past changes of monsoon. Especially, they were tied to the totally different surface conditions that mark the two end-member regions of Asian monsoon on sea at $30^{\circ}$ and on land at $60^{\circ} \mathrm{N}$ and lead to a differential absorption or reflection of the insolation budget.

Interactions among the three main spatial components of the Earth's climate system form another source of forcings: the Pleistocene to Holocene changes in low-latitude (East) Asian monsoon may have been primarily linked to southern or to northern high-latitude climate components, like circumAntarctic sea ice and temperatures or the build-up and melting of ice-sheets on the Northern Hemisphere continents. It is difficult to precisely disentangle the cause and effect relationships among these components and to detect the 'ultimate' source of forcing, because the three appear to be highly interactive (Ruddiman et al., 1989).

In our approach, we tried to constrain these problems by defining the precise timing, leads, and lags of past variations in summer and winter monsoon versus changes in the most prominent marine and ice-core records of global climate and sea-level change, especially focusing on a few major turning points of monsoon evolution during the last 230,000 and 40,000 calendar years. We used the GISP2 and VOSTOK $\delta^{18} \mathrm{O}$-temperature records from the Greenland and Antarctic ice sheets (Sowers and Bender, 1995; Grootes and Stuiver, 1997) as a measure for components of polar and global climate change. They were tied to the monsoon records via the benthic and planktonic $\delta^{18} \mathrm{O}$ records from the SCS by tuning and AMS- ${ }^{14} \mathrm{C}$-based age control (Fig. 4).

Test case one is the mid-Holocene decrease in SST and the inflow of West Pacific (?) subsurface water south of Hong Kong, starting about 52004400 calendar yr ago (core 17940; Figs. 4, 9 and 13b). This event paralleled precisely a short-lasting and marked weakening of North Atlantic Deep Water (NADW) ventilation off northwest Africa 48004600 yr ago (Maslin et al., 1996; Knaack, 1997) and hence suggests a joint atmospheric and/or thermohaline forcing of the ocean circulation.

Test case two concerns the major early Holocene fluctuations in SSS and monsoon at site 17940 off 
Hong Kong, lasting about 300 years near 8250 calendar yr BP. They coincided with the most prominent Holocene cooling in the GISP2 ice-core record (Fig. 11; Grootes and Stuiver, 1997), again with a short-lasting break-down in NADW ventilation (Maslin et al., 1996; Knaack, 1997), and with the start of the mid-Holocene dust discharge from Arabia into the Arabian Sea (Sirocko et al., 1993). However, any closer understanding of the actual linkages between these climate signals requires a more precise definition of the decadal- to centennial-scale leads and lags, which is limited by the precision of ${ }^{14} \mathrm{C}$ dates and their conversion into calendar years. We cannot fully fix yet, whether (1) the SSS maximum $8300 \mathrm{yr}$ ago has indeed matched the salient temperature minimum on Greenland, and (2) whether the subsequent extreme and short SSS minimum, i.e. the maximum in monsoon rain $8150 \mathrm{yr}$ ago has really succeeded the cool episode, which would imply a coincidence of cold and arid and warm and humid phases.

Test case three is the $<10-y r$ transition from the cold Younger Dryas to the warm Preboreal about 11,600 calendar years ago, documented in the Greenland ice cores (Dansgaard et al., 1989; Grootes et al., 1993; Fig. 4). Off Hong Kong this climatic turning point went along with a massive rise in monsoon precipitation over less than $50-100 \mathrm{yr}$, as reflected by the decrease in salinity and onset of fluvial mud deposition in the ultrahigh-resolution sediment records of cores 17940 and -39 (Figs. 6 and 10). Moreover, a sudden coeval rise in winter and annual-mean SST occurred in all parts of the SCS (Fig. 9), also in the southeast (Thunell and Miao, 1996). The subsequent Preboreal to early Holocene culmination in the East Asian monsoon precisely paralleled a comparable maximum of the Indian summer monsoon found in Arabian Sea sediments (Sirocko et al., 1993), when solar insolation and summer temperatures on Greenland (Koerner and Fisher, 1990) reached a maximum.

Test case four suffers from still-controversial dating precision. The grain-size- and SSS-based shortterm monsoon oscillations, which were identified at site 17940 during Stage 3, are considered as coeval with Heinrich events 4 and 3 (Figs. 4, 6, 9 and 10). However, the ${ }^{14} \mathrm{C}$ age of 35,500 years $\mathrm{BP}$, which was measured on the $\delta^{18} \mathrm{O}$ maximum assigned to Heinrich event 4 , implies an abnormally high oceanic
${ }^{14} \mathrm{C}$-reservoir age of SCS-surface water, reaching 1.5 $\mathrm{ka}$ in comparison to a ${ }^{14} \mathrm{C}$ age of $34 \mathrm{ka}$ measured in the Norwegian Sea (Adkins and Boyle, 1997; Völker et al., 1998). If this assumption is correct, the monsoon oscillations near Heinrich events 4 and 3 may indeed contribute to a better general understanding of short-term climatic change. Together with test cases 2 and 3 for the Holocene and YD and a new record of Stage-3 variations of the Indian monsoon (Schulz et al., 1998), they suggest that any short-term changes in the Asian monsoon system were intimately tied to high-latitude climate forcing such as major iceberg surges in the North Atlantic (Broecker et al., 1990; Bond and Lotti, 1995). We guess that this may have occurred on decadal to 100-year time spans mainly via atmospheric climatic forcing. No leads and lags were identified so far.

In contrast, significant leads and lags mark our final test case, the onset of glacial Termination IA, where the ultrahigh-resolution sediment records of monsoon humidity and the planktonic and benthic $\delta^{18} \mathrm{O}$ signals of global climatic change indicate considerable age deviations (cores 17940 and -39 in Figs. 3, 4 and 6; close-up in Fig. 7). At site 17940 the clay fraction, a rough tracer of fluvial runoff, started to rise from $<50 \%$ up to an almost Holocene level of $60-70 \%$ as early as $17.0-14.7$ thousand ${ }^{14} \mathrm{C}$ years ago, i.e. right after the Milankovitch solar insolation minimum almost $18,000{ }^{14} \mathrm{C}$ years ago equal to 21,000 calendar years. The rise in clay supply preceded the strongly fluctuating onset of postglacial $\delta^{18} \mathrm{O}$ signals of sea-level rise by $3000-4000$ years, which slowly started at 14,000 and more pronounced after $13,200{ }^{14} \mathrm{C}$ years $\mathrm{BP}$, near the base of the Bølling. At this time the rise in fluvial clay input had finally reached the more distal site 17939. By contrast, the dust modal grain sizes show a first, abrupt postglacial drop from 25 to $10 \mu \mathrm{m}$ near $15,000{ }^{14} \mathrm{C}$ years $\mathrm{BP}$ and a subsequent, more gradual decrease until $13,400{ }^{14} \mathrm{C}$ years BP $(885-810 \mathrm{~cm}$ c.d. in core 17940; Figs. 6 and 7).

The outlined phase relationships among different paleoclimatic signals near the start of glacial Termination IA lead us to the following conclusions (Fig. 13b). (1) The initial rapid increase in clay supply occurred independent of the postglacial sea-level rise but was solely controlled by enhanced fluvial sediment supply from South China. (2) This early 
signal of intensified monsoon rains during summer paralleled the start of Antarctic ice melt (Sowers and Bender, 1995) and thus was linked to climate components of southern high latitudes. (3) Vice versa, the delayed decrease in loess-grain sizes and strength of winter-monsoon winds went along with a major melt of northern high-latitude glaciation directly prior to the Bølling/Dansgaard-Oeschger event 1 (GISP2 record in Fig. 4). In harmony with these conclusions, the maximum in winter-monsoon winds slightly lagged the minimum in northern insolation, whereas the peak in monsoon precipitation during summer was in phase with maximum northern insolation (Fig. 13b). This relation likewise applies to the East Asian and Indian monsoon systems.

In most cores from the SCS the record on monsoon variations is tied to global climatic change via well defined events of planktonic $\delta^{18} \mathrm{O}$ stratigraphy (Fig. 4). However, our ${ }^{14} \mathrm{C}$ datings in core 17940 also suggest millennial-scale phase lags of $\delta^{18} \mathrm{O}$ events in the SCS vs. $\delta^{18} \mathrm{O}$ events measured elsewhere. Termination IA only started near $14,000{ }^{14} \mathrm{C}$ years $\mathrm{BP}$ in both the planktonic and benthic $\delta^{18} \mathrm{O}$ records (840-845 cm c.d.; Fig. 3c and Fig. 4; Table 3). This age lags 600-1000 years behind the ages found in dozens of benthic and planktonic $\delta^{18} \mathrm{O}$ records from the Atlantic (Winn et al., 1991; Sarnthein et al., 1995). The lag represents the time span needed for an ocean-wide spreading of the early deglacial $\delta^{18} \mathrm{O}$ signal and confirms previous estimates (800-1000 years; Duplessy et al., 1991). However, the actual lag may be larger in view of the high ${ }^{14} \mathrm{C}$-reservoir ages which exceed 1500 years in the SCS during Heinrich event 4 and are difficult to assess at Heinrich event 1 (Fig. 5).

\section{Conclusions}

Past changes in the East Asian monsoon were deduced from ten well dated sediment records with millennial to bidecadal time resolution from core transects across the northern, western, and southern margins of the subtropical and tropical South China Sea (SCS). Based on a broad multiproxy-data set we drew the following conclusions on climate and ocean variability over the last 220,000 years and in particular, the last 40,000 years.
(1) Two extremes of monsoon circulation alternated with the glacial-to-interglacial cycles driven by minima and maxima of Northern Hemisphere solar insolation (Fig. 13): a strongly intensified winter monsoon and weakened summer monsoon were typical of glacial periods. They involved a strongly reduced monsoon precipitation during summer, i.e. continental aridity in subtropical South China, a noticeable discharge of loess dust, markedly lowered SST during winter, and an enhanced seasonality all over the SCS. In contrast, the Holocene and other interglacial regimes were characterized by a strengthened summer-monsoon circulation and weak winter-monsoon winds. They led to extreme continental wetness in South China, to high winter SST and a low seasonality in the whole SCS, and to high upwelling productivity southeast of Vietnam, possibly also to an increased frequency of typhoon storms.

(2) An excess in siliciclastic clay and extended periods of reduced SSS indicate an ongoing fluvial sediment supply along the southern margin of the SCS during Stages 2-4. Based on these findings the emerged Sunda shelf was humid and drained by Amazone-style tropical rivers, a region which served as glacial refuge for tropical forests, in harmony with the marine pollen record (X. Sun, pers. commun., 1997).

(3) Glacial-to-interglacial sea-level changes had a significant impact on the paleoceanography of the SCS via the closure and opening of the strait of Borneo at a threshold water depth of about $40 \mathrm{~m}$. During interglacial periods with high sea level the lateral advection of warm surface water from the tropical West Pacific led to a significant general rise in annual mean SST (based on $\mathrm{U}_{37}^{\mathrm{K}}$ records). Vice versa, the glacial closure of the Borneo strait led to an intensified inflow of cool and nutrient-rich surface water from the northeast, which was upwelled near the northern tip of Luzon during winter. It is traced in SST, SSS, and $\delta^{13} \mathrm{C}$ records of planktonic foraminifera, moreover, by the frequency of $P$. obliquiloculata.

(4) The glacial separation of the SCS in the southwest involved a strengthened estuarine circulation mode. Together with the massive discharge of tropical rivers this mode led to extreme oxygen depletion near $1500 \mathrm{~m}$ water depth along the southern margin 
of the sea and to epibenthic $\delta^{13} \mathrm{C}$ values as low as -0.5 to $<-1.5 \%$.

(5) SST, SSS, and siliciclastic grain-size records from the northern SCS contain a history of significant centennial to millennial-scale events. Cold spells occurred roughly every 3000 years during the Holocene. The Younger Dryas did not induce a cooling but an arid episode. Heinrich event 4 probably corresponded to an arid and cool phase in South China. In the southern and western SCS short-lasting extreme SSS minima reflect major freshwater floodings by summer-monsoon rain near Termination II and IA and in late Stage 3, presumably linked to the warm Dansgaard-Oeschger events 8 and 4 to 3 .

(6) The high-frequency oscillations of Holocene monsoon wetness in South China center at periodicities of 775 and 102/84 years. The 775-year cycle may form a subharmonics of the 1500-year cycle, recently described in ice-core and marine-sediment records and assigned to changes in oceanic thermohaline circulation. The 102/84 cyclicity may correspond to the Gleissberg period of solar activity.

(7) During the last 600 years, approximately since the early Little Ice Age, the SSS values have increased southeast of Hong Kong. They imply a recent drop in monsoon precipitation over South China, coeval with growing temperature amplitudes recorded in the ice-core GISP2 from Greenland, and possibly, an impending fast return to greater wetness.

(8) Both short-lasting and long-term variations in the East Asian monsoon were coeval with variations in the Indian monsoon regime, based on published evidence from Arabian Sea sediments, which involves a joint (atmospheric?) forcing.

(9) Phase relationships among various paleoclimatic proxy records off Hong Kong during the onset of glacial Termination IA suggest that the summermonsoon-driven fluvial runoff and sediment supply intensified right after the LGM insolation minimum, parallel to the early start of Antarctic ice melt and about $3500 \mathrm{yr}$ prior to the $\delta^{18} \mathrm{O}$ signal of postglacial sea-level rise. Vice versa, the grain-size record of dust suggests a delayed but abrupt decrease in the strength of winter-monsoon winds only about 15,000 calendar years ago, along with the melt of northern glacial ice sheets.

(10) Based on a precise age tuning of Heinrich- 4 and other climate oscillations the local oceanic
${ }^{14} \mathrm{C}$-reservoir effect may have reached 1500 years during times of low sea level, when the emerged Sunda shelf barred the advection of young surface water from the south and the enhanced estuarine circulation in the SCS led to an upwelling of old Pacific intermediate and deep water. Here ${ }^{14} \mathrm{C}$ datings may rather serve as sensitive tracers of past circulation changes than for estimating the precise age of climate oscillations.

\section{Acknowledgements}

We gratefully acknowledge the German Ministry for Education and Research (BMBF) and the Deutsche Forschungsgemeinschaft in Bonn (DFG) for their generous support of the Sonne Cruise 95 to the South China Sea and the subsequent scientific evaluation. We sincerely thank A. Berger, A. Grothmann, W. Kuhnt, H. Lin, T. Stocker, X. Sun, and $\mathrm{M}$. Weinelt for supplementary data and valuable discussions on various aspects of changes in monsoon climate, moreover, F. Sirocko and P. Wang for thorough reviews of the manuscript. We also thank M. Schulz for providing the software on the smooth-spline technique and important comments. We acknowledge M. Nadeau and M. Schleicher who provided great expertise and care in measuring AMS- ${ }^{14} \mathrm{C}$ ages. Thanks also go to K. Kissling, $\mathrm{H}$. Aeffner, W. Rehder, and numerous students for laboratory assistance, and captain Bruns and the crew of $\mathrm{R} / \mathrm{V}$ Sonne and especially, to Norbert Mühlhan for technical assistance in retrieving undisturbed, long sediment cores. One of the authors (LW) thanks the Graduate School of Environmental Earth Sciences of Hokkaido University, where parts of the manuscript were finished. C.P. thanks CIRIT, Generalitat de Catalunya, for a grant.

\section{References}

Adkins, J.F., Boyle, E.A., 1997. Changing atmospheric $\Delta{ }^{14}$ C and the record of deep water paleoventilation ages. Paleoceanography $12,337-344$.

Alley, R.B., Meese, D.A., Shuman, C.A., Gow, A.J., Taylor, K.L., Grootes, P.M., White, J.W.C., Ram, M., Waddington, E.D., Mayewski, P.A., Zielinski, G.A., 1993. Abrupt increase in Greenland snow accumulation at the end of the Younger 
Dryas event. Nature 362, 527-529.

An, Z., Kukla, G., Porter, S.C., Xiao, X., 1991. Paleomonsoons of China over the last 130,000 years - paleomonsoon variation. Sci. China (B) 34, 1016-1024.

Banerjee, S.K., 1995. Chasing the paleomonsoon over China: its magnetic record. GSA Today 5, 93-97.

Bard, E., Hamelin, B., Fairbanks, R.G., Zindler, A., 1990a. Calibration of the ${ }^{14} \mathrm{C}$ timescale over the past 30,000 years using mass spectrometric U-Th ages from Barbados corals. Nature 345, 405-410.

Bard, E., Hamelin, B., Fairbanks, R.G., 1990b. U-Th ages obtained by mass-spectrometry in corals from Barbados: sea level during the past 130,000 years. Nature 346, 456-458.

Bard, E., Arnold, M., Hamelin, B., Tismerat-Iaborde, N., 1998. Comparison of U/Th and $\mathrm{C} 14$ ages measured on corals: an update based on new samples from Pacific islands. Radiocarbon 40 (in press).

Berger, A., Loutre, M.F., 1991. Insolation values for the climate of the last 10 million of years. Quat. Sci. Rev. 10, 297-317.

Blunier, T., Chappellaz, J., Schwander, J., Stauffer, B., Raynaud, D., 1995. Variations in atmospheric methane concentration during the Holocene epoch. Nature 374, 46-49.

Bond, G., Lotti, R., 1995. Iceberg discharges into the North Atlantic on millennial time scales during the last glaciation. Science 267, 1005-1010.

Bond, G., Heinrich, H., Broecker, W., Labeyrie, L., McManus, J., Andrews, J., Huon, S., Jantschik, R., Clasen, S., Simet, C., Tedesco, K., Klas, M., Bonani, G., Ivy, S., 1992. Evidence for massive discharges of icebergs into the North Atlantic ocean during the last glacial period. Nature 360, 245-249.

Bond, G., Showers, W., Cheseby, M., Lotti, R., Almasi, P., de Menocal, P., Priore, P., Cullen, H., Hajdas, I., Bonani, G., 1997. A pervasive millennial-scale cycle in North Atlantic Holocene and glacial climates. Science 278, 1257-1266.

Bradley, R.S., Jones, P.D., 1993. 'Little Ice Age' summer temperature variations: their nature and relevance to recent global trends. Holocene 3, 367-376.

Broecker, W.S., Peng, F.H., 1982. Tracers in the sea. Eldigio Press, 679 pp.

Broecker, W.S., Andree, M., Bonani, G., Wolfli, W., Mix, A., Oeschger, H., 1988. Comparison between radiocarbon ages obtained on coexisting planktonic foraminifera. Paleoceanography 3, 647-657.

Broecker, W.S., Bond, G., Klas, M., 1990. A salt oscillator in the glacial Atlantic? 1. The concept. Paleoceanography 5, 469477.

Chappell, J., Omura, A., Esat, T., McCulloch, M., Pandolfi, J., Ota, T., Pilans, B., 1996. Reconciliation of late Quaternary sea levels derived from coral terraces at Huon Peninsula with deep-sea oxygen isotope records. Earth Planet. Sci. Lett. 141, 227-236.

Ciais, P., Jouzel, J., Lorius, C., Barkov, N.I., Lipenkov, V., Nikolaiev, V., 1992. Evidence for an early Holocene climatic optimum in the Antarctic deep ice-core record. Clim. Dyn. 6, 169-177.

Clemens, S., Prell, W., Murray, D., Shimmield, G., Weedon,
G., 1991. Forcing mechanisms of the Indian Ocean monsoon. Nature 353, 720-725.

CLIMAP project members, 1981. Seasonal reconstructions of the Earth's surface at the Last Glacial Maximum. Geol. Soc. Am. Map and Chart Ser. MC-36.

Cortijo, E., Yiou, P., Labeyrie, L., Cremer, M., 1995. Sedimentary record of rapid climatic variability in the North Atlantic Ocean during the last glacial cycle. Paleoceanography 10, 911-926.

Dansgaard, W., White, J.W.C., Johnsen, S., 1989. The abrupt termination of the Younger Dryas climate event. Nature 339, 532-533.

Duplessy, J.C., Bé, A.W.H., Blanc, P.L., 1981. Oxygen and carbon isotopic composition and biogeographic distribution of planktonic foraminifera in the Indian Ocean. Palaeogeogr., Palaeoclimatol., Palaeoecol. 33, 9-46.

Duplessy, J.-C., Arnold, M., Bard, E., Juillet-Leclerc, A., Kallel, N., Labeyrie, L., 1989. AMS ${ }^{14} \mathrm{C}$ study of transient events and of the ventilation rate of the Pacific intermediate water during the last deglaciation. Radiocarbon 31, 493-502.

Duplessy, J.C., Bard, E., Arnold, M., Shackleton, N.J., Duprat, J., Labeyrie, L., 1991. How fast did the ocean-atmosphere system run during the last deglaciation? Earth Planet. Sci. Lett. 103, 27-40.

Evans, C.D.R., Brett, C.P., James, J.W.C., Holmes, R., 1995. Shallow seismic reflection profiles from the waters of East and Southeast Asia: an interpretation manual and atlas. British Geological Survey, Tech. Rep. WC/94/60, Overseas Geology Series, pp. 66-67.

Fairbanks, R.G., 1989. A 17,000-year glacio-eustatic sea level record: influence of glacial melting rates on the Younger Dryas event and deep-ocean circulation. Nature 342, 637-642.

Fairbanks, R.G., Wiebe, P.H., Bé, A.W.H., 1980. Vertical distribution and isotopic composition of living planktonic foraminifera in the Western North Atlantic. Science 207, 6163.

Fairbanks, R.G., Sverdlove, M., Free, R., Wiebe, P.H., Bé, A.W.H., 1982. Vertical distribution and isotopic fractionation of living planktonic foraminifera from the Panama Basin. Nature 298, 841-844.

Ganssen, G., Sarnthein, M., 1983. Stable isotope composition of foraminifers: the surface and bottom water record of coastal upwelling. In: Suess, E., Thiede, J. (Eds.), Coastal Upwelling: Its Sediment Record, Part A: Responses of the Sedimentary Regime to Present Coastal Upwelling. Plenum Press, New York, pp. 99-121.

Gordon, A.L., 1986. Interocean exchange of thermocline water. J. Geophys. Res. 91, 5037-5046.

Grootes, P.M., Stuiver, M., 1997. ${ }^{18} \mathrm{O} /{ }^{16} \mathrm{O}$ variability in Greenland snow and ice with $10^{-3}$ to $10^{-5} \mathrm{yr}$ time resolution. J. Geophys. Res. 102 (C12), 26455-26470.

Grootes, P.M., Stuiver, M., White, J.W.C., Johnsen, S., Jouzel, J., 1993. Comparison of oxygen isotope records from the GISP2 and GRIP Greenland ice cores. Nature 366, 552-554.

Grothmann, A., 1996. Rezente Verbreitungsmuster vulkanischer, terrigener und biogener Komponenten und stabiler Kohlen- 
stoff- und Sauerstoff-Isotope in Sedimenten der Südchina-See. M.Sc. Thesis, Kiel University.

Hemleben, C., Spindler, M., Anderson, O.R., 1989. Modern Planktonic Foraminifera. Springer, New York, 363 pp.

Hughen, K.A., Overpeck, J.T., Lehman, S.J., Kashgarian, M., Southon, J., Peterson, L.C., Alley, R., Sigman, D.M., 1998. Deglacial changes in the ocean circulation from an extended radiocarbon calibration. Nature 391, 65-68.

Hydrographer of the Navy and under the Superintendence of Rear Admiral R.O. Morris, 1985. Taiwan Strait, (C) Crown Copyright, Taunton.

Japan Hydrographic Association, 1978. Marine Environmental Atlas: Northwestern Pacific II, Japan Oceanographic Data Center, Tokyo.

Jian, Z., Li, B., Pflaumann, U., Wang, P., 1996. Late Holocene cooling event in the western Pacific. Sci. China (D) 39, 552560 .

Kennett, J.P., Ingram, B.C., 1995. A 20,000-year record of ocean circulation and climate change from the Santa Barbara basin. Nature 377, 510-514.

Kienast, M., 1996. Geschichte des Fluvialeintrags vom SundaSchelf: Abbild in hemipelagischen Sedimenten aus dem Südchinesischen Meer. M.Sc. Thesis, Kiel University, 53 pp.

Kirch, A., 1997. Zur Paläoozeanographie westlich von Luzon (Philippinen). M.Sc. Thesis, Kiel University, 28 pp.

Knaack, J.J., 1997. A new transfer function to reconstruct paleoproductivity from marine diatom assemblages (in German). Ber.-Rep., Geol.-Palaeontol. Inst. Univ. Kiel 83, 1-125.

Koerner, R.M., Fisher, D.A., 1990. A record of Holocene summer climate from a Canadian high-Arctic ice core. Nature 343, 630-631.

Koopmann, B., 1981. Saharan dust deposition in the subtropical Atlantic during the last 25,000 years (in German) . 'Meteor' Forschungsergeb. C 5, 23-54.

Kotilainen, A.T., Shackleton, N.J., 1995. Rapid climate variability in the North Pacific Ocean during the past 95,000 years. Nature 377, 323-326.

Kromer, B., Becker, B., 1993. German oak and pine ${ }^{14} \mathrm{C}$ calibration, 7200 BC-9400 BC. Radiocarbon 35, 125-136.

Kudrass, H.R., Erlenkeuser, H., Vollbrecht, R., Weiss, W., 1991. Global nature of the Younger Dryas cooling event inferred from oxygen isotope data from Sulu Sea cores. Nature 349, 406-409.

Kukla, G., Heller, F., Ming X, L.-, Chun, X.-T., Liu, T.-S., An, Z.-S., 1988. Pleistocene climates in China dated by magnetic susceptibility. Geology 16, 811-814.

Kutzbach, J.E., Gallimore, R.G., 1988. Sensitivity of a coupled atmosphere/mixed layer ocean model to changes in orbital forcing at 9,000 years B.P. J. Geophys. Res. 93 (D1), 803821.

Kutzbach, J., Bonan, G., Foley, J., Harrison, S.P., 1996. Vegetation and soil feedbacks on the response of the African monsoon to Orbital forcing in the early to middle Holocene. Nature 384, 623-626.

Labeyrie, L.D., Duplessy, J.-C., Blanc, P.L., 1987. Variations in mode of formation and temperature of oceanic deep waters over the past 125,000 years. Nature $327,477-482$.
Laj, C., Mazaud, A., Duplessy, J.-C., 1996. Geomagnetic intensity and ${ }^{14} \mathrm{C}$ abundance in the atmosphere and ocean during the past 50 ka. Geophys. Res. Lett. 23, 2045-2048.

Levitus, S., Boyer, T.P., 1994. World Ocean Atlas 1994, Vol. 4. Temperature. NOAA, U.S. Dep. Commerce, Washington, DC, 117 pp.

Liu, T., Ding, Z., 1993. Stepwise coupling of monsoon circulations to global ice volume variations during the late Cenozoic. Global Planet. Sci. 7, 119-130.

Martinson, D.G., Pisias, W.G., Hays, J.D., Imbrie, J., Moore Jr., T.C., Shackleton, N.J., 1987. Age and dating and the orbital theory of the ice age: development of a high resolution 0300,000 year chronostratigraphy. Quat. Res. 27, 1-29.

Maslin, M., Sarnthein, M., Knaack, J.J., 1996. Subtropical eastern Atlantic climate during the Eemian. Naturwissenschaften 83, 122-126.

Metzger, E.J., Hurlbert, H.E., 1996. Coupled dynamics of the South China Sea, the Sulu Sea, and the Pacific Ocean. J. Geophys. Res. 101, 12331-12352.

Miao, Q., Thunell, R.C., 1994. Glacial-Holocene carbonate dissolution and sea-surface temperatures in the South China and Sulu Seas. Paleoceanography 9, 269-290.

Molengraaff, G.A.F., 1921. Modern deep-sea research in the East Indian Archipelago. Geogr. J. 57, 95-121.

Morley, J.J., Heusser, L.E., 1997. Role of orbital forcing in east Asian monsoon climates during the last 350 kyr: evidence from terrestrial and marine proxies from core RC14-99. Paleoceanography 12, 483-493.

Mulitza, S., Niebler, H.S., Duerkoop, A., Wefer, G., 1997. Planktonic foraminifera as recorders of past surface water stratification. Geology 25, 335-338.

Müller, P.J., Cepek, M., Ruhland, G., Schneider, R., 1997. Alkenone and coccolithophorid species changes in late Quaternary sediments from the Walvis Ridge: implications for the alkenone paleotemperature method. Palaeogeogr., Palaeoclimatol., Palaeoecol. 135, 71-96.

Müller, P.J., Kirst, G., Ruhland, G., von Storch, I., Rosell-Melé, A., 1998. Calibration of the alkenone paleotemperature index $\mathrm{Uk}^{\prime} 37$ based on core-tops from the eastern South Atlantic and global ocean $\left(60^{\circ} \mathrm{N}-60^{\circ} \mathrm{S}\right)$. Geochim. Cosmochim. Acta (in press).

Nadeau, M.-J., Schleicher, M., Grootes, P.M., Erlenkeuser, E., Gottdang, A., Mous, D.J.W., Sarnthein, M., Willkomm, H., 1997. The Leibniz-Labor AMS facility at the ChristianAlbrechts-University, Kiel, Germany. Nucl. Instrum. Methods Phys. Res. B 123, 22-30.

Oda, M., Takemoto, A., 1992. Planktonic foraminifera and paleoceanography in the domain of Kuroshio current around Japan during the last 20,000 years (in Japanese). Quat. Res. 31, 341357.

Paillard, D., Labeyrie, L., Yiou, P., 1996. Macintosh program performs time-series analysis. EOS 77, 379.

Parkin, D.W., Shackleton, N.J., 1973. Trade Wind and temperature correlations down a deep-sea core off the Saharan Coast. Nature 245, 455-457.

Pearson, G.W., Becker, B., Qua, F., 1993. High-precision ${ }^{14} \mathrm{C}$ measurement of German and Irish oaks to show the natural 
${ }^{14} \mathrm{C}$ variations from 7890 to 5000 BC. Radiocarbon 35, 93104.

Pelejero, C., Grimalt, J.O., 1997. The correlation between the $\mathrm{U}_{37}^{\mathrm{K}}$ index and sea surface temperature in the warm boundary: the South China Sea. Geochim. Cosmochim. Acta 61, 47894797.

Pelejero, C., Grimalt, J.O., Sarnthein, M., Wang, L., Flores, J.-A., 1999. Molecular biomarker record of sea surface temperature and climatic change in the South China Sea during the last 130,000 years. Mar. Geol. 156, 109-121.

Pflaumann, U., Jian, Z., 1999. Modern distribution patterns of planktonic foraminifera in the South China Sea and West Pacific: a new transfer technique to estimate regional sea-surface temperature. Mar. Geol. 156, 41-83.

Porter, S.C., An, Z., 1995. Correlation between climate events in the North Atlantic and China during the last glaciation. Nature 375, 305-308.

Prell, W.L., Kutzbach, J.E., 1987. Monsoon variability over the past 150,000 years. J. Geophys. Res. 92, 8411-8425.

Prell, W.L., Imbrie, J., Martinson, D.G., Morley, J.J., Pisias, N.G., Shackleton, N.J., Streeter, H.F., 1986. Graphic correlation of oxygen isotope stratigraphy application to the Late Quaternary. Paleoceanography 1, 137-162.

Prentice, I.C., Sarnthein, M., 1993. Self-regulatory processes in the biosphere in the face of climate change. In: Eddy, J.A., Oeschger, H. (Eds.), Global Changes in the Perspective of the past. (Dahlem Konferenzen), Wiley, New York, pp. 29-38.

Pye, K., Zhou, L., 1989. Late Pleistocene and Holocene aeolian dust deposition in north China and the northwest Pacific Ocean. Palaeogeogr., Palaeoclimatol., Palaeoecol. 73, 11-23.

Reinsch, C.H., 1967. Smoothing by spline functions. Numer. Math. 10, 177-183.

Rosenthal, Y., Boyle, E.A., Labeyrie, L., 1997. Last glacial maximum paleochemistry and deepwater circulation in the Southern Ocean: evidence from foraminiferal cadmium. Paleoceanography 12, 787-796.

Rostek, F., Ruhland, G., Bassinot, F., Mueller, P.J., Labeyrie, L.D., Lancelot, Y., Bard, E., 1993. Reconstructing sea surface temperature and salinity using $\delta^{18} \mathrm{O}$ and alkenone records. Nature 364, 319-321.

Ruddiman, W.F., Sarnthein, M., Backman, J., et al., 1989. PlioPleistocene evolution of climate in Africa and the equatorial Atlantic: overview of Leg 108 results. In: Ruddiman, W.F., Sarnthein, M., et al. (Eds.), Proceedings of Ocean Drilling Project Leg 108, Vol. B. U.S. Government Printing Office, Washington, DC, pp. 463-484.

Sarnthein, M., Tiedemann, R., 1990. Younger Dryas-style cooling events at glacial terminations I-VI: associated benthic $\delta^{13} \mathrm{C}$ anomalies at ODP Site 658 constrain meltwater hypothesis. Paleoceanography 6, 1041-1055.

Sarnthein, M., Winn, K., 1990. Reconstruction of low and midlatitude export productivity, 30,000 y B.P. to Present: implications for global carbon and nutrient reservoirs. In: Schlesinger, M. (Ed.), Climate and Ocean Interaction. Proc. NATO ARW, Oxford, Sep. 1988, pp. 319-342.

Sarnthein, M., Tetzlaff, G., Koopmann, B., Wolter, K., Pflaumann, U., 1981. Glacial and interglacial wind regimes over the eastern subtropical Atlantic and NW Africa. Nature 293, 193-196.

Sarnthein, M., Winn, K., Duplessy, J.-C., Fontugne, M.R., 1988. Global variations in surface ocean productivity in low and mid latitudes: influence on $\mathrm{CO}_{2}$ reservoirs of the deep ocean and atmosphere during the last 21,000 years. Paleoceanography 3, 361-399.

Sarnthein, M., Pflaumann, U., Wang, P.X., Wong, H.K. (Eds.), 1994a. Preliminary Report on SONNE-95 Cruise 'Monitor Monsoon' to the South China Sea. Ber-Rep., Geol.-Palaeontol. Inst. Univ. Kiel 48, 225 pp.

Sarnthein, M., Winn, K., Jung, S.J.A., Duplessy, J.-C., Labeyrie, L., Erlenkeuser, H., Ganssen, G., 1994b. Changes in East Atlantic deepwater circulation over the last 30,000 years: eight time slice reconstructions. Paleoceanography 9, 209-267.

Sarnthein, M., Jansen, E., Weinelt, M., Arnold, M., Duplessy, J.C., Erlenkeuser, H., Flatöy, A., Johannessen, G., Johannessen, T., Jung, S., Koc, N., Labeyrie, L., Pflaumann, U., Schulz, H., 1995. Variations in Atlantic surface ocean paleoceanography, $50^{\circ}-85^{\circ} \mathrm{N}$ : a time-slice record of the last 30,000 years. Paleoceanography 10, 1063-1094.

Sawada, K., Handa, N., 1998. Variability of the Kuroshio ocean current over the past 25,000 years. Nature 392, 592-595.

Schleicher, M., Grootes, P.M., Nadeau, M.J., Schoon, A., 1998. ${ }^{14} \mathrm{C}$ backgrounds and their components at the Leibniz AMS facility. Radiocarbon 40 (in press).

Schulz, H., von Rad, U., Erlenkeuser, H., 1998. Correlation between Arabian Sea and Greenland climate oscillations of the past 110,000 years. Nature 393, 54-57.

Seidov, D., Sarnthein, M., Stattegger, K., Prien, R., Weinelt, M., 1996. North Atlantic ocean circulation during the last glacial maximum and subsequent meltwater event: a numerical model. J. Geophys. Res. 101, 16305-16332.

Shackleton, N.J., Duplessy, J.C., Arnold, M., Maurice, P., Hall, N.A., Cartlidge, J., 1988. Radiocarbon age of East glacial Pacific deep water. Nature 335, 708-711.

Shi, Y., Kong, Z., Wang, S., Tang, L., Yao, T., Zhao, X., Zhang, P., Shi, S., 1993. Mid-Holocene climates and environments in China. Global Planet. Change 7, 219-233.

Sirocko, F., Sarnthein, M., Erlenkeuser, H., Lange, H., Arnold, M., Duplessy, J.C., 1993. Century-scale events in monsoonal climate over the past 24,000 years. Nature 364, 322-324.

Sirocko, F., Garbe-Schoenberg, D., McIntyre, A., Molfino, B., 1996. Teleconnection between the subtropical Monsoon and high-latitude climate during the last deglaciation. Science 272, 526-529.

Sowers, T., Bender, M., 1995. Climate records covering the last deglaciation. Science, 210-214.

Stattegger, K., Kuhnt, W., Wong, H.K., et al., 1997. Cruise Report SONNE 115 SUNDAFLUT. Sequenzstratigraphie, spätpleistozän-holozäne Meeresspiegelschwankungen und hochauflösende Rekonstruktion der postpleistozänen Transgression am Sunda Schelf. Ber.-Rep., Geol.-Palaeontol. Inst. Univ. Kiel 86, 1-211.

Stein, R., 1985. Rapid grain-size analyses of clay and silt fraction by Sedigraph 5100D: comparison with Coulter Counter and Atterberg methods. J. Sediment Petrol. 55, 590-615. 
Stocker, T., 1996. An overview of century time-scale variability in the climate system: observations and models. In: Anderson, D.L.T., Willebrand, J. (Eds.), Decadal Climate Variability, Dynamics and Predictability. NATO ASI Series I, 44, Springer, Berlin, pp. 380-406.

Stocker, T., Mysack, A., 1992. Climatic fluctuations on the century time scale: A review of high-resolution proxy data and possible mechanisms. Climatic Change 20, 227-250.

Stuiver, M., Becker, B., 1993. High-precision decadal calibration of the radiocarbon time scale, AD 1950-6000 BC. Radiocarbon $35,35-65$.

Stuiver, M., Braziunas, T.F., 1993. Modelling atmospheric ${ }^{14} \mathrm{C}$ influences and ${ }^{14} \mathrm{C}$ ages of marine samples to $10,000 \mathrm{BC}$. Radiocarbon 35, 137-189.

Stuiver, M., Pearson, G.W., 1993. High precision calibration of the radiocarbon time scale AD 1950-500 BC and 2500-6000 BC. Radiocarbon 35, 1-24.

Stuiver, M., Grootes, P.M., Braziunas, T.F., 1995. The GISP2 $\delta^{18} \mathrm{O}$ climate record of the past 16,500 years and the role of the Sun, ocean, and volcanoes. Quat. Res. 44, 341-354.

Sun, X., Li, X., 1999. Pollen records of the last 37 ka in deep-sea core 17940 from the northern slope of the South China Sea. Mar. Geol. 156, 227-244.

Tchernia, P., 1980. Descriptive Regional Oceanography. Marine Series 3, Pergamon Press, Oxford, 253 pp.

Thompson, P.R., 1981. Planktonic foraminifera in the Western North Pacific during the past 150,000 years: comparison of modern and fossil assemblages. Palaeogeogr., Palaeoclimatol., Palaeoecol. 35, 241-279.

Thunell, R.C., Miao, Q., 1996. Sea surface temperature of the western equatorial Pacific ocean during the Younger Dryas. Quat. Res. 46, 72-77.

Thunell, R.C., Miao, Q., Calvert, S.E., Pedersen, T.F., 1992. Glacial-Holocene biogenic sedimentation patterns in the South China Sea: productivity variations and surface water $p \mathrm{CO}_{2}$. Paleoceanography 7, 143-162.

Thunell, R., Anderson, D., Gellar, D., Miao, Q., 1994. Seasurface temperature estimates for the tropical western Pacific during the last glaciation and their implications for the Pacific Warm Pool. Quat. Res. 41, 255-264.

Tjia, H.D., 1980. The Sunda Shelf, southeast Asia. Z. Geomorphol. 24, 405-427.

Tolderlund, D.S., Bé, A.W.H., 1971. Seasonal distribution of planktonic foraminifera in the western North Atlantic. Micropaleontology 17, 297-329.

Vogelsang, E., 1990. Palaeo-Ozeanographie des Europäischen Nordmeeres an Hand stabiler Kohlenstoff- und Sauerstoffisotope, Ph.D. Thesis, University of Kiel, 137 pp.

Völker, A., Sarnthein, M., Grootes, P.M., Erlenkeuser, H., Laj, C., Mazaud, A., Nadeau, M.J., Schleicher, M., 1998. Correlation of marine ${ }^{14} \mathrm{C}$ ages from the Nordic Seas with the GISP2 isotope record: implications for radiocarbon calibration beyond 25 ka BP. Radiocarbon 40, 517-534.

Wang, L., 1992. The late Quaternary oxygen isotope record and its implications for the ventilation state of the South China Sea. (In Chinese, with English abstr.). In: Ye, Z., Wang, P. (Eds.), Contributions to Late Quaternary Paleoceanography of the South China Sea, Qingdao Ocean. University Press, Qingdao, pp. 195-205.

Wang, L., Wang, P., 1990. Late Quaternary paleoceanography of the South China Sea: glacial/interglacial contrasts in an enclosed basin. Paleoceanography 5, 77-90.

Wang, L., Sarnthein, M., Duplessy, J.-C., Erlenkeuser, H., Jung, S., Pflaumann, U., 1995. Paleo sea surface salinities in the low latitude Atlantic: the $\delta^{18} \mathrm{O}$ record of Globigerinoides ruber (white). Paleoceanography 10, 749-761.

Wang, L., Grothmann, A., Erlenkeuser, H., Sarnthein, M., in prep. Stable isotopes of morphotypes of Globigerinoides ruber (white) and its paleoceanographic implications. Geophys. Res. Lett. (submitted).

Wang, P., 1992. West Pacific marginal seas in the last glaciation: a paleoceanographic comparison. (In Chinese, with English abstr.). In: Ye, Z., Wang, P. (Eds.), Contributions to Late Quaternary Paleoceanography of the South China Sea, Qingdao Ocean. University Press, Qingdao, pp. 308-321.

Wang, P., Wang, L., Bian, Y., Jian, Z., 1995. Late Quaternary paleoceanography of the South China Sea: surface circulation and carbonate cycles. Mar. Geol. 127, 145-166.

Wei, K.-Y., Lee, M.-Y., Duan, W., Chen, C., Wang, C.H., 1998. Paleoceanographic change in the northeastern South China Sea during the last 15000 years. J. Quat. Sci. 13, 55-64.

Wiesner, M.G., Zhen, L., Wong, H.K., Wang, Y., Chen, W., 1996. Fluxes of particulate matter in the South China Sea. In: Ittekkot, V., Schaefer, P., Honjo, S., Depetris, P.J. (Eds.), Particle Flux in the Ocean. Wiley, New York, pp. 293-312.

Williams, D.F., Bé, A.W.H., Fairbanks, R.G., 1981. Seasonal stable isotopic variations in living planktonic foraminifera from Bermuda plankton tows. Palaeogeogr., Palaeoclimatol., Palaeoecol. 33, 71-102.

Winkler, M.G., Wang, P.K., 1993. The late Quaternary vegetation and climate of China. In: Wright, H.E. et al. (Eds.), Global Climates Since the Last Glacial Maximum. Univ. of Minnesota Press, Minneapolis, pp. 221-264.

Winn, K., Sarnthein, M., Erlenkeuser, H., 1991. $\delta^{18}$ O stratigraphy and chronology of Kiel sediment cores from the East Atlantic. Ber.-Rep., Geol.-Palaeontol. Inst. Univ. Kiel 45, 199.

Winn, K., Zheng, L., Erlenkeuser, H., Stoffers, P., 1992. Oxygen/carbon isotopes and paleoproductivity in the South China Sea during the past 110,000 years. In: Xianglong, J., Kudrass, H.R., Pautot, G. (Eds.), Marine Geology and Geophysics of the South China Sea. Proceedings of the Symposium on the Recent Contributions to the Geological History of the South China Sea. China Ocean Press, Hangzhou, pp. 154-166.

Wyrtki, K., 1961. Physical oceanography of the southeast Asian waters. Scientific Results of Marine Investigations of the South China Sea and the Gulf of Thailand 1959-1961. NAGA Rep. 2, Scripps Institution of Oceanography, La Jolla.

Xiao, J., Porter, S.C., An, Z., Kumai, H., Yoshikawa, S., 1995. Grain size of quartz as an indicator of winter monsoon strength on the loess plateau of Central China during the last 130,000 yr. Quat. Res. 43, 22-29.

Zhang, J., Huang, W., Liu, M., 1994. Geochemistry of major 
Chinese river-estuary systems, In: Zhou, D., Liang, Y., Zeng, C. (Eds.), Oceanology of China Seas, Vol. 1. Kluwer, Dordrecht, pp. 179-188.
Zhou, B., Zhao, Q., 1999. Allochthonous ostracods in the South China Sea and their significance in indicating downslope sediment contamination. Mar. Geol. 156, 187-195. 